University of Nebraska - Lincoln

DigitalCommons@University of Nebraska - Lincoln

\title{
Origin and paleoclimatic signifi cance of late Quaternary loess in Nebraska: Evidence from stratigraphy, chronology, sedimentology, and geochemistry
}

\author{
Daniel R. Muhs \\ U.S. Geological Survey, dmuhs@usgs.gov \\ E. Arthur Bettis III \\ University of lowa, art-bettis@uiowa.edu \\ John N. Aleinikoff \\ U.S. Geological Survey \\ John P. McGeehin \\ U.S. Geological Survey \\ Jossh Beann
}

See next page for additional authors

Follow this and additional works at: https://digitalcommons.unl.edu/usgsstaffpub

Part of the Earth Sciences Commons

Muhs, Daniel R.; Bettis, E. Arthur III; Aleinikoff, John N.; McGeehin, John P.; Beann, Jossh; Skipp, Gary; Marshall, Brian D.; Roberts, Helen M.; Johnson, William C.; and Benton, Rachel, "Origin and paleoclimatic signifi cance of late Quaternary loess in Nebraska: Evidence from stratigraphy, chronology, sedimentology, and geochemistry" (2008). USGS Staff -- Published Research. 162.

https://digitalcommons.unl.edu/usgsstaffpub/162

This Article is brought to you for free and open access by the US Geological Survey at DigitalCommons@University of Nebraska - Lincoln. It has been accepted for inclusion in USGS Staff -- Published Research by an authorized administrator of DigitalCommons@University of Nebraska - Lincoln. 


\section{Authors}

Daniel R. Muhs, E. Arthur Bettis III, John N. Aleinikoff, John P. McGeehin, Jossh Beann, Gary Skipp, Brian

D. Marshall, Helen M. Roberts, William C. Johnson, and Rachel Benton 


\title{
Origin and paleoclimatic significance of late Quaternary loess in Nebraska: Evidence from stratigraphy, chronology, sedimentology, and geochemistry
}

\author{
Daniel R. Muhs ${ }^{\dagger}$ \\ U.S. Geological Survey, MS 980, Box 25046, Federal Center, Denver, Colorado 80225, USA \\ E. Arthur Bettis III \\ Department of Geoscience, University of Iowa, Iowa City, Iowa 52242, USA
}

John N. Aleinikoff

U.S. Geological Survey, MS 963, Box 25046, Federal Center, Denver, Colorado 80225, USA

John P. McGeehin

U.S. Geological Survey, MS 926A, National Center, Reston, Virginia 20192, USA

Jossh Beann

Gary Skipp

U.S. Geological Survey, MS 980, Box 25046, Federal Center, Denver, Colorado 80225 USA

Brian D. Marshall

U.S. Geological Survey, MS 963, Box 25046, Federal Center, Denver, Colorado 80225 USA

Helen M. Roberts

Institute of Geography and Earth Sciences, University of Wales, Aberystwyth, Wales SY23 3DB, UK

William C. Johnson

Department of Geography, University of Kansas, Lawrence, Kansas 66045, USA

Rachel Benton

U.S. National Park Service, Badlands National Park, 25216 Ben Reifel Road, P.O. Box 6, Interior, South Dakota 57750, USA

\begin{abstract}
Loess is one of the most extensive surficial geologic deposits in midcontinental North America, particularly in the central Great Plains region of Nebraska. Last-glacial-age loess (Peoria Loess) reaches its greatest known thickness in the world in this area. New stratigraphic, geochronologic, mineralogic, and geochemical data yield information about the age and provenance of Peoria Loess, as well as evaluation of recent climate models.

Sixteen new radiocarbon ages and recently acquired optically stimulated luminescence ages indicate that Peoria Loess deposition in Nebraska occurred between ca. 25,000 cal yr B.P. and ca. 13,000 cal yr B.P. After ca. 13,000 cal yr B.P. a period of pedogenesis began, represented by the dark, prominent Brady Soil. At some localities, further loess
\end{abstract}

E-mail: dmuhs@usgs.gov deposition was minimal. At other localities, sometime after ca. 11,000 cal yr B.P., there were additional episodes of loess deposition (Bignell Loess) intermittently throughout the Holocene.

The spatial variability of particle size abundances in Peoria Loess shows a northwest-to-southeast fining in Nebraska, consistent with maps of previous workers that show a northwest-to-southeast thinning of loess. These observations indicate that paleowinds that deposited the loess were from the west or northwest and that the source or sources of Peoria Loess lay to the west or northwest.

New mineralogical and geochemical data indicate that the most important sources of loess were likely Tertiary siltstones of the White River and Arikaree Groups, silt facies of Pliocene eolian sediments, and small contributions from Pierre Shale. It is likely that fine-grained silts were transported episodically through the Nebraska Sand Hills from
Tertiary and Cretaceous bedrock sources to the north, in agreement with a model presented recently. The identification of Tertiary siltstones and silts as the primary sources of loess is consistent with isotopic data presented in a companion paper. Contributions of glaciogenic silt from the Platte and Missouri Rivers were limited to loess zones close to the valleys of those drainages. An earlier computer-based model of global dust generation during the last glacial period did not identify the Great Plains of North America as a significant source of nonglaciogenic eolian silt. However, a refined version of this model does simulate this region as a significant nonglacial dust source during the last glacial period, in good agreement with the results presented here.

Keywords: Peoria Loess, Nebraska, Great Plains, last glacial period, stratigraphy, geochemistry, provenance, paleoclimate.

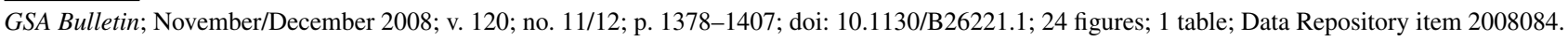




\section{INTRODUCTION}

Loess is an important archive of Quaternary climate change and may provide one of the most complete terrestrial records of interglacialglacial cycles (Porter, 2001; Muhs and Bettis, 2003). Because loess is eolian, it also is one of the few geologic deposits that yield direct records of atmospheric circulation and past wind directions.

Loess is extensive in the Midcontinent of North America, and Peoria Loess, of last glacial age, reaches its maximum known thickness in the state of Nebraska (Fig. 1). Despite the importance of Peoria Loess as a surficial deposit and soil parent material in this region, little is known of its provenance, which is potentially of paleoclimatic significance. Unlike Peoria Loess found farther to the east in Iowa, Illinois,
Wisconsin, Indiana, and Ohio, Peoria Loess in the Great Plains is not close to the margins of the Laurentide ice sheet (Fig. 1). In the eastern parts of the North American Midcontinent, loess has traditionally been linked to glacial sources (Grimley, 2000). However, an obvious glacialsource linkage is lacking in Nebraska.

Although many workers have speculated for decades about the origin of Peoria Loess in Nebraska (reviewed below), more recently Mason (2001) proposed two hypotheses for its origin, which we evaluate herein. To test these hypotheses, we present new data on the stratigraphy, sedimentology, geochronology, mineralogy, and geochemistry of Peoria Loess in Nebraska. We also compare our results with a recent dust-cycle simulation model presented by Mahowald et al. (2006) and a recent climate model presented by Bromwich et al. (2005). Our

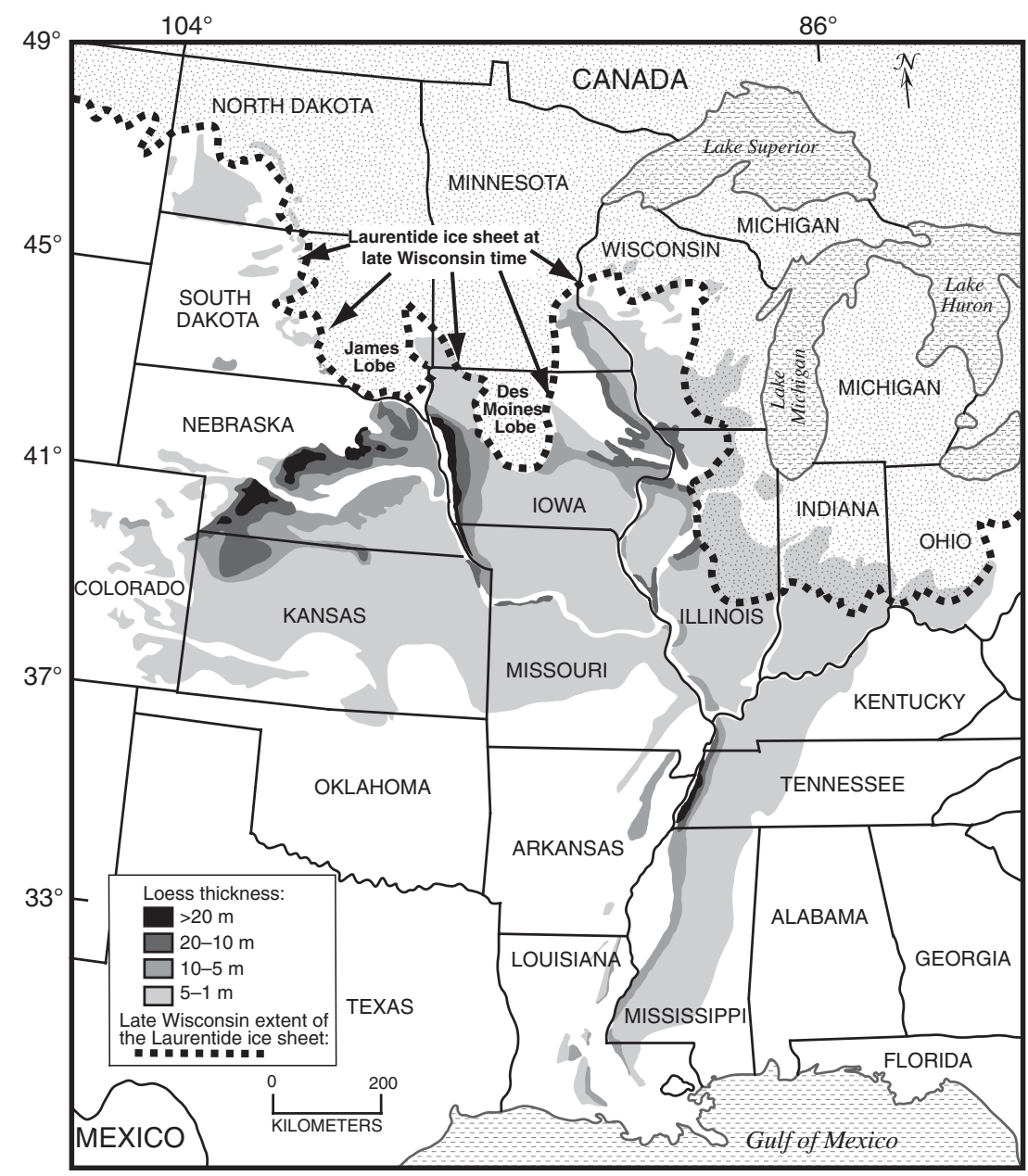

Figure 1. Distribution and thickness of loess, mostly Peoria Loess of last glacial age, in central North America. Also shown (dashed line) is the maximum late Wisconsin extent of the Laurentide ice sheet. Loess thickness and distribution taken from compilation in Bettis et al. (2003a) and sources therein; Laurentide ice sheet extent generalized from Fullerton et al. (2003, 2004). results complement isotopic studies contained in a companion paper (Aleinikoff et al., 2008).

\section{ORIGIN OF LOESS IN NEBRASKA}

Loess is widespread in Nebraska and is part of the large belt of late Quaternary loess that covers much of the North American Midcontinent (Figs. 1 and 2). Three late Quaternary loess units, from oldest to youngest, the Gilman Canyon Formation, Peoria Loess, and Bignell Loess, have been recognized in Nebraska and other Great Plains states for six decades (Schultz and Stout, 1945; Condra et al., 1947; Frye and Leonard, 1951; Swinehart et al., 1994a). The Gilman Canyon Formation is thin (usually less than $2 \mathrm{~m}$ ), typically has one or more paleosols with organic-rich soil A horizons developed within it, and is extensively burrowed (Johnson et al., 2007). Peoria Loess overlies the Gilman Canyon Formation and is the thickest and spatially most extensive of the Great Plains loess units. Peoria Loess is as thick as $47 \mathrm{~m}$ in the western part of Nebraska and is less than $4 \mathrm{~m}$ thick (or absent) in the southeastern part of the state (Mason, 2001). In many places, Peoria Loess is the youngest eolian silt identifiable in the field. At other localities a buried soil with a dark A horizon, referred to as the Brady Soil (Schultz and Stout, 1945), is developed in the upper part of Peoria Loess and separates this unit from the overlying Bignell Loess. Bignell Loess is as thick as $\sim 6 \mathrm{~m}$ but is typically $1-3 \mathrm{~m}$ thick (Mason et al., 2003a; Jacobs and Mason, 2007; Miao et al., 2005).

In eastern Colorado, thin, younger loess also overlies Peoria Loess. Based on radiocarbon ages, Muhs et al. (1999) suggested that this unit could be slightly older than Bignell Loess at its type locality (Bignell Hill, Nebraska), and they informally designated the younger loess in Colorado as "Beecher Loess." However, Johnson and Willey (2000) later presented a larger age range for the Brady Soil in Nebraska and Kansas. Hence, we consider that "Beecher Loess" is equivalent to Bignell Loess of Nebraska and recommend that the informal term be abandoned.

During the past decade, there have been a number of efforts to refine the geochronology of late Quaternary loess deposition on the Great Plains. Radiocarbon, thermoluminescence (TL), and optically stimulated luminescence (OSL) ages indicate that the Gilman Canyon Formation dates to one or more interstadial periods in the late Quaternary, from ca. 40,000 to ca. $25,000{ }^{14} \mathrm{C}$ yr B.P. (see summary in Johnson et al., 2007). Peoria Loess was deposited during the last glacial period (ca. 25,000 to ca. 12,000 ${ }^{14} \mathrm{C}$ yr B.P.), and Bignell Loess is of Holocene $\left(<10,000{ }^{14}\right.$ C yr B.P.) age (Pye et al., 1995; Maat 


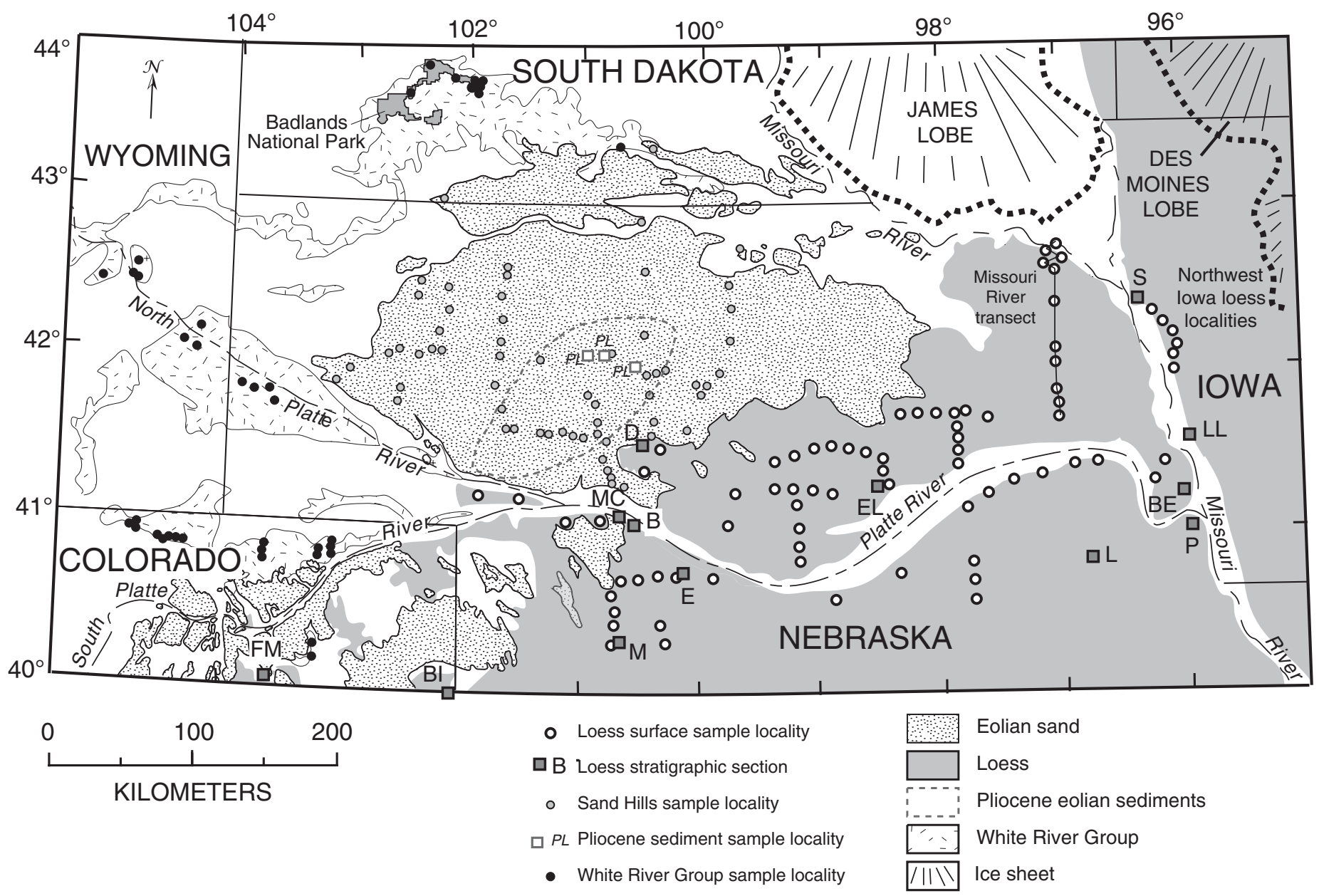

Figure 2. Distribution of loess, Holocene eolian sand of the Nebraska Sand Hills, Pliocene eolian sediments, and the Tertiary White River Group in Nebraska and adjacent states; sample localities; locations of loess sections; and other localities referred to. Note that loess in the northeastern part of the map area is beneath till of the Des Moines lobe. FM-Fort Morgan; BI-Beecher Island; M-McCook; MCMoran Canyon; B-Bignell Hill; D-Devil's Den; E-Eustis; EL_Elba; L-Lincoln; BE-Bellevue; P-Plattsmouth; LL-Loveland; S-Sioux City (Sergeant Bluff). Loess and eolian sand distribution based on Swinehart et al. (1994a), Muhs et al. (1996, 1999), and Mason (2001); Pliocene eolian sand distribution from Myers (1993) and Swinehart et al. (1994b); extent of White River Group taken from Scott (1978), Burchett (1986), and Martin et al. (2004).

and Johnson, 1996; Muhs et al., 1999; Johnson and Willey, 2000; Mason and Kuzila, 2000; Mason et al., 2003a; Roberts et al., 2003; Miao et al., 2005; Rousseau et al., 2007).

Although the origin of Peoria Loess in the Great Plains of Nebraska, Kansas, and Colorado has been studied for more than six decades, at present there is no consensus on its genesis. As mentioned above, Peoria Loess in the Great Plains has no clear link to outwash of the Laurentide ice sheet, except possibly in that part of Nebraska adjacent to the Missouri River. Previous workers proposed a variety of sources for loess in the Great Plains, including Platte River alluvium (including glacial outwash from the Rocky Mountains); glacial outwash from the Missouri River; sediments from the Tertiary Ogallala, Arikaree, and White River Groups; and sediment from the Nebraska Sand Hills or other dune fields (Lugn, 1939, 1968; Bryan, 1945; Condra et al., 1947; Swineford and Frye, 1951; Reed, 1968; Wright, 1970; Flint, 1971; Smalley, 1995; Winspear and Pye, 1995; Aleinikoff et al., 1999; Muhs et al., 1999).

More recently, Mason (2001) presented two new hypotheses concerning the origin of Peoria Loess in Nebraska. He infers westerly or northwesterly paleowinds, based on his new compilation of loess thickness data. Using preliminary isotopic data presented by Aleinikoff et al. (1998), both of Mason's (2001) models also assume that an important initial, or original, source material for the Peoria Loess in Nebraska is siltstone of the White River Group, which crops out to the north, northwest, and west of the Nebraska Sand Hills (Fig. 2).
In the first of these models, Mason (2001) proposes entrainment of White River Group sediments by wind, either directly from weathered parts of the rock itself or from stream and river valleys that drain the unit. Although coarse silt particles from these sources would likely be kept in suspension only for short distances, longer-distance transport could be possible by eolian re-entrainment through an active Nebraska Sand Hills. In this sequence of events, Mason (2001) envisions little or no net accumulation of eolian silt in the Nebraska Sand Hills. Instead, he views the dune field as a "surface of transport," where a succession of short-distance, low-suspension transport events could have taken place. Ultimately, therefore, even relatively coarse-grained silt and fine-grained sand could undergo a cumulative transport distance 
Origin of loess in Nebraska

TABLE 1. RADIOCARBON AGES OF LATE QUATERNARY LOESS FROM NEBRASKA ${ }^{\dagger}$

\begin{tabular}{|c|c|c|c|c|c|c|c|c|c|}
\hline $\begin{array}{l}\text { Laboratory } \\
\text { number }\end{array}$ & $\begin{array}{c}\mathrm{LLNL}^{\ddagger} \text { or UAZ } \\
\text { number }\end{array}$ & $\begin{array}{c}\text { Field } \\
\text { number }\end{array}$ & Locality & Unit & Material & $\begin{array}{c}{ }^{14} \mathrm{C} \text { age } \\
(\mathrm{yr})\end{array}$ & $\begin{array}{c}\text { Error } \\
( \pm 1 \text { s.d. })\end{array}$ & $\begin{array}{c}\text { Age } \\
\text { (yr B.P.) }\end{array}$ & $\begin{array}{c}\text { Error } \\
( \pm 1 \text { s.d.) }\end{array}$ \\
\hline WW2743 & CAMS-63616 & $\begin{array}{l}\text { NE 530-1 } \\
(0.5 \mathrm{mg} \mathrm{C})\end{array}$ & McCook & Gilman Canyon paleosol, upper & Humic acid & 26,420 & 200 & 31,459 & 175 \\
\hline WW2744 & CAMS-63617 & $\begin{array}{l}\text { NE } 530-2 \\
(0.4 \mathrm{mg} \mathrm{C})\end{array}$ & McCook & Gilman Canyon paleosol, middle & Humic acid & 26,860 & 210 & 31,812 & 184 \\
\hline WW2745 & CAMS-63618 & NE 530-3 & McCook & Gilman Canyon paleosol, lower & Humic acid & 32,740 & 250 & 37,716 & 615 \\
\hline WW4046 & CAMS-89217 & MC-22 & Moran Canyon & Late Holocene paleosol & Humic acid & 1165 & 45 & 1076 & 64 \\
\hline WW4047 & CAMS-89218 & MC-26 & Moran Canyon & Holocene paleosol, upper & Humic acid & 4155 & 35 & 4714 & 82 \\
\hline WW4048 & CAMS-89219 & MC-27 & Moran Canyon & Holocene paleosol, lower & Humic acid & 5580 & 35 & 6357 & 40 \\
\hline WW4049 & CAMS-89220 & MC-30 & Moran Canyon & Brady Soil, upper & Humic acid & 9550 & 35 & 10,869 & 121 \\
\hline WW4050 & CAMS-89221 & MC-31 & Moran Canyon & Brady Soil, lower & Humic acid & 10,600 & 35 & 12,599 & 38 \\
\hline NSRL-2954 & CAMS-26399 & $\mathrm{BH}-5$ & Bignell Hill & Modern soil, upper & Humic acid & 1360 & 60 & 1286 & 40 \\
\hline NSRL-2955 & CAMS-26400 & $\mathrm{BH}-6$ & Bignell Hill & Modern soil, lower & Humic acid & 1400 & 50 & 1308 & 29 \\
\hline NSRL-2804 & CAMS-24344 & $\mathrm{BH}-1$ & Bignell Hill & Brady Soil, upper & Humic acid & 10,070 & 60 & 11,631 & 158 \\
\hline NSRL-2805 & CAMS-24345 & $\mathrm{BH}-2$ & Bignell Hill & Brady Soil, lower & Humic acid & 10,490 & 60 & 12,483 & 106 \\
\hline NSRL-2956 & CAMS-26401 & $\mathrm{BH}-7$ & Bignell Hill & Gilman Canyon, upper paleosol & Humic acid & 30,770 & 210 & 35,658 & 252 \\
\hline NSRL-2806 & CAMS-24346 & $\mathrm{BH}-3$ & Bignell Hill & Gilman Canyon, lower paleosol & Humic acid & 40,600 & 1100 & 44,609 & 836 \\
\hline WW4053 & CAMS-89224 & DD-1 & Devil's Den & Holocene paleosol & Humic acid & 1405 & 35 & 1309 & 19 \\
\hline WW4054 & CAMS-89225 & DD-2 & Devil's Den & Brady Soil & Humic acid & 10,105 & 35 & 11,723 & 92 \\
\hline WW4055 & AA-53370 & DD-3 & Devil's Den & Gilman Canyon, upper paleosol & Humic acid & 22,680 & 160 & 27,177 & 189 \\
\hline WW4056 & AA-53371 & DD-4 & Devil's Den & Gilman Canyon, lower paleosol & Humic acid & 27,270 & 270 & 32,141 & 230 \\
\hline WW4051 & CAMS-89222 & Eustis-1 & Eustis & Gilman Canyon/Peoria mixing zone & Humic acid & 23,870 & 100 & 28,433 & 136 \\
\hline WW4052 & CAMS-89223 & Eustis-2 & Eustis & Gilman Canyon paleosol & Humic acid & 28,100 & 200 & 32,808 & 180 \\
\hline WW2099 & CAMS-51545 & EL-12A & Elba & Gilman Canyon paleosol, upper & Humic acid & 24,940 & 90 & 29,930 & 334 \\
\hline WW2100 & CAMS-51546 & EL-13A & Elba & Gilman Canyon paleosol, lower & Humic acid & 24,000 & 80 & 28,570 & 118 \\
\hline NSRL-1479 & CAMS-10188 & & Bellevue & Lower Peoria, $38 \mathrm{~cm}$ above contact & Humic acid & 22,210 & 170 & 26,681 & 193 \\
\hline NSRL-1478 & CAMS-10187 & & Bellevue & Lower Peoria, $36 \mathrm{~cm}$ above contact & Humic acid & 21,810 & 160 & 26,260 & 177 \\
\hline NSRL-1480 & CAMS-10186 & & Bellevue & Lower Peoria, $32 \mathrm{~cm}$ above contact & Humic acid & 22,040 & 160 & 26,501 & 181 \\
\hline NSRL-1481 & CAMS-10190 & & Bellevue & Gilman Canyon paleosol & Charcoal & 25,340 & 260 & 30,538 & 341 \\
\hline
\end{tabular}

${ }^{\dagger}$ All ages are from this study except for Bignell Hill (Muhs et al., 1999) and Bellevue (Mandel and Bettis, 1995), but both sets are recalibrated here.

‡Lawrence Livermore National Laboratory.

¿University of Arizona.

"Calibrated" ages of all radiocarbon ages are from Fairbanks et al. (2005). Error estimates for "calibrated" ages from Fairbanks et al. (2005) are considered to be unrealistically precise (see text for discussion).

of hundreds of kilometers before deposition. Mason et al. (1999) had earlier hypothesized the importance of actively moving sand in the Nebraska Sand Hills for entrainment of silt particles and eventual deposition as loess to the southeast of the dune field in Nebraska. Mason et al. (2003a) applied this model to explain the origin of Holocene Bignell Loess in Nebraska.

Mason's (2001) second hypothesis requires that silt-sized particles from the White River Group were initially transported to central Nebraska prior to Peoria Loess deposition, perhaps even in the Pliocene. Swinehart et al. (1985) show that Pliocene sediments are extensive in Nebraska and underlie parts of the Sand Hills region, to the northwest of Peoria Loess in the area. Some of these Pliocene sediments are part of an eolian sand sheet (Myers, 1993; Swinehart et al., 1994b) and are silt-rich in places (Fig. 2). If the White River Group provided the sediments for the fine-grained facies of the Pliocene deposits, then re-entrainment of Pliocene silts by wind during the last glacial period would have required a shorter distance of transport to the southeast to form the extensive Peoria Loess belt in Nebraska. Although not stated explicitly by Mason (2001), this model requires that silt-rich Pliocene sediments must have been exposed at the surface during the last glacial period, when Peoria Loess was accumulating in Nebraska. Because Holocene dune sand of the Nebraska Sand Hills presently overlies most of the silt-rich Pliocene sediment (Fig. 2), this second model requires that (1) the Nebraska Sand Hills did not exist in its present form during the last glacial period, and/or (2) Pliocene sediments provided the source sediment for both the Nebraska Sand Hills and Peoria Loess (J. Mason, May 2007, written commun.).

\section{METHODS}

Peoria Loess from shallow depths in Nebraska was examined and collected from road cuts, natural exposures, and auger borings at 75 localities for particle size, mineralogy, and geochemistry (Fig. 2). Potential bedrock sources for loess were also collected, including Pierre Shale, the White River Group, the Arikaree Group, and the silt facies of eolian sheet-sand sediments (Pliocene), from localities in Colorado, Wyoming, Nebraska, and South Dakota. Pierre Shale is a gray, bentonitic shale, with some siltstone, and is of Cretaceous age. The White River Group is white to light brown, mostly volcaniclastic siltstone, with some claystone and sandstone, of Oligocene to Eocene age. The Arikaree Group is siltstone and sandstone, mostly volcaniclastic, of Miocene and Oligocene age. Samples of eolian sand from $\sim 60$ localities within the Nebraska Sand Hills, studied previously by Muhs et al. (1997,
2000), were analyzed for mineralogy and geochemistry. Fine-grained overbank sediments from the modern floodplain of the South Platte River were collected in Colorado at localities identical to those in Muhs et al. (1999). Peoria Loess stratigraphy was studied and samples collected at nine sections across Nebraska and two new sections in adjacent Iowa and Colorado (Fig. 2).

At several loess sections in Nebraska, samples of paleosols were collected for radiocarbon dating. Radiocarbon ages were determined on humic acid extractions from organic matter in paleosols, following methods outlined by McGeehin et al. (2001). Radiocarbon abundance was measured by accelerator mass spectrometry (AMS) at Lawrence Livermore National Laboratory. Radiocarbon ages were converted to approximate calendar-year ages (Table 1), using Fairbanks et al. (2005). We note, however, that this calibration curve, especially for calibrated ages $>26,000 \mathrm{yr}$, has not received universal acceptance in the geochronology community. Additionally, the calibrated ages are given with a 1 sigma error, which we feel is too precise given the sample materials and processing employed. Hence, we consider these converted ages as estimates and refer to them in this document without error estimates.

Particle size analysis of loess and paleosols was conducted by a combination of sieve and 
pipette methods (see GSA Data Repository ${ }^{1}$ ). Samples were pretreated with $\mathrm{H}_{2} \mathrm{O}_{2}$ to destroy organic matter, $\mathrm{HCl}$ to remove carbonates, and Na-hexametaphosphate to enhance dispersion. Sands (particles with diameters $>53 \mu \mathrm{m}$ ) were separated from silts and clays by wet-sieving; abundances of coarse silts $(53-20 \mu \mathrm{m})$, fine silts (20-2 $\mu \mathrm{m})$, and clays $(<2 \mu \mathrm{m})$ were determined by settling and pipette analysis. Laboratory precision for pipette analysis was routinely monitored with each suite of sample runs by analysis of an Iowa loess standard maintained by the Department of Agronomy, Iowa State University.

All loess samples collected for mineralogy and geochemistry were taken below the primary zone of pedogenesis, usually at depths of $\sim 2-3 \mathrm{~m}$. The relative abundance of minerals in powdered samples was determined by measuring X-ray-diffraction (XRD) peak intensities (heights) as follows: quartz, $20.8^{\circ}$; K-feldspar, $27.4^{\circ}$; plagioclase, $27.8^{\circ}$; calcite, $29.4^{\circ}$; dolomite, $30.9^{\circ}$ (all 2 theta). Clay mineralogy by XRD was determined on selected samples on oriented air-dry, glycolated, and heat-treated slides $\left(550{ }^{\circ} \mathrm{C}\right.$ for $\left.1 \mathrm{~h}\right)$

Chemical analyses of loess were conducted on bulk samples (i.e., no pretreatments other than pulverization) and therefore include carbonates. For chemical analyses of potential loess source materials with significant amounts of gravel and coarse to medium sand, samples were treated with $\mathrm{H}_{2} \mathrm{O}_{2}$ to remove organic material and Nahexametaphosphate for dispersal of fine grains. Dispersed samples were then passed through a $125-\mu \mathrm{m}$ sieve to remove all gravel and all but the finest sand fraction; material passing through the sieve was then pulverized and analyzed for chemical composition. The finest sand fraction was retained for analysis because particle size analyses (discussed below) indicate that Peoria Loess in Nebraska has significant amounts of fine sand. This procedure was applied to South Platte River sediments, tills, Pliocene eolian sediments, and silt-rich sediments of the Arikaree Group. Samples of the Nebraska Sand Hills, the White River Group siltstone, and Pierre Shale contain little or no gravel or coarse sand and were analyzed as bulk sediments. Major element geochemistry for Peoria Loess in Nebraska was determined by wavelength-dispersive X-ray fluorescence (WD$\mathrm{XRF}$ ). WD-XRF was also used for trace element geochemistry in our comparison of "northern" versus "southern" Peoria Loess in Nebraska. For provenance studies we also utilized certain

${ }^{1}$ GSA Data Repository Item 2008084, Peoria Loess and sources-geochemical and particle size data, is available at www.geosociety.org/pubs/ ft2008.htm. Requests may also be sent to editing@ geosociety.org key trace elements ( $\mathrm{Rb}$ and $\mathrm{Nb})$, and the major elements for which they substitute $(\mathrm{K}$ and $\mathrm{Ti}$, respectively), in order to calculate $\mathrm{K} / \mathrm{Rb}$ and $\mathrm{Ti} /$ $\mathrm{Nb}$ values. These four elements were measured by energy-dispersive X-ray fluorescence (ED$\mathrm{XRF}$ ). Estimates of carbonate content were made on selected samples using a Chittick apparatus, following the method outlined by Dreimanis (1962). Dissolution was accomplished using 6N $\mathrm{HCl}$ and a 5 min reaction time, which measures calcite but not dolomite.

\section{STRATIGRAPHY AND GEOCHRONOLOGY OF LOESS IN NEBRASKA}

Sixteen new AMS radiocarbon ages, presented here, combined with previously reported radiocarbon ages (Mandel and Bettis, 1995; Muhs et al., 1999) and OSL ages recently reported by Roberts et al. (2003) and Mason et al. (2003a), have allowed us to infer the chronology of loess deposition at sections we studied in Nebraska (Table 1; Figs. 3-10). The mid-Wisconsin interstadial complex, represented by the Gilman Canyon Formation loesses and paleosols, apparently was a period of some complexity, with alternating episodes of loess or eolian sand deposition and soil formation (see also Johnson et al., 2007). Ages of the uppermost Gilman Canyon Formation paleosols at Bignell Hill, Devil's Den, Eustis, McCook, and Elba give maximum-limiting ages for the initiation of Peoria Loess deposition in western and central Nebraska (Figs. 3-8). The youngest radiocarbon ages of the Gilman Canyon Formation differ from section to section, but it is not clear whether this is a time-transgressive pattern, the approximate nature of humic acid radiocarbon ages, or erosion of parts of some sections. At Bignell Hill and McCook the uppermost parts of the Gilman Canyon Formation paleosols have ages of 35,000-31,000 cal yr B.P. (Table 1). At Eustis, Devil's Den, and Elba, maximum-limiting ages are ca. 30,000-27,000 cal yr B.P. At Bellevue, near Omaha, humic acid extractions from organic-rich zones within the lowermost Peoria Loess indicate that eolian deposition in eastern Nebraska was in progress sometime after ca. 26,000 cal yr B.P. (Fig. 10; see also Mandel and Bettis, 1995). We infer that the organic-rich zones at Bellevue are eroded soil A horizons, derived from higher slope positions and moved downslope by solifluction. Thus, the organicrich zones are interpreted to be somewhat older than the enclosing loess.

OSL ages reported by Roberts et al. (2003) are consistent with both new and previously reported radiocarbon ages for the time of initial Peoria Loess deposition. In western Nebraska,
Roberts et al. (2003) report that the earliest Peoria Loess deposition was in progress by ca. 25,000 cal yr B.P. at Bignell Hill, ca. 20,700 cal yr B.P. at Eustis, and ca. 18,400 cal yr B.P. at Devil's Den (Figs. 3, 4, 7). All these ages postdate the youngest radiocarbon ages of the underlying Gilman Canyon Formation paleosols at each locality. OSL ages at Eustis (Roberts et al., 2003) agree reasonably well with new OSL data for this section reported by Rousseau et al. (2007).

Peoria Loess deposition ended sometime between ca. 14,000 and 12,000 cal yr B.P., based on the uppermost Peoria Loess OSL ages reported by Roberts et al. (2003) and radiocarbon ages of the Brady Soil at Bignell Hill, Devil's Den, and Moran Canyon (Table 1; Figs. 3-6). Our ages of the lowermost Brady Soil (ca. 13,800 to ca. 11,700 cal yr B.P.), minimum times for the termination of Peoria Loess deposition, agree closely with those reported for Bignell Hill, Devil's Den, and other localities by Johnson and Willey (2000), Mason et al. (2003a), and Miao et al. (2005, 2007). At Bignell Hill, Devil's Den, and Moran Canyon (Figs. 3-6) the Brady Soil is well expressed morphologically, with an $\mathrm{A} / \mathrm{Bk} 1 / \mathrm{Bk} 2 / \mathrm{C}$ horizon sequence (for detailed descriptions and interpretation of the Brady Soil at other localities, see Jacobs and Mason, 2007). Modern surface soils at these localities are not as well developed as the Brady Soil. At other localities, such as McCook, Eustis, Elba, Lincoln, and Bellevue, the Bignell Loess and the Brady Soil are absent, and the modern soil is developed in the uppermost Peoria Loess.

After formation of the Brady Soil, renewed loess deposition occurred in Nebraska during the Holocene. At Moran Canyon, there were three episodes of loess deposition following formation of the Brady Soil (Figs. 5, 6), at ca. $11,000-6300,4700-1100$, and 1100-0 cal yr B.P. These bracketing radiocarbon ages are in excellent agreement with OSL ages of the loess itself of ca. 8800, ca. 2600, and ca. $680 \mathrm{cal} \mathrm{yr}$ B.P., respectively (Mason et al., 2003a). At Devil's Den, there were at least two episodes of Holocene loess deposition, between ca. 11,700 and $1300 \mathrm{cal} \mathrm{yr} \mathrm{B.P.} \mathrm{and} \mathrm{since} 1300 \mathrm{cal} \mathrm{yr} \mathrm{B.P.}$ (Fig. 4). In contrast, only one episode of Holocene loess deposition is found at Bignell Hill (Fig. 3). In southwestern Nebraska, Mason et al. (2003a) and Miao et al. (2005) show that Holocene loess is thickest near the Nebraska Sand Hills and smaller dune fields found to the southwest. Bignell Loess is thinnest or is not apparent at localities far to the southeast of these dunes. Jacobs and Mason (2007) propose that the expression of distal Holocene loess in Nebraska is silty A horizons over clayey B horizons in 


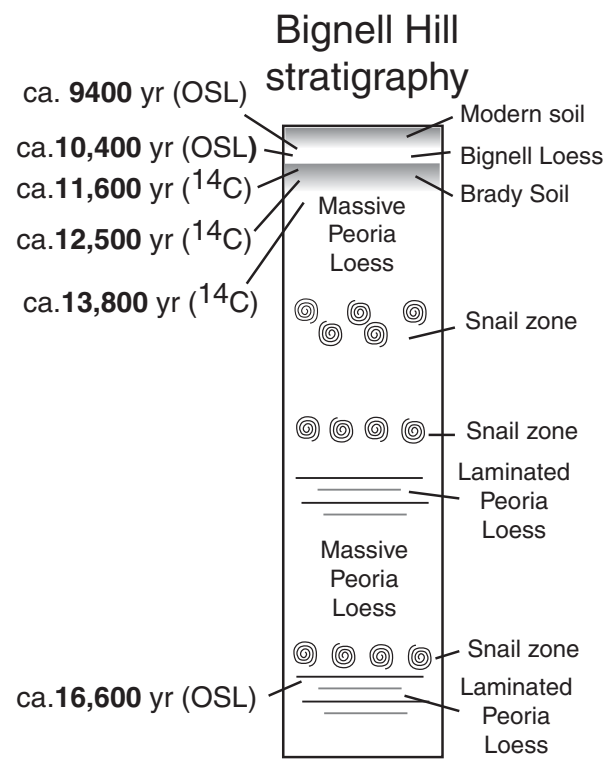

(section covered)

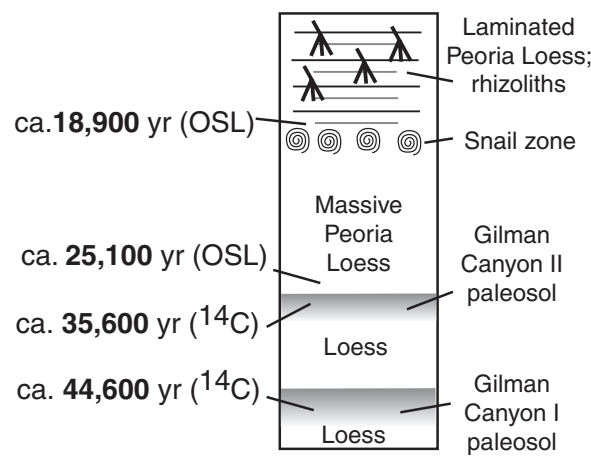

modern soils; the latter are former Brady Soil A horizons. Their observations agree with those made in the present study, as no Holocene loess is visible in the field at the Eustis, McCook, Elba, Lincoln, Bellevue, and Plattsmouth localities, which are farthest from any dune fields.

\section{PEORIA LOESS SEDIMENTOLOGY}

Peoria Loess, collected in the upper few meters at $\sim 75$ localities across Nebraska (Fig. 2), has particle size distributions (shown in Fig. 11 on a sand-free basis) that are typical of loess found in other regions. On a sand-inclusive basis, all but a few samples are $>60 \%$ silt, although most are $<80 \%$. The coarse silt content $(53-20 \mu \mathrm{m})$ for most samples ranges from $45 \%$ to $65 \%$, and the fine silt content $(20-2 \mu \mathrm{m})$ for most samples ranges from $15 \%$ to $30 \%$. The clay content $(<2$ $\mu \mathrm{m})$ is in all cases $<30 \%$, and most samples

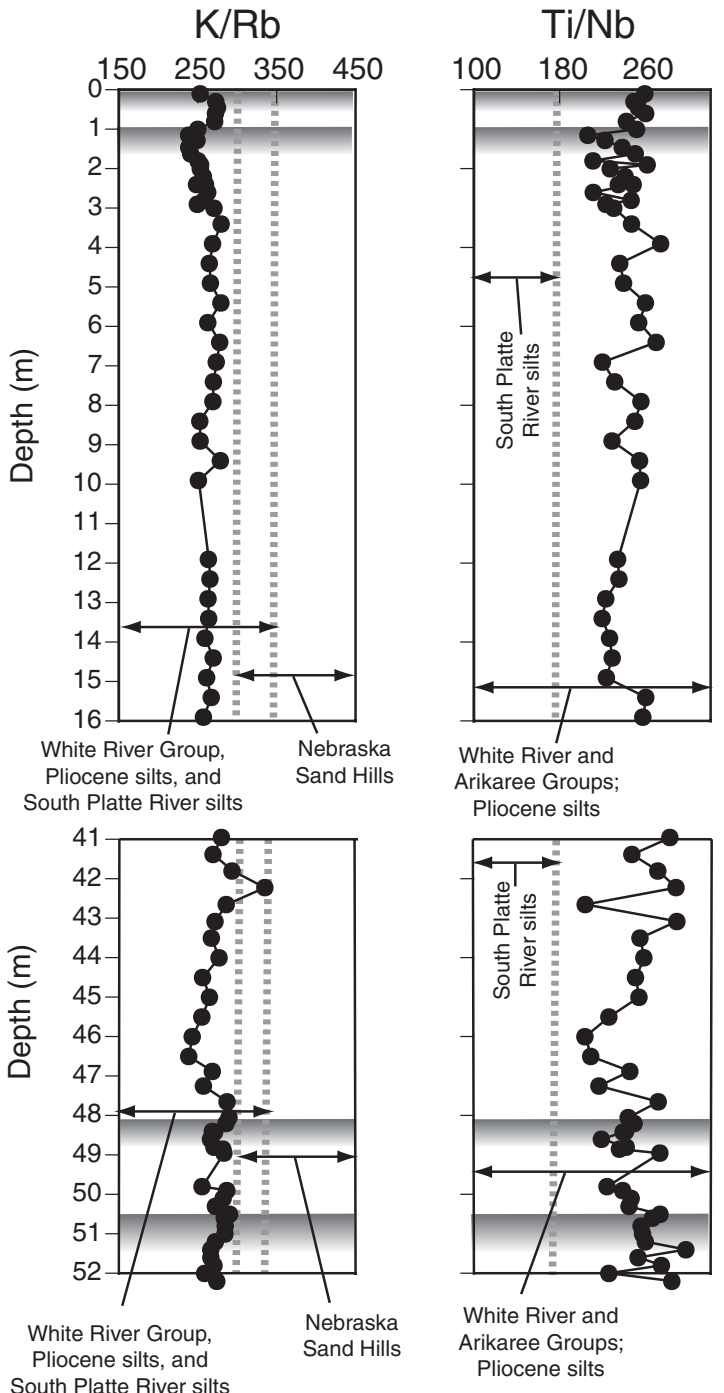

Figure 3. Stratigraphy, optically stimulated luminescence (OSL) and calibrated radiocarbon ages (yr B.P.), K/Rb, and $\mathrm{Ti} / \mathrm{Nb}$ at Bignell Hill, Nebraska. Radiocarbon ages are from Muhs et al. (1999), OSL ages for Peoria Loess are from Roberts et al. (2003), and OSL ages for Bignell Loess are from Mason et al. (2003a). Also shown are ranges of $K / \mathrm{Rb}$ and $\mathrm{Ti} / \mathrm{Nb}$ for various loess sources. All geochemical data are from this study. Note that primary loess is not exposed from $\sim 16-41 \mathrm{~m}$, in contrast to Feng and Khosbayar (2004). have $<20 \%$. The sand content $(>53 \mu \mathrm{m})$ for most samples is $<30 \%$.

Maps of particle size class abundance, handcontoured from individual sample localities, show that the sedimentology of Peoria Loess in Nebraska has a systematic geographic variation. The sand content decreases to the southeast, away from the Nebraska Sand Hills (Fig. 12A). In contrast to sand, fine silt and clay show increases to the southeast of the Nebraska Sand Hills (Figs. 12B and 12C). The particle size trends are consistent with data from Mason et al. (2003b) and parallel the loess thickness contours of Swinehart et al. (1994a) and Mason (2001).

All three particle size maps display anomalous points with regard to the contoured values (Figs. 12A-12C). Positive anomalies-localities with contents higher than the contoured values - are found mainly on the sand content map only along the Platte River in eastern Nebraska.
On the maps showing fine silt and clay contents, anomalies are mostly negative and many of them are the same localities as those that show positive sand content anomalies. The proximity of these anomalous localities to the Platte River suggests a local input of coarse grains from the river valley that is superimposed on a regional northwest-to-southeast fining trend. This interpretation is consistent with anomalous thickness measurements adjacent to the Platte River (Mason, 2001).

Detailed particle size analyses of two sections (Bignell Hill and Eustis) illustrate broad similarity in particle size over the course of Peoria Loess deposition. At Bignell Hill, sand content in Peoria Loess varies between $20 \%$ and $\sim 52 \%$, although most samples are between $\sim 30 \%$ and $\sim 40 \%$ (Fig. 13A). This size distribution is consistent with the overall spatial trend that shows Bignell Hill approximately at the 


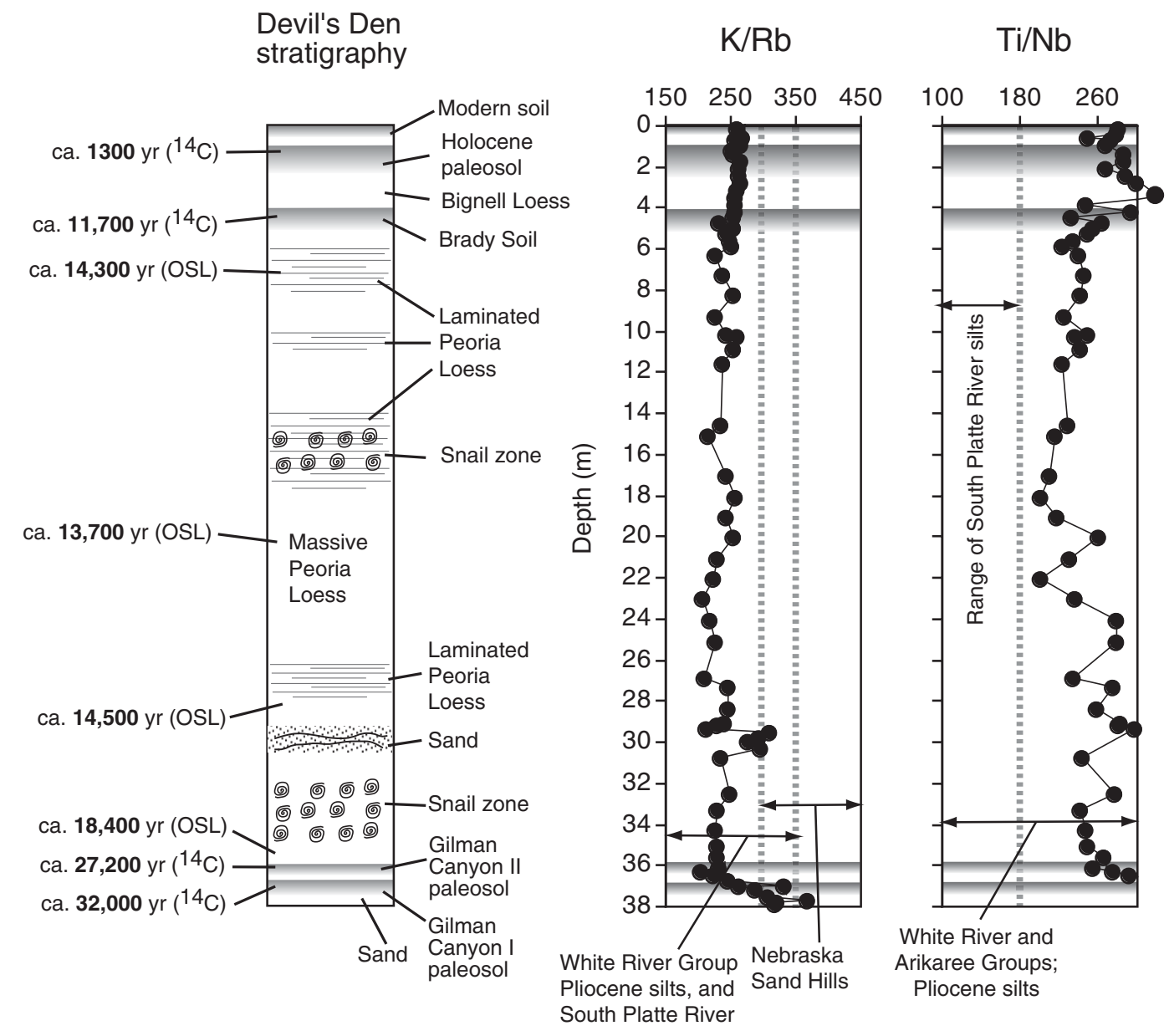

Figure 4. Stratigraphy, OSL and calibrated radiocarbon ages (yr B.P.), K/Rb, and Ti/Nb at Devil's Den, Nebraska, and in various loess sources. Radiocarbon ages are from this study, and OSL ages for Peoria Loess are from Roberts et al. (2003).

Moran Canyon stratigraphy

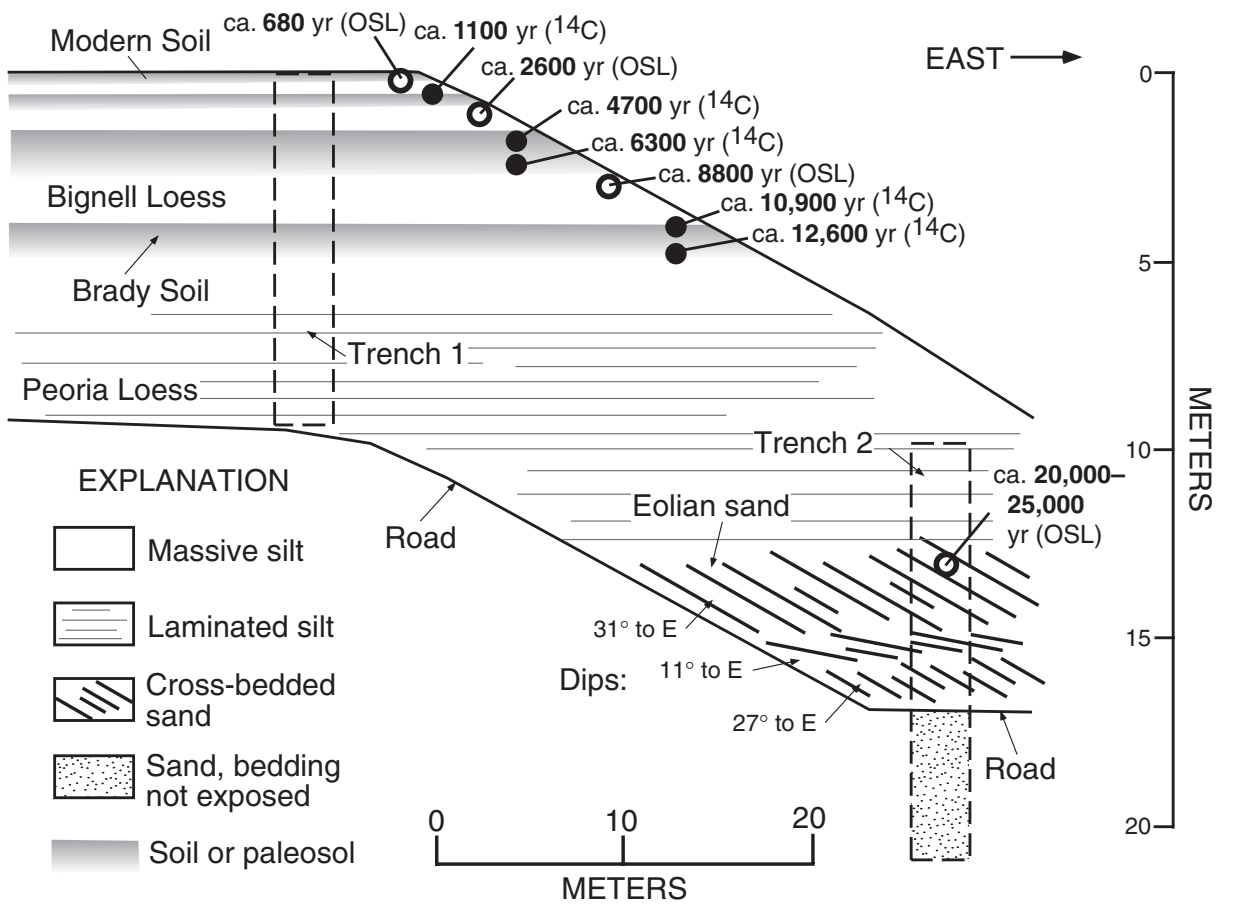

Figure 5. Stratigraphy, OSL and calibrated radiocarbon ages (yr B.P.), and sampling trenches at Moran Canyon, Nebraska. Radiocarbon ages are from this study (Table 1), OSL ages for Bignell Loess are from Mason et al. (2003a), and OSL age for eolian sand is from Bettis et al. (2003b). 


\section{Moran Canyon stratigraphy}

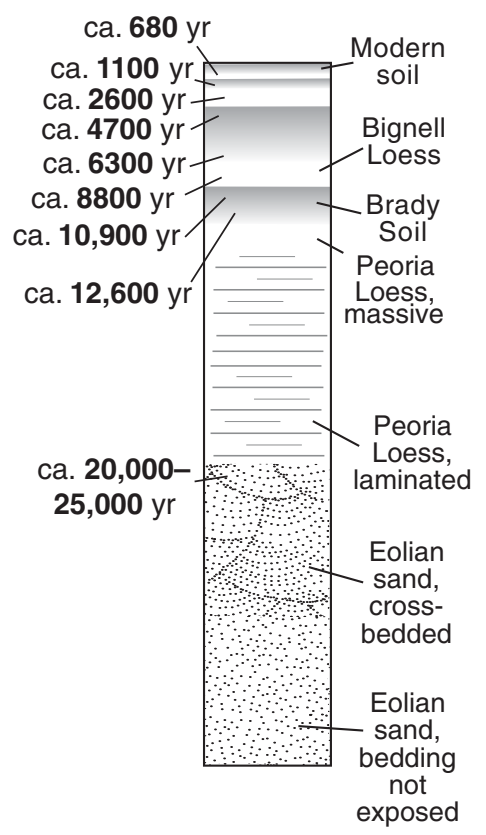

$\mathrm{Fe}_{2} \mathrm{O}_{3}(\%) \quad \mathrm{Mn}(\mathrm{ppm}) \quad \mathrm{K} / \mathrm{Rb}$

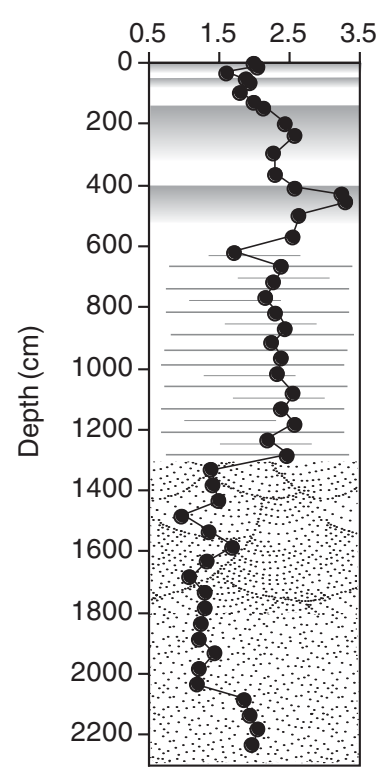

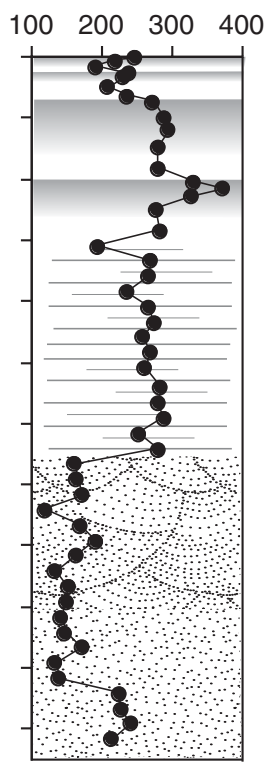
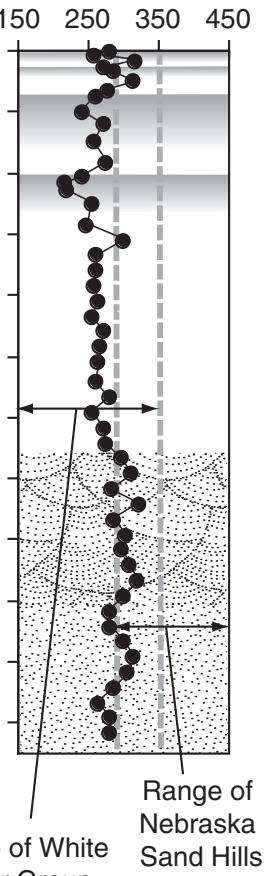

River Group

Figure 6. Stratigraphy, OSL and calibrated radiocarbon ages (yr B.P.) (sources as in Fig. 5), $\mathrm{Fe}_{2} \mathrm{O}_{3}$ and $\mathrm{Mn}$ contents (as proxies for fine-grained particles) and $\mathrm{K} / \mathrm{Rb}$ at Moran Canyon, Nebraska. Also shown is range of $\mathrm{K} / \mathrm{Rb}$ for loess sources; all geochemical data are from this study. Section shown is a composite of trench 1 and trench 2 samples as shown in Figure 5.

$40 \%$ sand contour line in Figure 12A. The silt content in Peoria Loess at Bignell Hill ranges from $37 \%$ to $66 \%$, although most depths have 50\%-60\% silt.

At Eustis the particle size throughout Peoria Loess is finer grained than at Bignell Hill. The sand content, with one exception, is lower than that at Bignell Hill and varies between $11 \%$ and $34 \%$, with most depths between $11 \%$ and $25 \%$ (Fig. 13B). This variation is consistent with the regional trend, where Eustis falls approximately on the 20\% sand content contour in Figure 12A. The silt content is higher than that at Bignell Hill, between $54 \%$ and $76 \%$ (one sample is $48 \%$ ). Particle size data presented here for Eustis are in broad agreement with those of Rousseau et al. (2007), although methods and particle size classes differ.

\section{MINERALOGY OF PEORIA LOESS IN NEBRASKA}

Bulk mineralogical analyses of upper Peoria Loess were determined from about three dozen localities across the east-west extent of Nebraska, on both sides of the Platte River, and at multiple depths in four sections (Bignell Hill,
Devils Den, Eustis, and Plattsmouth). Results indicate a composition similar to loess from other regions (Pye, 1987). Quartz and plagioclase are present in all samples, and most also contain mica, calcite, and dolomite. More than half the samples analyzed contain detectable $\mathrm{K}$-feldspar, and a few samples have detectable amounts of chlorite and amphibole. Peoria Loess in Nebraska can be compared with loess from other regions of North America (Illinois and Alaska), as well as potential source sediments, using ternary diagrams of XRD peak heights, which are measures of relative mineral abundance (not mass fractions). In this method, each mineral component is arrayed as a percentage of the sum of the three components in the diagram. The main difference between North American loesses we studied is carbonate mineral (calcite and dolomite) content, which is high in Peoria Loess from Illinois, has intermediate values in Nebraska, and is low in Alaska (Fig. 14).

Loess from Nebraska does not have a clear mineralogical overlap with any single source sediment when comparisons are made using ternary diagrams (Fig. 14). Many loess samples show overlap with sediments of the White River Group and Pierre Shale, but individually neither of these sources shows complete agreement with Peoria Loess. A lack of carbonates in sediments of the Nebraska Sand Hills results in a minimal overlap with the array of Peoria Loess samples from Nebraska. Although we have observed secondary carbonate streaks, nodules, and rhizoliths in some beds of the Pliocene sediments, we detected little or no calcite in the siltrich zones analyzed here (Fig. 14).

XRD analysis of oriented clays shows that Peoria Loess in both eastern and western Nebraska has a clay mineralogy dominated by smectite (Fig. 15). Smaller amounts of mica, kaolinite, and/or chlorite are also present. Quartz is present in the clay fraction, but there is no evidence of significant amounts of clay-sized feldspar. The clay mineral suite of Peoria Loess in Nebraska is similar to that of Peoria Loess in western Iowa.

Some of the mineralogical variability we observed in Peoria Loess in Nebraska is a function of carbonate mineral content. Calcite and dolomite can easily be identified by XRD analysis, and quantitative estimates can be made using $\mathrm{CaCO}_{3}$ content with a Chittick apparatus (calcite) and measurements of $\mathrm{CaO}$ and $\mathrm{MgO}$ content by XRF analysis (calcite and dolomite, plus 
other Ca-bearing minerals), as well as loss-onignition (LOI) at $900{ }^{\circ} \mathrm{C}$ (mostly $\mathrm{CO}_{2}$ loss from carbonate minerals, with lesser amounts from structural $\mathrm{H}_{2} \mathrm{O}$ and organic matter). Although $\mathrm{CaCO}_{3}$ content from a Chittick apparatus is a direct measure of calcite, it does not include dolomite in a $5 \mathrm{~min}$ reaction procedure. Furthermore, we found that this method has large uncertainties and poor reproducibility when carbonate contents are relatively low, as they are with Peoria Loess in Nebraska. $\mathrm{CaO}$ and $\mathrm{MgO}$ contents by XRF are accurate and precise and can reflect the presence of both calcite and dolomite. These elements also reflect the abundance of other $\mathrm{Ca}$ - and $\mathrm{Mg}$-bearing minerals, if present. Nevertheless, carbonates are the dominant Ca-bearing minerals at Eustis and Plattsmouth, where all carbonate proxies $\left(\mathrm{CaCO}_{3}, \mathrm{CaO}+\right.$ $\mathrm{MgO}+\mathrm{LOI}$, and calcite + dolomite/quartz peakheight ratio) parallel one another (Fig. 16).

A distinctive trend at Eustis is that all carbonate mineral proxies show general increases upsection. These carbonate trends parallel the upsection increase in mass accumulation rates (MAR) (Fig. 16). Our interpretation is that during periods of relatively low sedimentation rates, climatic conditions were humid enough that syndepositional leaching could take place. During periods of higher sedimentation rates, loess accumulation proceeded rapidly enough that syndepositional carbonate leaching was precluded.

\section{GEOCHEMISTRY OF PEORIA LOESS IN NEBRASKA}

\section{Major Element Geochemistry of Peoria Loess in Nebraska}

Major element geochemistry of sediments is conveniently portrayed using ternary diagrams. One approach eliminates elements $\left(\mathrm{Al}_{2} \mathrm{O}_{3}\right.$ and $\mathrm{Fe}_{2} \mathrm{O}_{3}$ ) dominated by clay minerals and emphasizes the relative abundance of quartz $\left(\mathrm{SiO}_{2}\right)$, feldspar plus mica $\left(\mathrm{Na}_{2} \mathrm{O}+\mathrm{K}_{2} \mathrm{O}\right)$, and the carbonate minerals, calcite-plus-dolomite $(\mathrm{CaO}+\mathrm{MgO})$. Another method is to eliminate the main proxy for quartz $\left(\mathrm{SiO}_{2}\right)$ and substitute elements that represent the relative abundance of clay minerals $\left(\mathrm{Al}_{2} \mathrm{O}_{3}\right.$ and $\left.\mathrm{Fe}_{2} \mathrm{O}_{3}\right)$. Trace elements that substitute for major elements in the feldspars and micas $(\mathrm{Ba}, \mathrm{Rb}, \mathrm{Sr})$ can also be used to characterize a sediment body, as well as trace elements that are enriched in the heavy mineral suite $(\mathrm{Zr}, \mathrm{Y}, \mathrm{Nb})$.

Because loess in Nebraska is found both north and south of the Platte River system, a question that has arisen is whether the two loess bodies are compositionally distinct (Winspear and Pye, 1995; Muhs et al., 1999). We analyzed two suites of Peoria Loess samples, on both
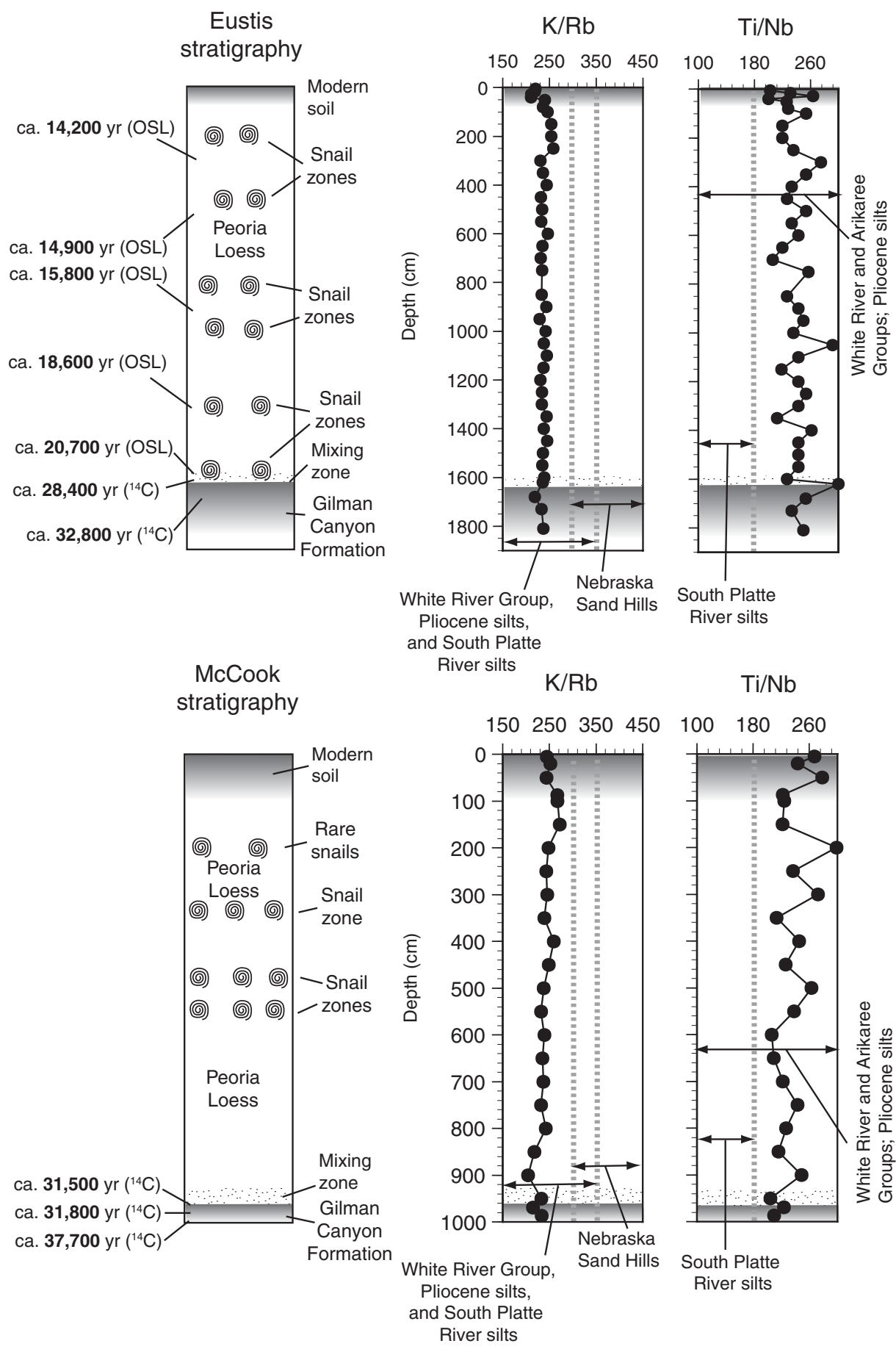

Figure 7. Stratigraphy, OSL and calibrated radiocarbon ages (yr B.P.), K/Rb, and Ti/Nb at Eustis (upper) and McCook (lower), Nebraska, and in various loess sources. OSL ages are from Roberts et al. (2003); all other data are from this study.

sides of the river system. Major element plots, both $\left(\mathrm{SiO}_{2}\right) / 10-(\mathrm{CaO}+\mathrm{MgO})-\left(\mathrm{Na}_{2} \mathrm{O}+\mathrm{K}_{2} \mathrm{O}\right)$ and $\left(\mathrm{Al}_{2} \mathrm{O}_{3}+\mathrm{Fe}_{2} \mathrm{O}_{3}\right) / 2-(\mathrm{CaO}+\mathrm{MgO})-\left(\mathrm{Na}_{2} \mathrm{O}+\right.$ $\mathrm{K}_{2} \mathrm{O}$ ), are in agreement with Winspear and Pye (1995) that loess bodies north and south of the Platte River system are compositionally similar
(Fig. 17). Trace element plots for $\mathrm{Ba} / 10-\mathrm{Rb}-\mathrm{Sr}$ (feldspars and micas) and $\mathrm{Zr} / 10-\mathrm{Y}-\mathrm{Nb}$ (heavy minerals) also show that the two loess bodies are not significantly different. Peoria Loess from eastern Colorado, taken from a newly sampled 5-m-thick section near Fort Morgan (Fig. 2) is 


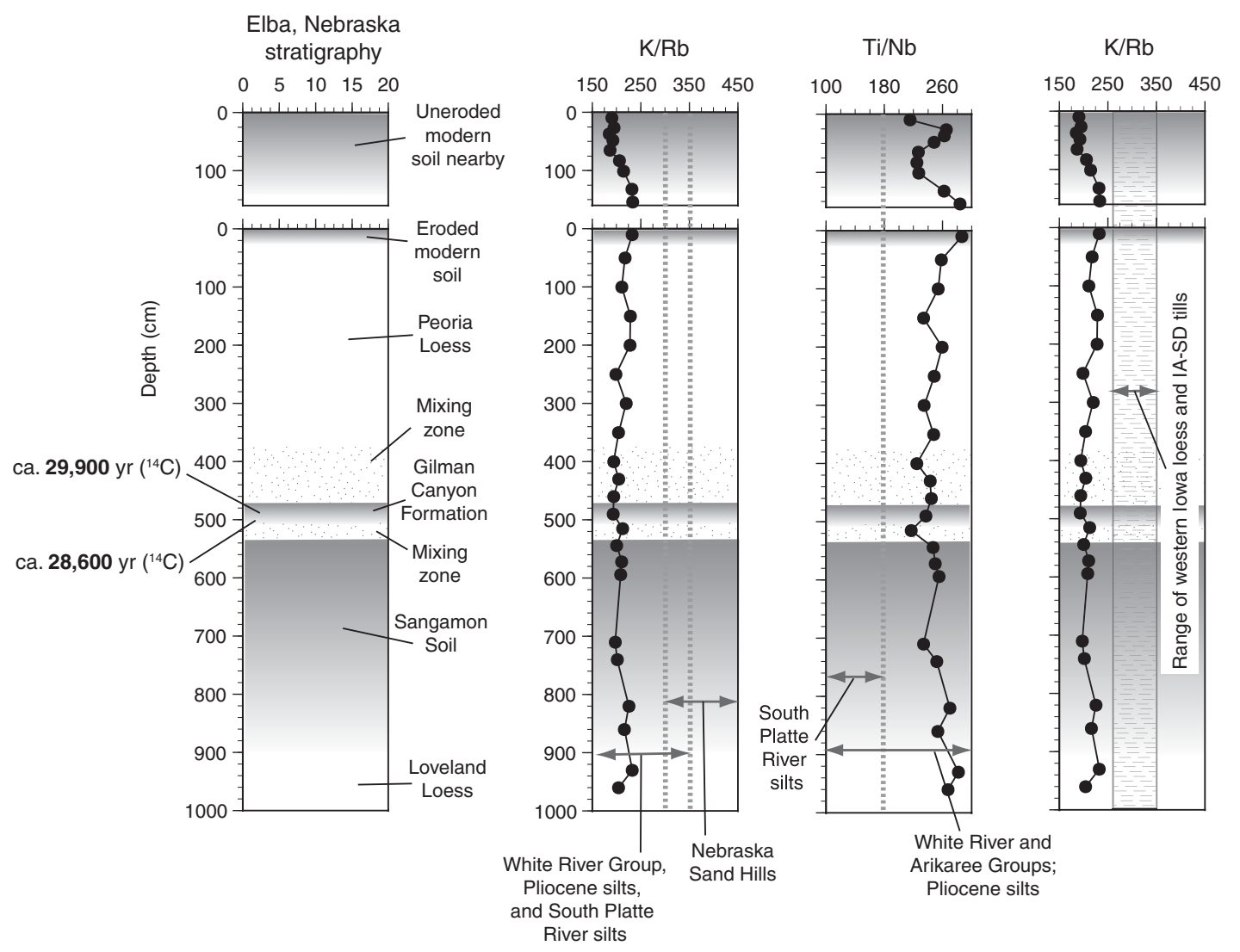

Figure 8. Stratigraphy and calibrated radiocarbon ages (yr B.P.), K/Rb, and Ti/Nb at Elba, Nebraska, and in various loess sources. IA-Iowa; SD—South Dakota.
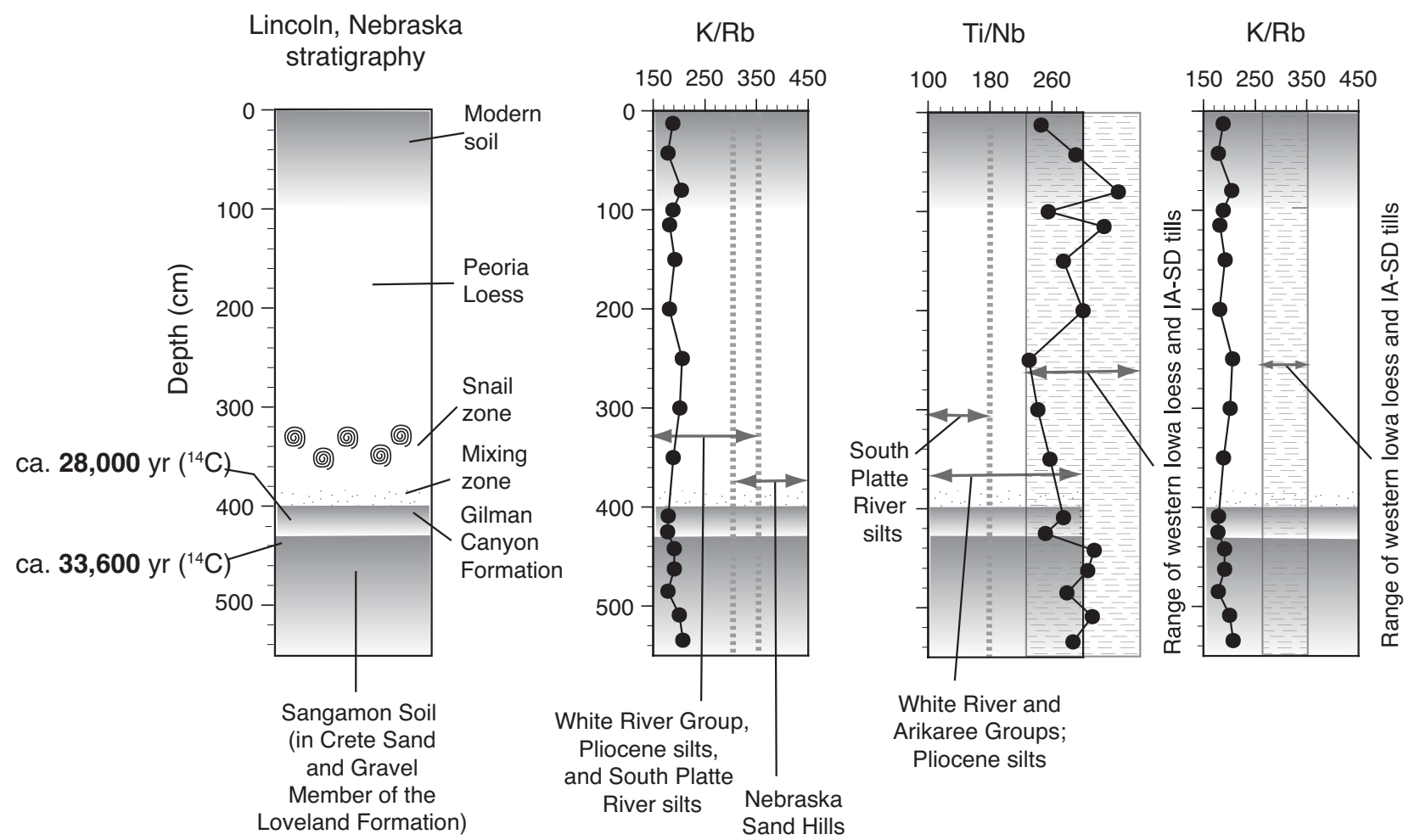

Figure 9. Stratigraphy and calibrated radiocarbon ages (yr B.P.), K/Rb, and Ti/Nb at Lincoln, Nebraska, and in various loess sources. Stratigraphy and radiocarbon ages are from Mandel and Bettis (1995); geochemical data are from this study. IAIowa; SD—South Dakota. 

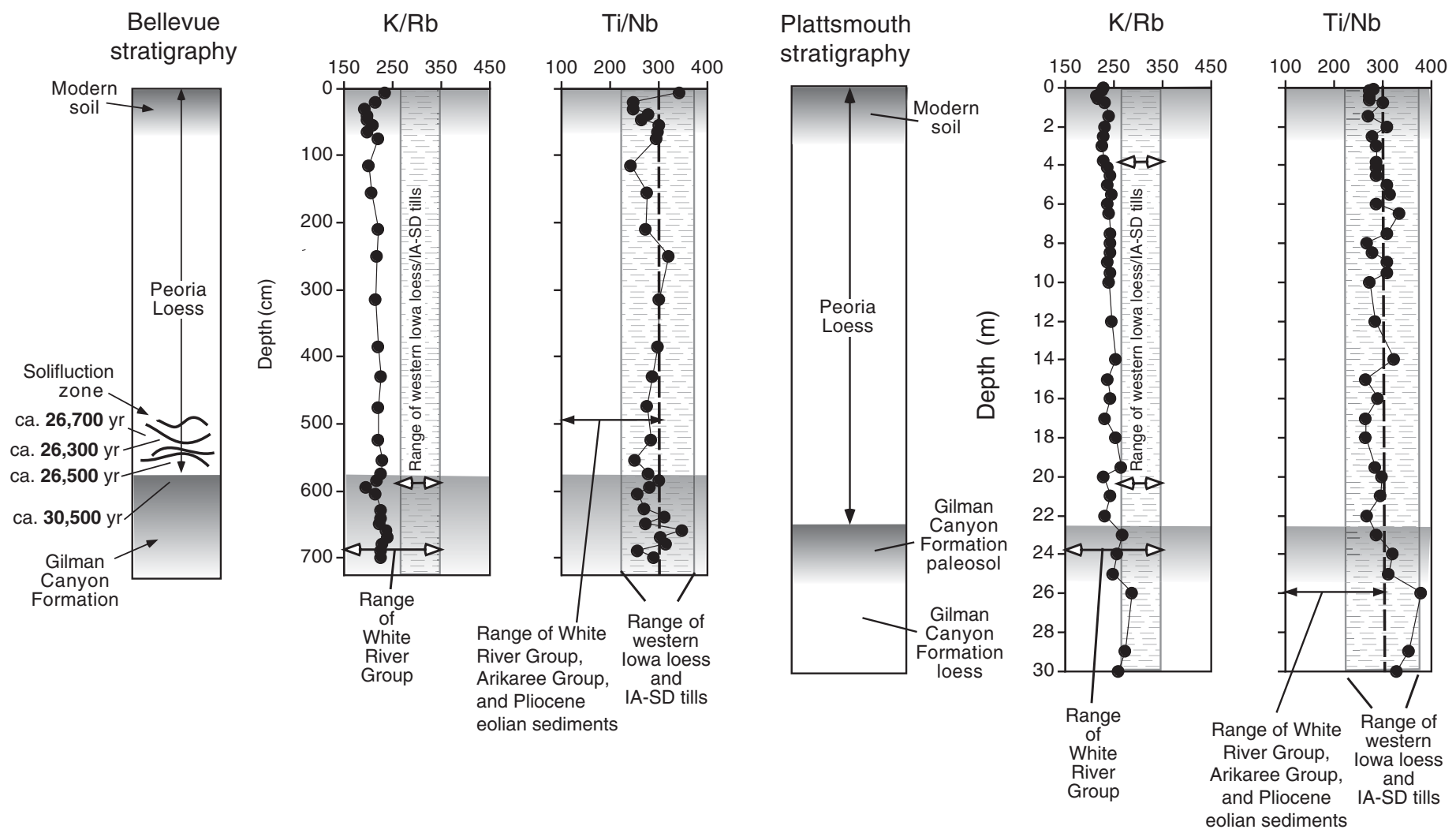

Figure 10. Stratigraphy and calibrated radiocarbon ages (yr B.P.), K/Rb, and Ti/Nb at Bellevue and Plattsmouth, Nebraska, and various loess sources. Radiocarbon ages are from Mandel and Bettis (1995) and this study (Table 1).

not significantly different from either loess body in Nebraska (Fig. 17).

Ternary diagrams of major elements can be used to evaluate potential source sediments for Peoria Loess in Nebraska. A plot of $\left(\mathrm{SiO}_{2}\right) / 10$ $\left(\mathrm{Al}_{2} \mathrm{O}_{3}+\mathrm{Fe}_{2} \mathrm{O}_{3}\right) / 2-\left(\mathrm{Na}_{2} \mathrm{O}+\mathrm{K}_{2} \mathrm{O}\right)$ shows that Peoria Loess is closest to the White River Group (Fig. 18C). However, this interpretation must be used with caution, because clay-related elements $\left(\mathrm{Al}_{2} \mathrm{O}_{3}\right.$ and $\left.\mathrm{Fe}_{2} \mathrm{O}_{3}\right)$ are much lower in the dune sediments and much higher in Pierre Shale. However, a $\left(\mathrm{SiO}_{2}\right) / 10-(\mathrm{CaO}+\mathrm{MgO})$ $\left(\mathrm{Na}_{2} \mathrm{O}+\mathrm{K}_{2} \mathrm{O}\right)$ diagram includes elements that do not have such a distinctive bias toward particle size. Using this plot (Fig. 18A), Peoria Loess in Nebraska overlaps Pierre Shale and White River Group sediments but is distinct from the Nebraska Sand Hills or dunes in Colorado, which lack significant amounts of carbonate minerals. The $\left(\mathrm{SiO}_{2}\right) / 10-(\mathrm{CaO}+\mathrm{MgO})-\left(\mathrm{Na}_{2} \mathrm{O}+\mathrm{K}_{2} \mathrm{O}\right)$ diagram suggests that Peoria Loess could have been derived from a mixture of White River Group and Pierre Shale sediments.

Using the same major element ternary diagrams, differences between the compositions of loesses from widely separated regions can be recognized easily. Loess from New Zealand has a low carbonate $(\mathrm{CaO}+\mathrm{MgO})$ content and a high feldspar $\left(\mathrm{Na}_{2} \mathrm{O}+\mathrm{K}_{2} \mathrm{O}\right)$ content, probably from volcanic sources (Fig. 18B). In contrast, loess from Illinois has a relatively high carbonate content (reflecting calcite-rich and dolomite-rich outwash sources) and a relatively low feldspar content. Peoria Loess in Nebraska falls closest to the composition of Alaskan loess. A plot of $\left(\mathrm{SiO}_{2}\right) / 10-\left(\mathrm{Al}_{2} \mathrm{O}_{3}+\mathrm{Fe}_{2} \mathrm{O}_{3}\right) / 2-\left(\mathrm{Na}_{2} \mathrm{O}+\right.$ $\mathrm{K}_{2} \mathrm{O}$ ), which omits the carbonate mineral proxy $(\mathrm{CaO}+\mathrm{MgO})$, also shows loess differences from region to region. In this array, Peoria Loess in Nebraska has little overlap with loesses from other areas (Fig. 18D).

\section{Use of $\mathrm{K} / \mathrm{Rb}$ and $\mathrm{Ti} / \mathrm{Nb}$ as Provenance Indicators}

Ratios of geochemically similar major and trace elements in minerals can be useful in sediment provenance studies. For example, Rb substitutes for $\mathrm{K}$ in minerals such as $\mathrm{K}$-feldspars and micas. Owing to lattice constraints and ionic radii, $\mathrm{Rb}$ is incorporated more easily in micas (muscovite, biotite, illite) than in K-feldspars (Heier and Adams, 1964; Lange et al., 1966). Thus, $\mathrm{K} / \mathrm{Rb}$ is lower in micas than in K-feldspars. Two other elements we examined as provenance indicators are $\mathrm{Ti}$ and $\mathrm{Nb}$. Although $\mathrm{Ti}$ is found in low concentrations in a few primary minerals (e.g., biotite, hornblende, zircon), it is a major constituent in sphene, ilmenite, and rutile (Parker and Fleischer, 1968). Niobium commonly substitutes for $\mathrm{Ti}$ and thus $\mathrm{Ti} / \mathrm{Nb}$ ratios will vary primarily with the mineralogy and source rocks of Ti-bearing heavy minerals.

In using geochemistry for sediment provenance studies, there is a possibility of mineral size-partitioning bias, with the result that particular elements are concentrated in certain size fractions (Shilts, 1993). In our study, however, neither $\mathrm{K}$ or $\mathrm{Rb}$ concentrations nor element ratios are correlated with any size fraction, so we conclude there is little or no particle size bias. Ti shows a modest $\left(r^{2}=0.37\right)$ positive linear correlation with clay content, but not with other particle size classes. Nb shows no correlation with any particle size class.

$\mathrm{K} / \mathrm{Rb}$ and $\mathrm{Ti} / \mathrm{Nb}$ have not been used extensively in provenance studies for eolian sediments. Therefore, we explore here whether these element ratios can distinguish loesses derived from different sources. We selected loess samples of approximately the same age from China and different regions of North America, including Alaska, Colorado, Kansas, and northwestern Iowa. 
A Across Nebraska:

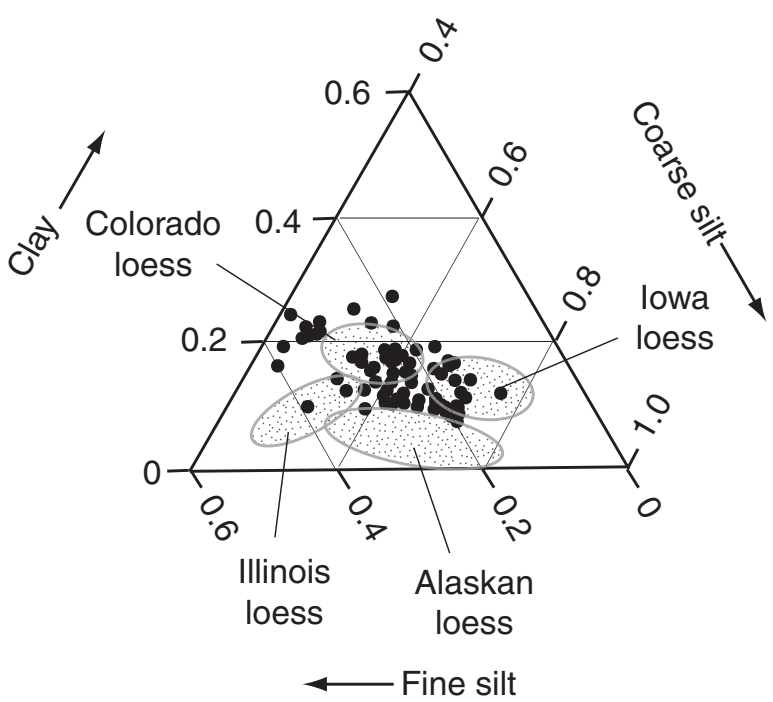

C Eustis, Nebraska:

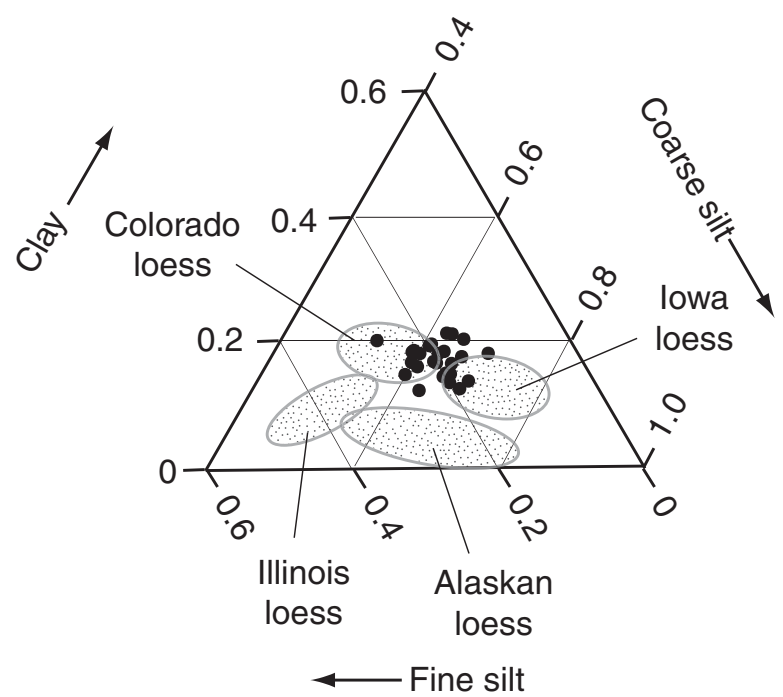

B Bignell Hill, Nebraska:

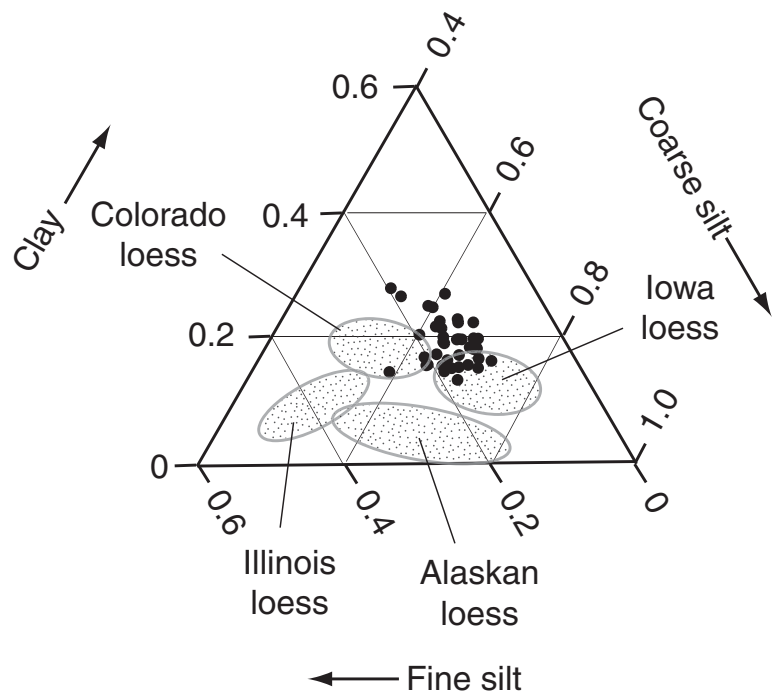

D Plattsmouth, Nebraska:

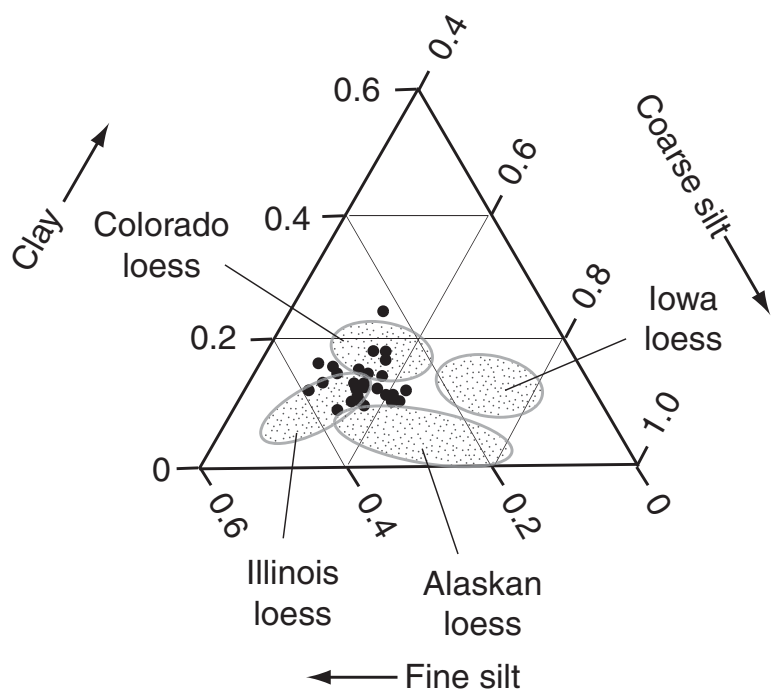

Figure 11. Abundance of coarse silt (53-20 $\mu \mathrm{m})$, fine silt $(20-2 \mu \mathrm{m})$, and clay $(<2 \mu \mathrm{m})$, on a sand-free basis, of Peoria Loess from (A) shallow samples across the state, (B) Bignell Hill, (C) Eustis, and (D) Plattsmouth (all localities are shown in Fig. 2). Also shown are ranges of these particle sizes from Peoria Loess (or its equivalent) from Fairbanks, Alaska (Gold Hill, Halfway House, and Birch Hill localities; Muhs et al., 2003a), Sioux City, Iowa (this study), Greenbay Hollow, Illinois (Grimley et al., 1998; Muhs et al., 2001; Muhs and Bettis, 2003), and Fort Morgan, Colorado (this study). 
Muhs et al.
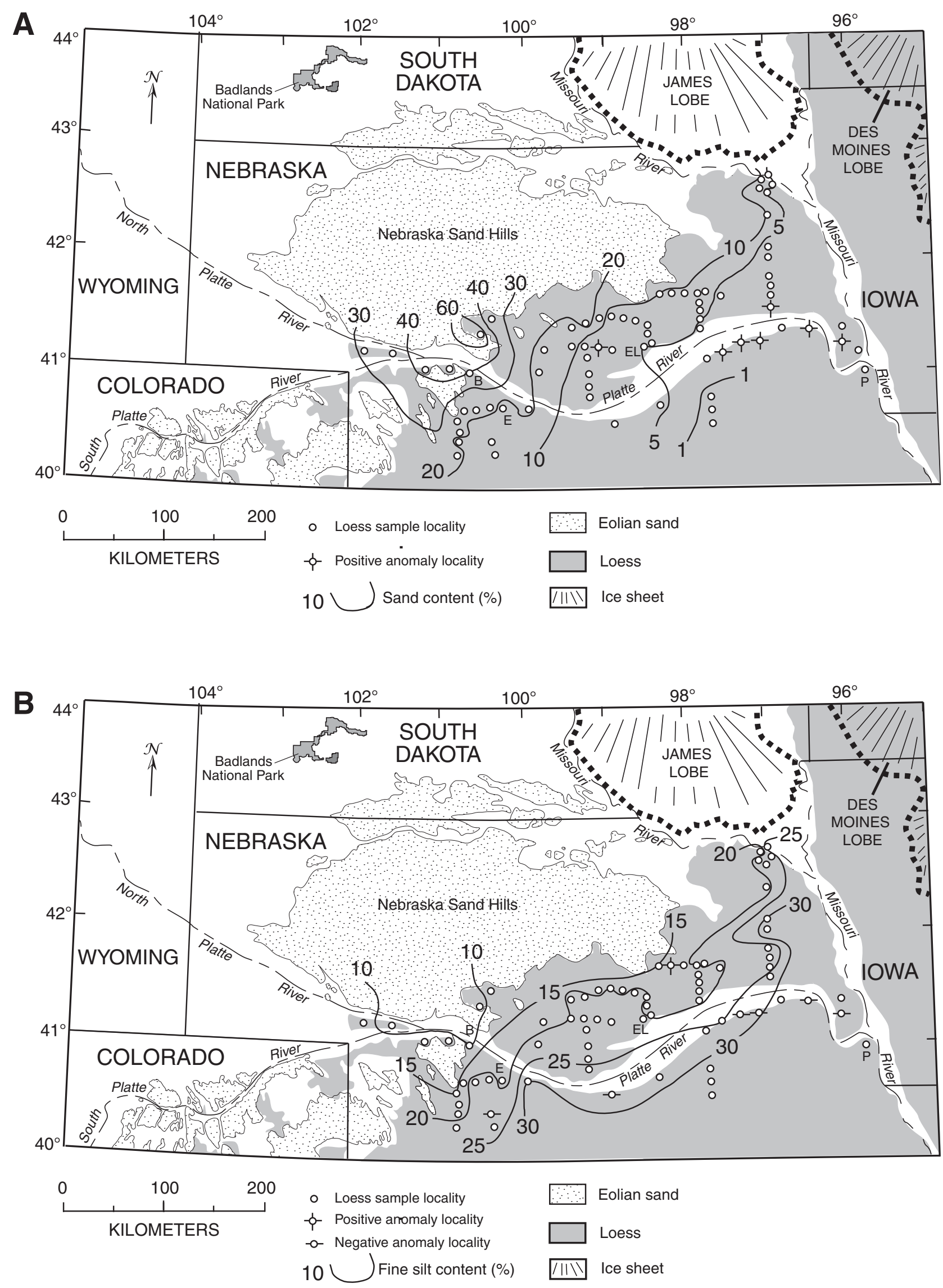


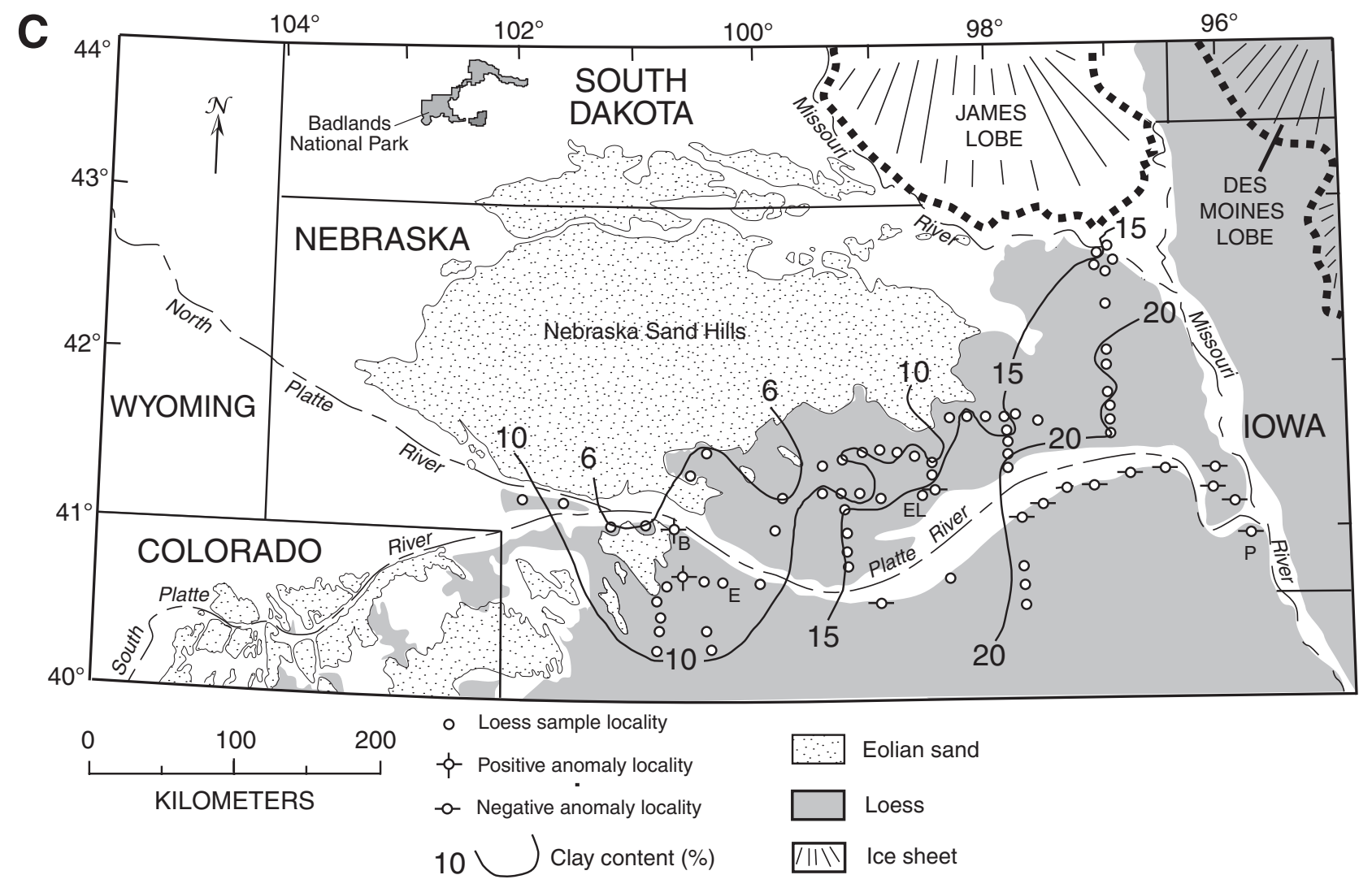

Figure 12 (on this and previous page). (A) Sand (>53 $\mu \mathrm{m}$ ) content of Peoria Loess in Nebraska (open circles). (B) Fine silt (20-2 $\mu \mathrm{m})$ content of Peoria Loess in Nebraska (open circles). (C) Clay $(<2 \mu \mathrm{m})$ content of Peoria Loess in Nebraska (open circles). Note that loess in the northeastern part of the map area is beneath till of the Des Moines lobe. B-Bignell Hill; E-Eustis; EL-Elba; P-Plattsmouth.

Because Peoria Loess from northwestern Iowa is compared in detail with Peoria Loess from Nebraska, a brief description of a new loess section studied is provided here. We sampled a 30-m-thick exposure of Peoria Loess at a locality called Sergeant Bluff, near Sioux City, Woodbury County, Iowa (Fig. 19). Peoria Loess in this section is unleached, and the lower $\sim 15$ $m$ of the section shows laminations. The locality is situated where the Missouri River was almost certainly the primary source of sediment. This interpretation is supported by the high contents $(60 \%-73 \%)$ of coarse silt in the loess (Fig. 19), suggesting a short distance of transport. The James Lobe and Des Moines Lobe (Figs. 1 and 2) of the Laurentide ice sheet provided silt-rich outwash to the Missouri River. Tills from these two glacial lobes are derived from Cretaceous shale and limestone, Paleozoic limestone and dolomite, and Precambrian crystalline rocks traversed by the Laurentide ice sheet in the northern United States and Canada (Hallberg and Kemmis, 1986). We sampled basal tills of the James Lobe in South Dakota and the Des Moines Lobe in Iowa and separated the $<125$ $\mu \mathrm{m}$ fraction for geochemical analyses. Both $\mathrm{K} /$ $\mathrm{Rb}$ and $\mathrm{Ti} / \mathrm{Nb}$ indicate that the Peoria Loess at Sioux City is derived ultimately from Laurentide ice sheet tills via deflation from the Missouri River Valley (Fig. 19).

Results of the regional loess comparison show that $\mathrm{K} / \mathrm{Rb}$ and $\mathrm{Ti} / \mathrm{Nb}$ can distinguish loesses from diverse source areas (Figs. 20A and 20B). Loess from eastern Colorado and northern Kansas show compositional similarities. However, loess from Colorado and Kansas is distinguished from Chinese loess by lower Ti/Nb. The three Alaskan loess groups have higher $\mathrm{Ti} / \mathrm{Nb}$ than loess from Colorado, Kansas, and Iowa. In addition, the Alaskan loesses have $\mathrm{K} / \mathrm{Rb}$ that differ from one another. We conclude from this simple test that $\mathrm{K} / \mathrm{Rb}$ and $\mathrm{Ti} / \mathrm{Nb}$, though not perfect, are useful provenance indicators for loess.

There are distinct differences in $\mathrm{K} / \mathrm{Rb}$ between some of the potential sources of Peoria Loess in Nebraska (Figs. 20C-20F). High K/Rb values in the Nebraska Sand Hills and Colorado dunes likely represent the dominance of K-feldspar over mica in the K-mineral suites of these sediments. Distinct $\mathrm{K} / \mathrm{Rb}$ values are also found for the two fluvial sediment groups, South Platte River sediments and Missouri River sediments (as proxied by western Iowa loess at Sioux City). Pierre Shale has relatively low $\mathrm{K} / \mathrm{Rb}$, distinct from Pliocene eolian sediments, which probably reflects a higher mica content in the shale. However, Pliocene eolian sediments, Arikaree Group sediments, and White River Group sediments all have similar K/Rb.

The various source sediments have fewer differences in $\mathrm{Ti} / \mathrm{Nb}$ values (Figs. $20 \mathrm{C}-20 \mathrm{~F}$ ). The White River Group, Arikaree Group, Pierre Shale, Pliocene eolian sediments, and Colorado dune sands all have overlapping Ti/Nb. However, South Platte River sediments have generally lower Ti/Nb, mostly between 100 and 200 . Missouri River sediments (proxied by Iowa loess) have more variable but generally higher $\mathrm{Ti} / \mathrm{Nb}$. Because $\mathrm{Nb}$ concentrations are near the detection limit of the ED-XRF method in the Nebraska Sand Hills sediments, we do not calculate $\mathrm{Ti} / \mathrm{Nb}$ for these eolian sands.

Most samples of Peoria Loess in Nebraska have $\mathrm{K} / \mathrm{Rb}$ between 200 and 250 , and $\mathrm{Ti} / \mathrm{Nb}$ between 200 and 300 (Fig. 20). A comparison 


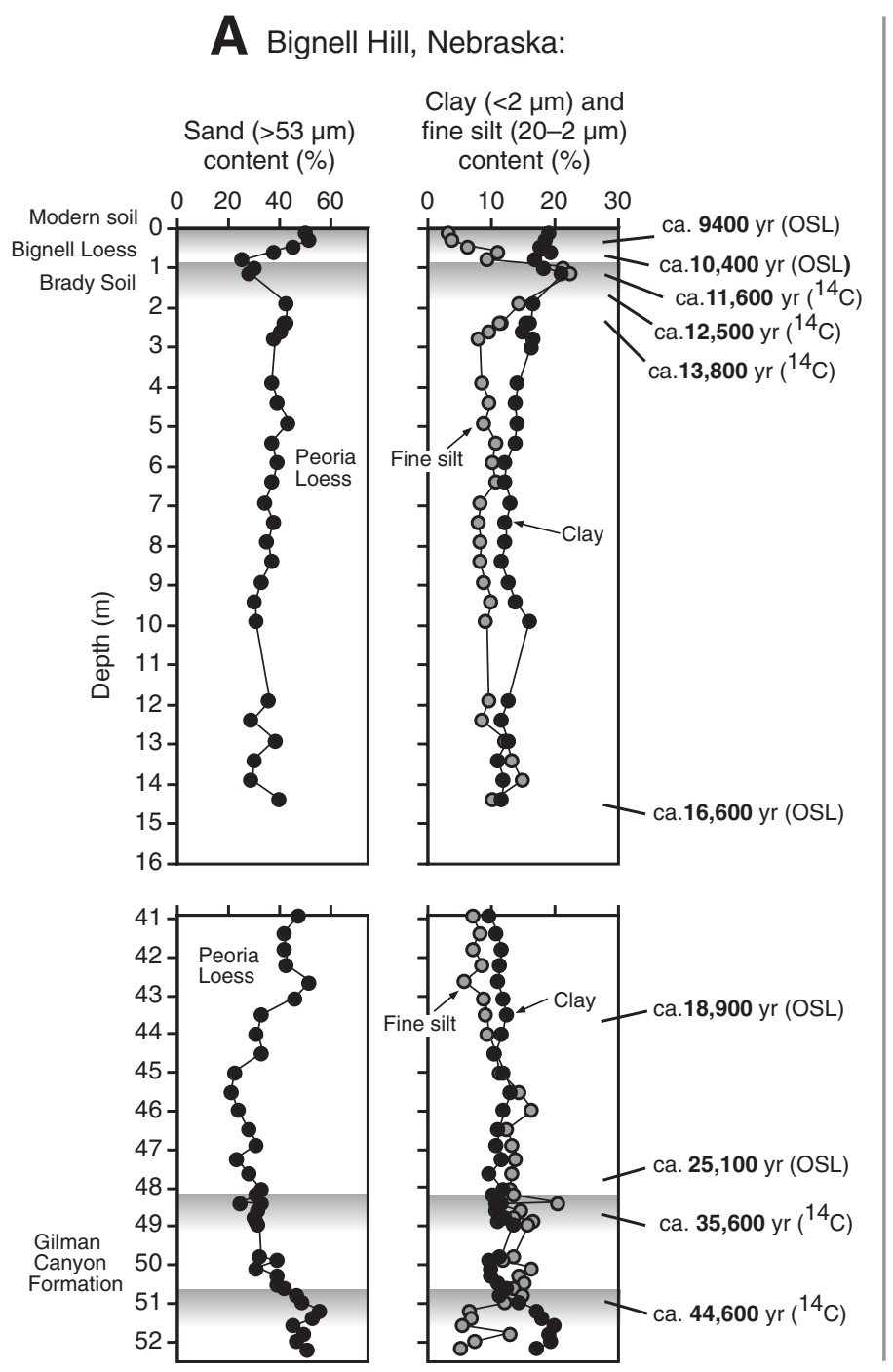

B Eustis, Nebraska:

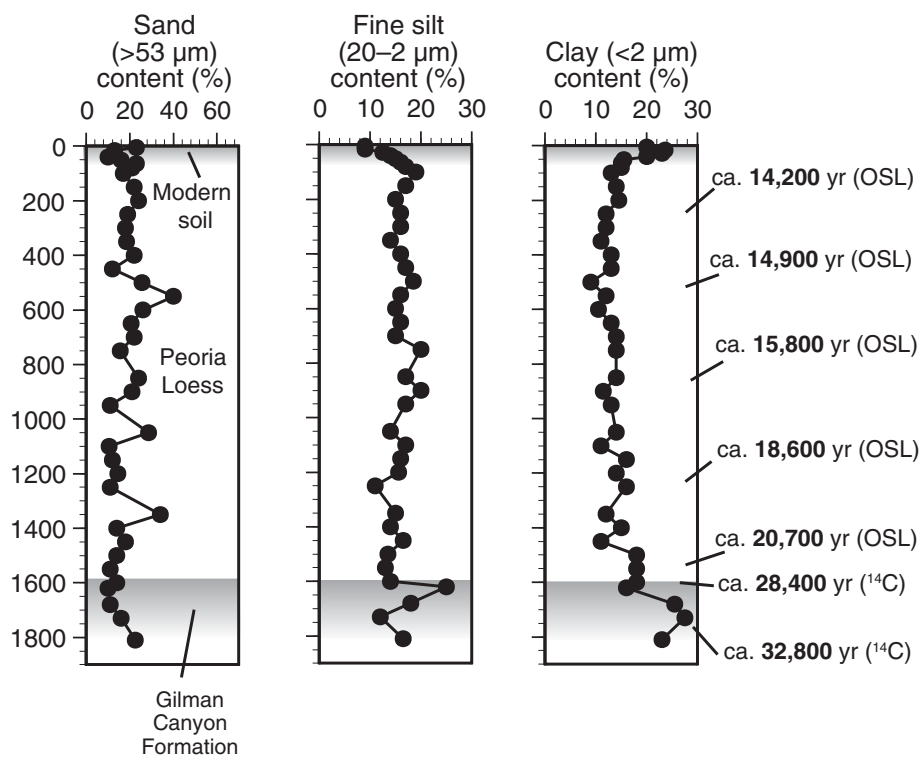

Figure 13. Stratigraphy, OSL and calibrated radiocarbon ages (yr B.P.), and sand, fine silt, and clay content at Bignell Hill (A) and Eustis (B), Nebraska. of $\mathrm{K} / \mathrm{Rb}$ values suggests that the Nebraska Sand Hills are not a likely sole source for Peoria Loess (Fig. 20). Although Peoria Loess has some overlap with the South Platte River sediments, there is almost no overlap with Missouri River-derived silts (Iowa loess), which have K/ $\mathrm{Rb}$ ratios between 265 and 311. Some Pierre Shale samples have $\mathrm{Ti} / \mathrm{Nb}$ similar to Peoria Loess in Nebraska but also have $\mathrm{K} / \mathrm{Rb}$ that are too low. However, Peoria Loess overlaps the fields defined by $\mathrm{K} / \mathrm{Rb}$ and $\mathrm{Ti} / \mathrm{Nb}$ for the White River Group, Arikaree Group, and Pliocene eolian sediments. A simple interpretation is that these latter three sediments are the most likely candidates for the dominant sources of Peoria Loess in Nebraska. However, it is also possible that mixtures of geochemically distinct source sediments can explain the compositional variation of the loess, a possibility we discuss below.

$\mathrm{K} / \mathrm{Rb}$ and $\mathrm{Ti} / \mathrm{Nb}$ in sections across an east-west distance of $\sim 350 \mathrm{~km}$ in Nebraska suggest that compositions of Peoria Loess have changed very little, if at all, over the last glacial period (Figs. 3, 4, and 6-10). At Bignell Hill and Devils Den, K/ $\mathrm{Rb}$ at most depths is $\sim 250$ or slightly lower, which falls within the range of the White River Group, Arikaree Group, Pliocene beds, and sediments of the South Platte River, but outside that of the Nebraska Sand Hills (Figs. 3, 4). Exceptions to this are sandy zones, prominent at $\sim 42 \mathrm{~m}$ depth at Bignell Hill and $\sim 30 \mathrm{~m}$ and $\sim 37 \mathrm{~m}$ depths at Devils Den, where $\mathrm{K} / \mathrm{Rb}$ values are higher. The same is true for eolian sand that underlies Peoria Loess at Moran Canyon, at depths below 1300 $\mathrm{cm}$ (Fig. 6). Ti/Nb in Peoria Loess at Bignell Hill is higher than that of sediments of the South Platte River but within the ranges of the White River Group, Arikaree Group, and Pliocene eolian sediments. At Eustis and McCook, K/Rb is almost monotonic with depth and is similar to that at Bignell Hill (Fig. 7). All K/Rb values at Eustis and McCook fall within the middle of the range of values for the White River Group, Arikaree Group, Pliocene eolian sediments, and South Platte River sediments. Ti/Nb values at Eustis and McCook are more variable with depth than $\mathrm{K} / \mathrm{Rb}$, but all values fall within the range of the White River Group, Arikaree Group, and Pliocene eolian sediments.

The sections at Elba and Lincoln allow us to evaluate the composition of Peoria Loess over time in the central and eastern parts of Nebraska (Figs. 8, 9). These sections were originally described by May et al. (1995) and Mandel and Bettis (1995). Both sections have thinner Peoria Loess than the localities farther west. In fact, the modern soil in the main section at Elba is clearly eroded when compared with a more stable locality a few hundred meters away (Fig. 8). At both sections, $\mathrm{K} / \mathrm{Rb}$ values in Peoria Loess do not differ significantly from the range of values found in the stratigraphic sections farther west. Furthermore, $\mathrm{K} / \mathrm{Rb}$ values in both sections are 

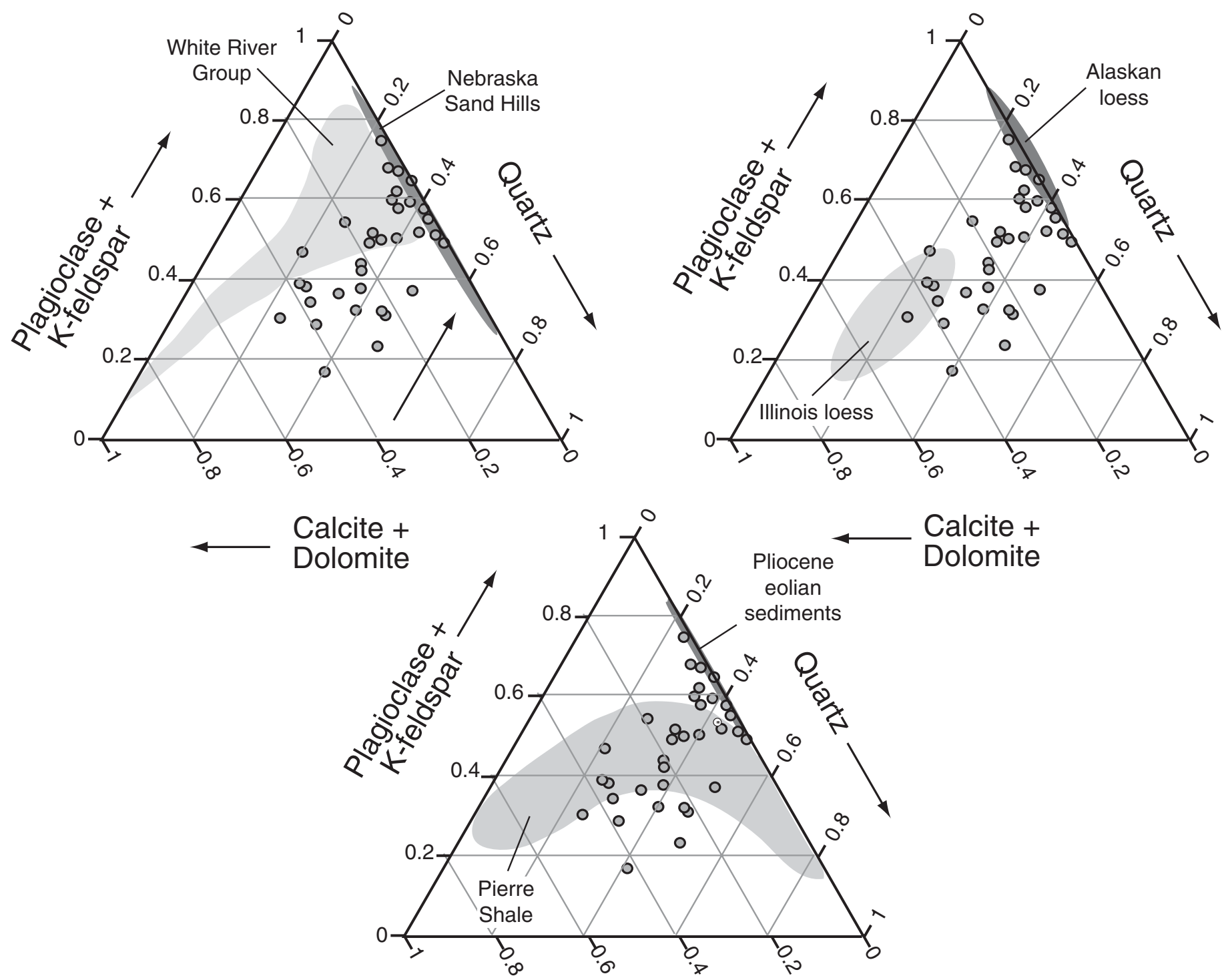

Calcite +

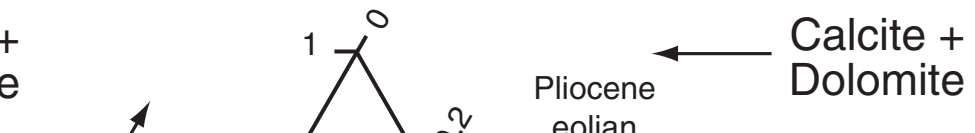




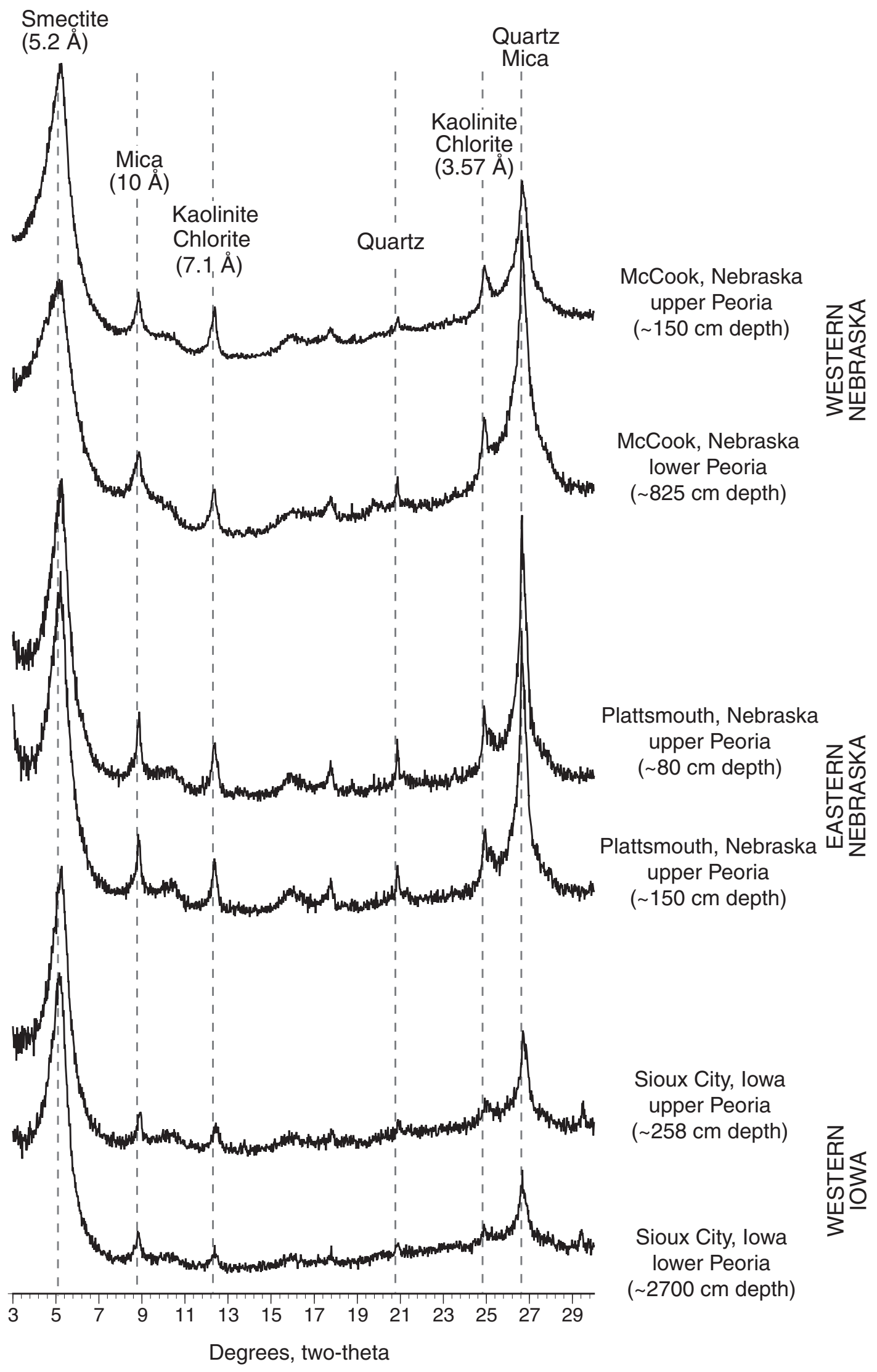

Figure 15. X-ray diffractograms for Mg-saturated, glycolated clay mineral separates of Peoria Loess from eastern Nebraska, western Nebraska, and western Iowa, and identification of clay mineral species. 

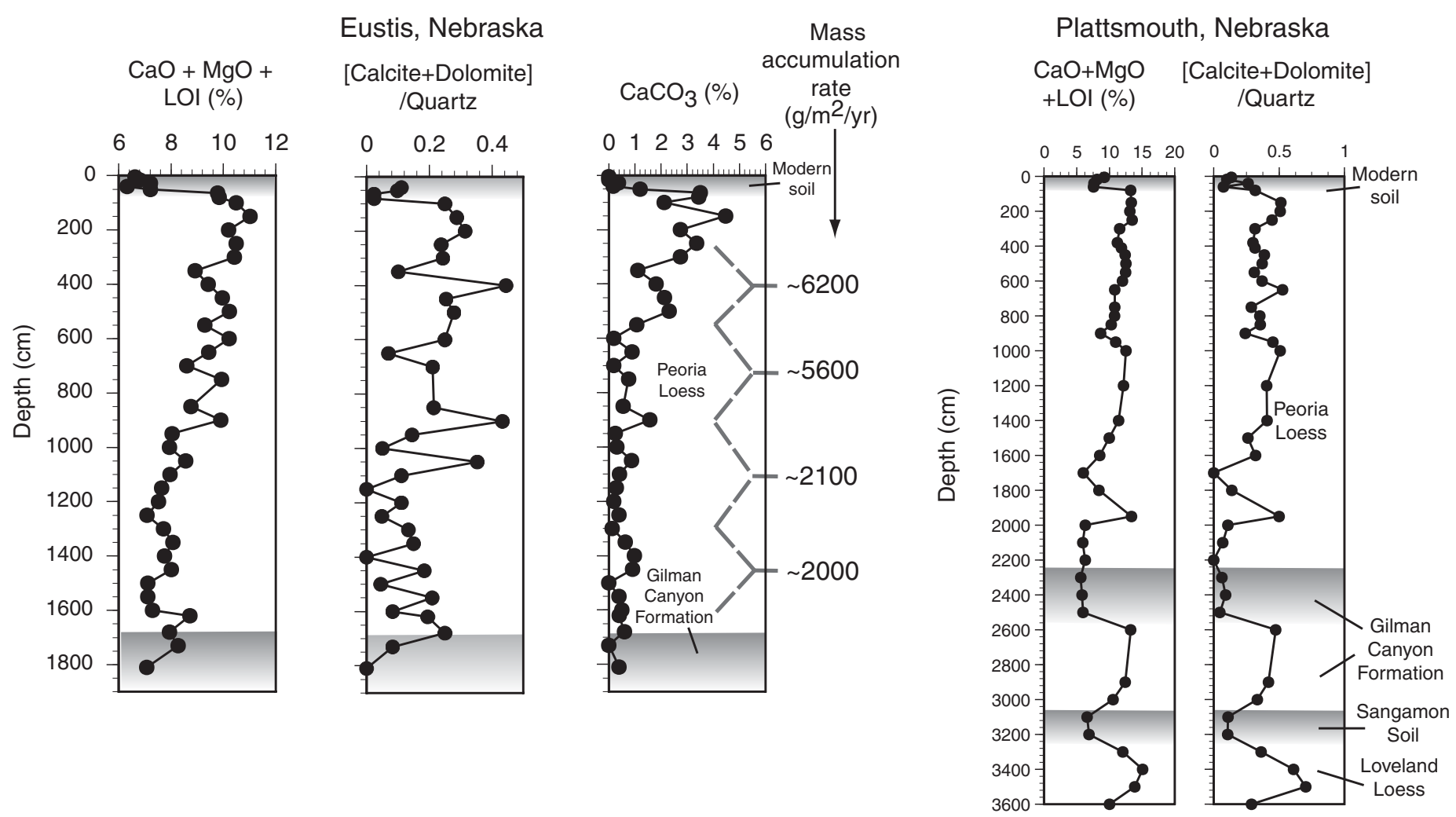

Figure 16. $\mathrm{CaO}+\mathrm{MgO}+\mathrm{LOI}$ compared with calcite + dolomite/quartz at Eustis and Plattsmouth, Nebraska. Also shown for Eustis are $\mathrm{CaCO}_{3}$ values (this study) and mass accumulation rates (MAR), from Roberts et al. (2003). LOI-loss on ignition.

would require alternations of northwesterly winds to provide dune sand from the Nebraska Sand Hills and southeasterly winds to provide river sediment from the Platte River Valley. The particle size data presented earlier argue against such a sequence of events.

\section{Peoria Loess Localities near the Missouri River in Nebraska}

An important question for loess origins and paleowinds is whether the Missouri River Valley served as a significant source of loess in Nebraska, because this river drained the Laurentide ice sheet. The Missouri River Valley borders northeastern and eastern Nebraska (Fig. 2). Mason (2001) and Mason et al. (2007) point out that in northeastern and east-central Nebraska, there is a narrow $(<25 \mathrm{~km})$ zone of westward-thinning loess, also apparent in the data of Swinehart et al. (1994a). Mason (2001) suggests that these trends could be the result of loess derivation from the Missouri River floodplain, perhaps from infrequently occurring easterly winds, an idea also proposed by Flint (1971) and Handy (1976).

In order to test the hypothesis of Missouri River contributions to loess in eastern Nebraska, we examined two sections near Bellevue and Plattsmouth, both $\sim 1 \mathrm{~km}$ west of the Missouri River (Fig. 2). K/Rb values in Peoria Loess at both Bellevue and Plattsmouth fall mostly within the range of values for the White River Group and outside the range of values for western Iowa loess and Laurentide ice sheet tills of South Dakota and Iowa (Fig. 10). White River Group sediments and western Iowa loess and Laurentide tills show considerable overlap in their ranges of $\mathrm{Ti} / \mathrm{Nb}$. Thus, $\mathrm{Ti} / \mathrm{Nb}$ is less useful as a provenance indicator in comparing these two source sediments. Unfortunately, loess composition at both Bellevue and Plattsmouth falls mostly within the area of overlap of Ti/ $\mathrm{Nb}$ for White River Group sediments and western Iowa loess, so our interpretations are not definitive. Nevertheless, Ti/Nb values at both Bellevue and Plattsmouth are higher ( 300) than is typical for loess in central and western Nebraska. This observation permits an interpretation that some part of the heavy mineral fraction could have been derived from a local Missouri River source.

The amount of influence of the Missouri River on Peoria Loess in Nebraska can also be examined with a north-south transect (Fig. 2). In this transect, $\mathrm{K} / \mathrm{Rb}$ decreases southward systematically, away from the Missouri River (Fig. 21). In addition, the northernmost localities in this transect have $\mathrm{K} / \mathrm{Rb}$ values that fall within the range of northwestern Iowa loess, whereas those greater than $30 \mathrm{~km}$ south of the Missouri River do not. Ti/Nb values, although less definitive, are consistent with this trend. Carbonate mineral abundances (relative to stable quartz), plus geochemical proxies for calcite and dolomite $(\mathrm{CaO}+\mathrm{MgO}+\mathrm{LOI})$, decrease with distance south of the river. In particular, localities within $\sim 30 \mathrm{~km}$ of the Missouri River show carbonate values within the range of western Iowa loess, and higher values than those in the Peoria Loess of central and western Nebraska (Fig. 21). These trends permit an interpretation of Missouri River influence on loess composition within $\sim 30 \mathrm{~km}$ of the river, at least for some minerals such as micas, feldspars, and carbonates. This interpretation is consistent with thickness observations made by Mason (2001) and Mason et al. (2007) and isotopic compositions reported by Aleinikoff et al. (2008). However, because of where our transect is located (Fig. 2), our only possible paleowind interpretation is that loesstransporting winds had a northerly component (northwest, north, or northeast). 

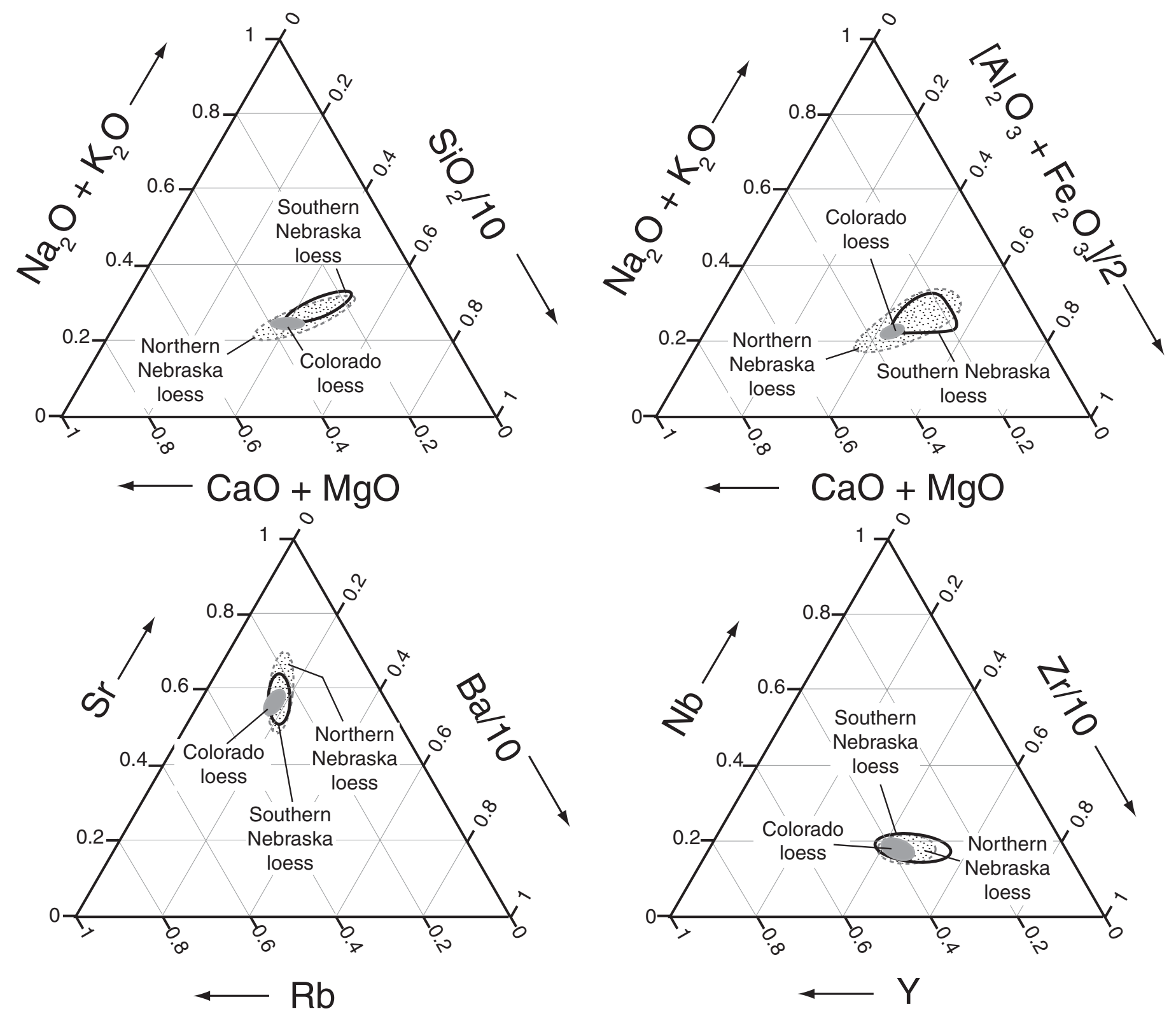

Figure 17. Ternary diagrams showing ranges of major and trace element values for Peoria Loess in Nebraska north of the Platte River system (northern Nebraska loess, $n=52$ ) compared with ranges of loess south of the Platte River system (southern Nebraska loess, $n=23$ ). Also shown are similar data for Peoria Loess in Colorado, from Fort Morgan (Fig. 2). All data generated by wavelength-dispersive X-ray fluorescence from the present study.

\section{DISCUSSION}

\section{Chronology of Peoria Loess Deposition in Nebraska}

The radiocarbon ages presented here, along with radiocarbon and OSL ages reported earlier by Mandel and Bettis (1995), Muhs et al. (1999), Johnson and Willey (2000), Roberts et al. (2003), and Mason et al. (2003a), allow us to infer the timing of Peoria Loess deposition in Nebraska. At widely separated localities in
Nebraska, earliest Peoria Loess deposition began ca. $26,000-25,000$ cal yr B.P. It is possible that the start of Peoria Loess deposition occurred later at some localities (Eustis and Devils Den). An alternative explanation is that these sections underwent some erosion of earliest Peoria Loess in their lower parts before later Peoria Loess deposition. In any case, OSL ages indicate that at Bignell Hill, Eustis, and Devils Den, Peoria Loess deposition rates were at a maximum from ca. 18,000 to ca. 14,000 cal yr B.P. (Roberts et al., 2003), accompanied by upsection increases in carbonate content at Eustis. On the basis of both the uppermost OSL ages in Peoria Loess reported by Roberts et al. (2003) and radiocarbon ages of the Brady Soil, Peoria Loess deposition ended sometime between ca. 14,000 and 12,000 cal yr B.P.

The ages of Peoria Loess deposition of ca. 26,000 cal yr B.P. to ca. 12,000 cal yr B.P. in Nebraska agree fairly closely with the inferred times of Peoria Loess deposition elsewhere in central North America. In eastern Colorado, radiocarbon ages suggest Peoria Loess deposi- 

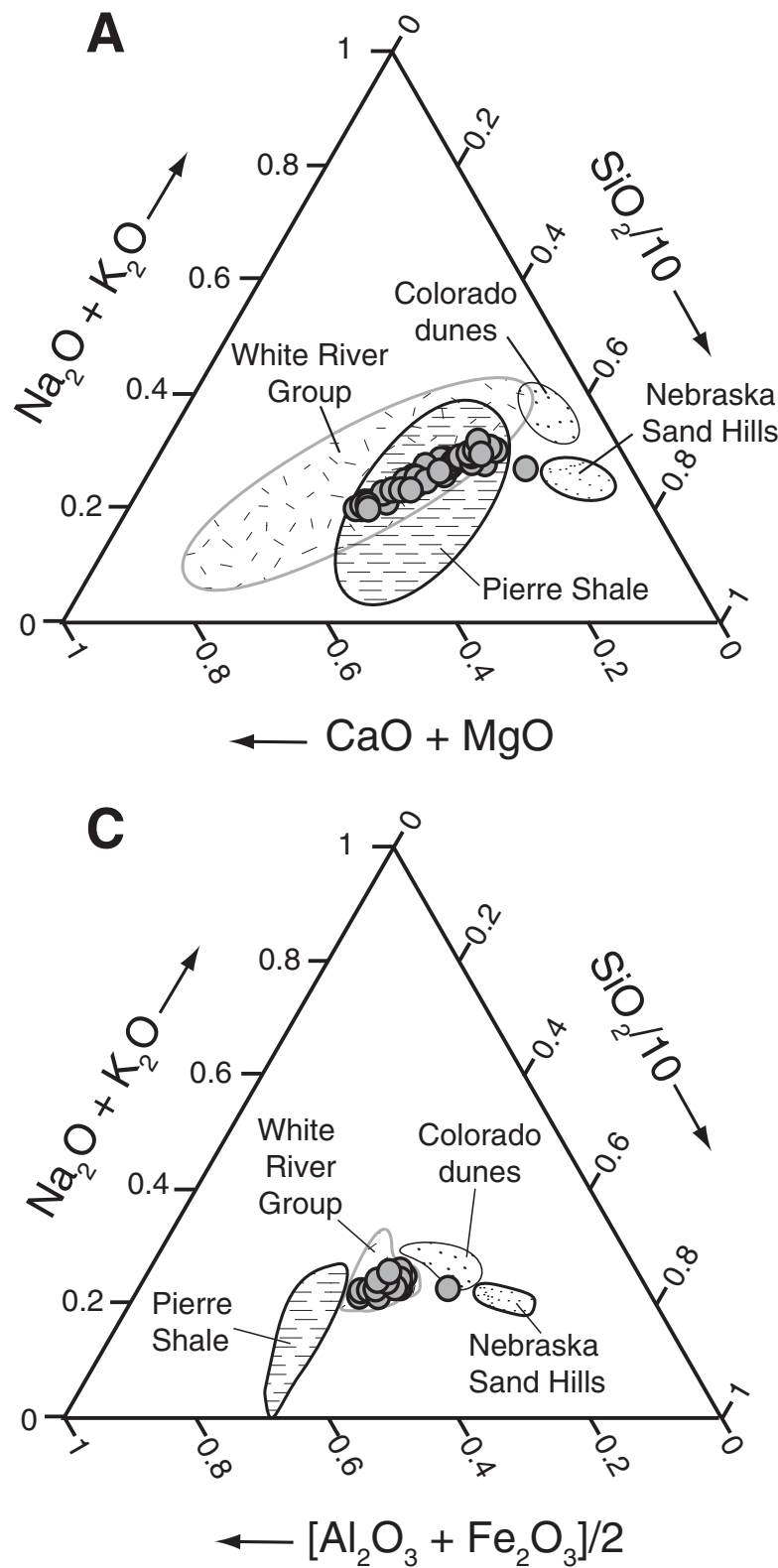
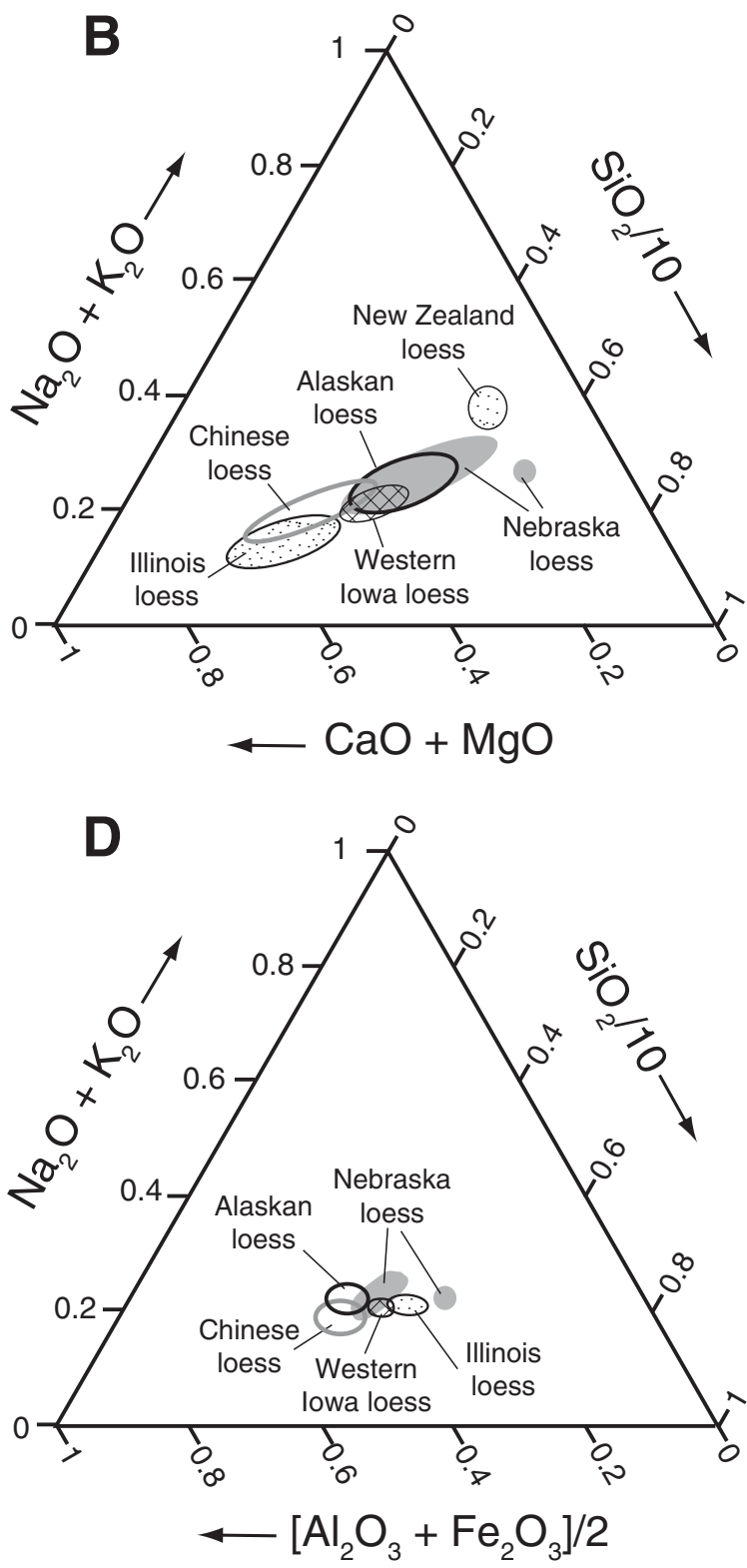

Figure 18. Ternary diagrams of major elements for Peoria Loess in Nebraska compared with potential source sediments (left) and loesses from other regions. Peoria Loess in Nebraska data from this study; Nebraska Sand Hills and Colorado dunes data from Muhs (2004); White River Group data from Dickinson (1994); Pierre Shale data from Schultz et al. (1980); Illinois and western Iowa loess data from Muhs and Bettis (2000) and Muhs et al. (2001); Alaskan loess data from Muhs et al. (2003a); Chinese loess data from Gallet et al. (1996) and Jahn et al. (2001); New Zealand loess data from Graham et al. (2001).

tion between ca. 25,000 and ca. 13,000 cal yr B.P. (Muhs et al., 1999). Bettis et al. (2003a) infer that loess deposition in western Iowa was in progress by no later than ca. 29,000 cal yr B.P. and had ended between ca. 16,000 and ca. 14,000 cal yr B.P. Studies by Grimley et al. (1998), Wang et al. (2003), and Muhs et al. (2001) indicate that Peoria Loess deposition in Illinois was in progress by ca. $29,000-25,000 \mathrm{cal}$ yr B.P. and continued until at least ca. 15,00013,000 cal yr B.P.
Thus, Peoria Loess, derived from diverse sources, has a remarkably similar chronology over an east-west distance of $>1000 \mathrm{~km}$ (Colorado to Illinois). Peoria Loess in Colorado was derived from alluvium that may have had an alpine glacier contribution plus Tertiary bedrock, whereas loess in Iowa and Illinois was ultimately derived mainly from outwash of the Laurentide ice sheet. Similar chronologies of loess deposition with different provenances suggest a common, climate-related forcing, a theme we return to after addressing the issue of sources of Peoria Loess in Nebraska.

\section{Potential Sources of Peoria Loess in Nebraska}

\section{Outwash from the Rocky Mountains via the Platte River System}

Bryan (1945), Swineford and Frye (1951), Winspear and Pye (1995), Pye et al. (1995), and Smalley (1995) all hypothesized or implied 


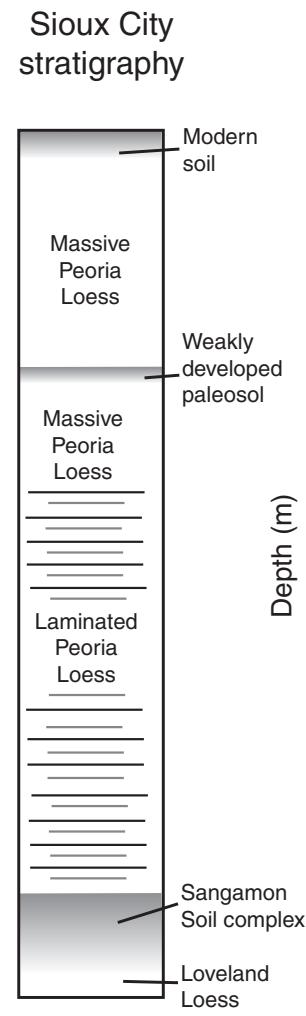

Coarse silt content (\%) $\begin{array}{llllll}50 & 55 & 60 & 65 & 70 & 75\end{array}$

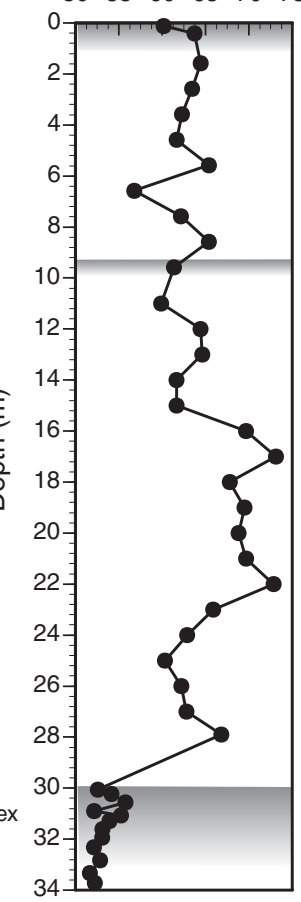

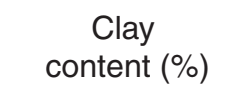
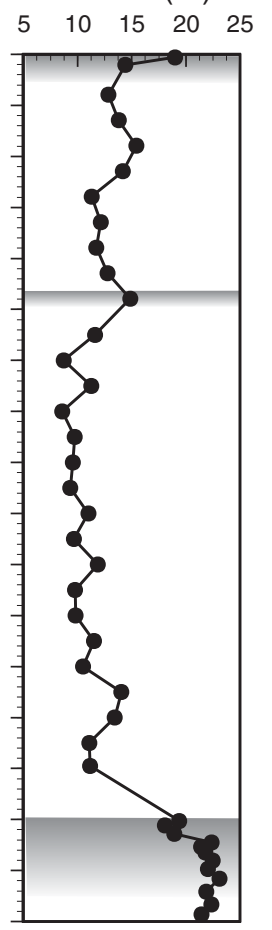

$\mathrm{K} / \mathrm{Rb}$

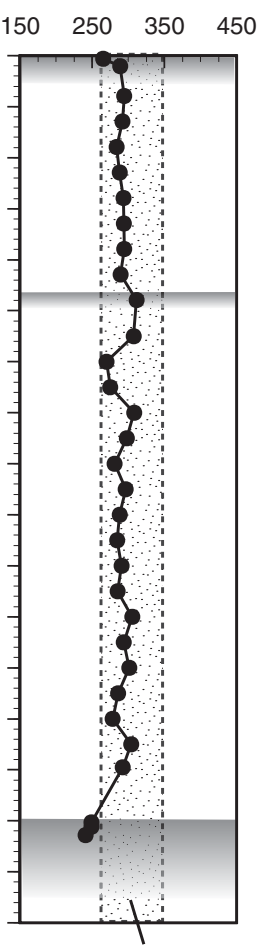

$\mathrm{Ti} / \mathrm{Nb}$

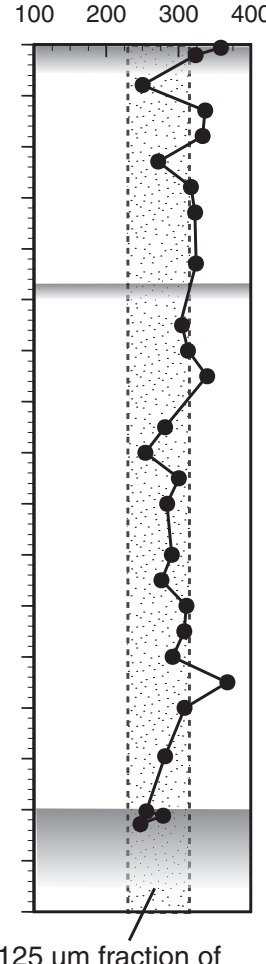

Range of values in $<125 \mu \mathrm{m}$ fraction of James Lobe and Des Moines Lobe tills

Figure 19. Stratigraphy, particle size, and geochemistry of the loess section at Sergeant Bluff, near Sioux City, Iowa.

that Peoria Loess in Nebraska was derived from glaciogenic silt of the Rocky Mountains via the Platte River system. The North Platte River drains the Sierra Madre and Medicine Bow Mountains of eastern Wyoming, which had small glaciers (Mears, 2001), but this river also drains the extensively glaciated east side of the Park Range of Colorado (Madole, 1991a, 1991b). Glaciers were also present in the Front Range of Colorado, drained by the South Platte River (Madole et al., 1998). Thus, a potentially important transport pathway for glaciogenic silt from the Rocky Mountains to Nebraska would have been via the Platte River, downstream of the confluence of the South Platte and North Platte Rivers (Fig. 2). Nevertheless, Flint (1971) questioned whether sufficient sediment could have been supplied via the Platte River system to explain the thick loess in Nebraska. Indeed, if the South Platte and Platte Rivers carried glaciogenic silt from the Rocky Mountains to Nebraska, thicker loess should have been deposited in Colorado, but this is not the case (Muhs et al., 1999). Furthermore, for Nebraska one might expect compositional differences between loess on the north and south sides of the Platte River system, unless opposing winds of approximately equal strength and duration had occurred throughout the last glacial period.

We do not consider the Platte River to have been a major source, because loess is compositionally identical on both sides of the Platte River system in Nebraska. Winspear and Pye (1995) also recognized the similar composition of loess on the north and south sides of the Platte River system in Nebraska. They hypothesized that this similarity could be explained by an ancestral Platte River of the last glacial period. In their model, this river flowed north of the loess that is presently north of the Platte River system. However, mapping by Swinehart et al. (1994a) shows that terrace deposits border the modern courses of the South Platte and Platte Rivers in Nebraska for $>600 \mathrm{~km}$, and some of these terraces are mantled with loess. Although the terrace deposits are not directly dated, basal radiocarbon ages of fan deposits that overlie the terrace deposits range from ca. 11,000 to ca. $12,400 \mathrm{cal}$ yr B.P. (Faulkner, 2002). These data indicate that the Platte River system was situated at or near its present location for at least the past $\sim 11,000$ cal $\mathrm{yr}$ and probably longer. Thus, it seems unlikely that the Platte River system had a significantly different course during the last glacial period. Locally, the Platte River system probably contributed some sediment to the loess bodies, a conclusion also reached by Mason (2001) and Aleinikoff et al. (2008), and inferred from the spatial variability in loess particle size presented herein. We conclude from all these considerations that loess in Nebraska, both north and south of the Platte River system, had a common source or sources that lay upwind of both loess bodies.

\section{Outwash from the Laurentide Ice Sheet via the Missouri River}

The Missouri River drained the Laurentide ice sheet and certainly was an important source of loess in western Iowa (Ruhe, 1969; Ruhe et al., 1971; Muhs and Bettis, 2000, 2003). The Missouri River has been hypothesized as a source of loess in Nebraska and Kansas by Bryan (1945), Swineford and Frye (1951), and Flint (1971, p. 259). The chronology of glacial advances in Iowa and South Dakota indicates that the Des Moines Lobe and the James Lobe were advancing southward (Bettis et al., 1996) during the time of maximum loess deposition in Nebraska, which permits the possibility of a glacial outwash source from the Missouri River. Distance 

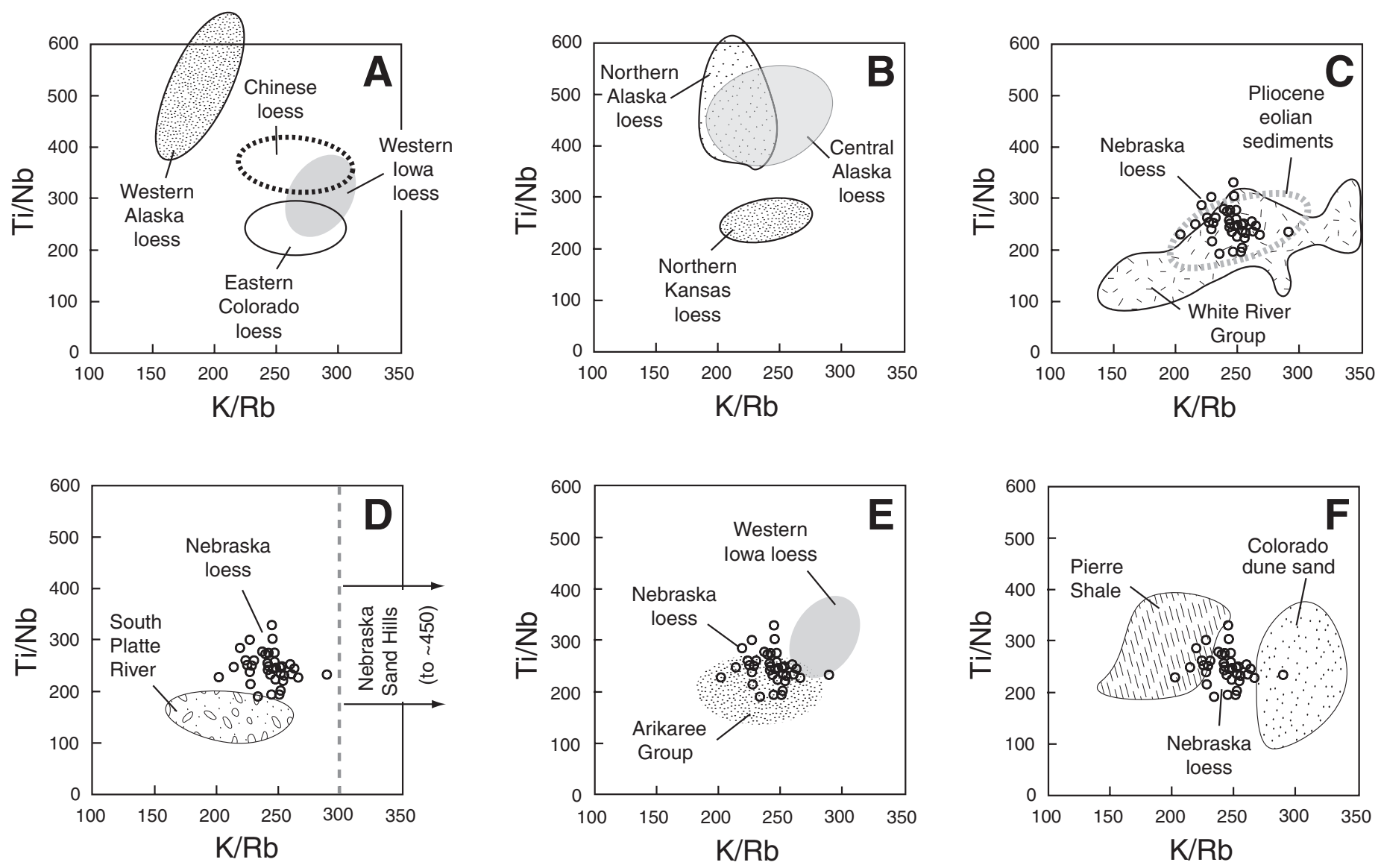

Figure 20. (A, B) K/Rb versus Ti/Nb for Peoria Loess from Iowa, Kansas, and Colorado and loess thought to date from the last glacial period in Alaska and China. Location and stratigraphic data sources are as follows: western Iowa (Sioux City, Fig. 19), and northern Kansas, this study; eastern Colorado, Muhs et al. (1999); central Alaska (Gold Hill and Halfway House), Muhs et al. (2003a); western Alaska (Seward Peninsula), Muhs et al. (2003b); northern Alaska (upper $4 \mathrm{~m}$ of a loess section near Kotzebue), this study. Chinese loess data are from Jahn et al. (2001) and Ding et al. (2001). (C, D, E, F) K/Rb versus Ti/Nb for Peoria Loess in Nebraska and various source sediments. Number of samples ( $n$ ) for source sediments: Nebraska Sand Hills $(n=60)$, Colorado dunes $(n=47)$, western Iowa loess $(n=33)$, White River Group $(\mathrm{n}=33)$, South Platte River $(\mathrm{n}=17)$, Pliocene sediments $(\mathrm{n}=18)$, Arikaree Group $(\mathrm{n}=11)$, Pierre Shale $(\mathrm{n}=12)$.

trends of $\mathrm{K} / \mathrm{Rb}, \mathrm{Ti} / \mathrm{Nb}$, and carbonate content indicate an influence of the Missouri River on Peoria Loess composition in northeastern Nebraska, within $\sim 30 \mathrm{~km}$ of the valley bluff line. However, even in those loess sections of eastern Nebraska that are adjacent to the Missouri River (Bellevue and Plattsmouth), there is evidence for only partial contributions from this source. Such local contributions, however, are also apparent in the thickness data of Swinehart et al. (1994a), Mason (2001), and Mason et al. (2007), and in the isotopic data of Aleinikoff et al. (2008).

\section{Nebraska Sand Hills}

The Nebraska Sand Hills and smaller, nearby dune fields have long been hypothesized to have played an important role for loess origins in Nebraska and Kansas (Lugn, 1939, 1968; Condra et al., 1947; Reed, 1968; Wright, 1970; Mason et al., 1999, 2003a; Mason, 2001; Miao et al., 2005, 2007; Jacobs and Mason, 2007).
The earliest studies were not specific about the role that this dune field might have played in loess genesis. More recent work, including that of Mason et al. (1999, 2003a), Mason (2001), and all later studies, have emphasized that dune fields can act as "surfaces of transport," whereby silt-sized particles can be brought into suspension by sand particles that are moving by saltation.

Nevertheless, many workers have argued that active dune fields can actually generate siltsized paricles, as well as transport them. Siltsized particles can, in principle, be generated from sand-sized particles under strong winds via abrasion and ballistic impacts on the basis of theoretical considerations as well as laboratory simulations and field evidence (Whalley et al., 1982; Dutta et al., 1993; Pye, 1995; Wright et al., 1998; Wright, 2001a, 2001b; Smith et al., 2002). Muhs et al. (1997) and Muhs (2004) point out that dune sand of the Nebraska Sand Hills is relatively mature mineralogically in comparison with most or all source sediments. One hypothesis for explaining these observations is size reduction of feldspars by ballistic impacts, resulting in quartz-sand enrichment (Dutta et al., 1993). Subsequent eolian deflation of silt-sized feldspars would then leave a quartz-sand-rich residue in the Nebraska Sand Hills. Experimental results also show that quartz-silt-particle production from sand particles via eolian abrasion is surprisingly efficient, although not as efficient as fluvial abrasion (Wright et al., 1998, their Table 3). Other workers have reported evidence for silt production in dune fields or in other sediments as a result of chemical weathering (Nahon and Trompette, 1982; Pye, 1983). However, these latter studies derive from observations of dune sand and other sediments in humid, tropical environments. 
Muhs et al.
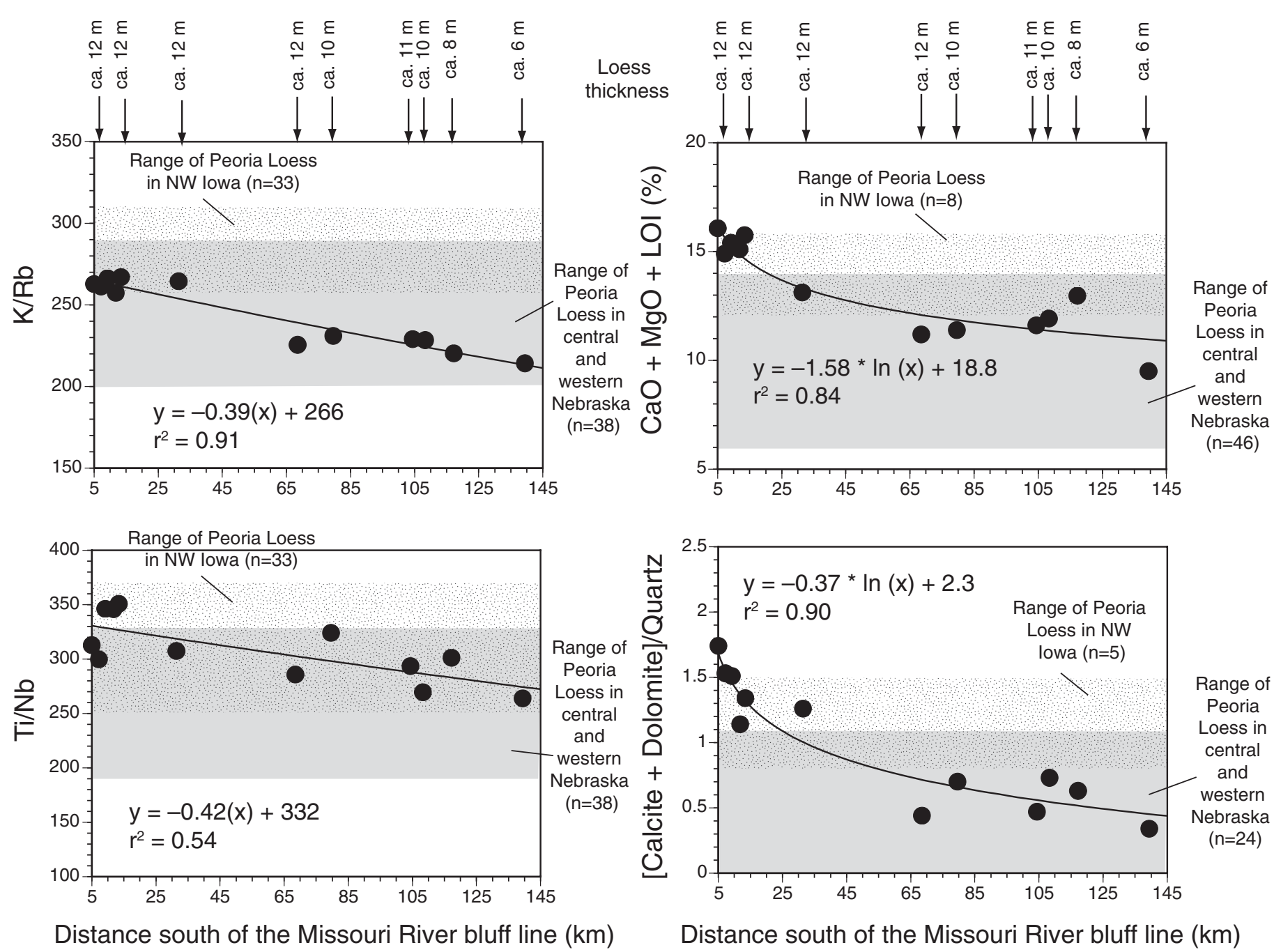

Figure 21. Geochemical and mineralogical data for loess in northeastern Nebraska, plotted as a function of distance south of the Missouri River bluff line (see Fig. 1 for transect location). Also shown are ranges of geochemical ratios for Peoria Loess in western Iowa (Sioux City locality; Fig. 1) and Peoria Loess in central and western Nebraska.

If the Nebraska Sand Hills had been an important particle contributor to the mass of Peoria Loess, there should be compositional similarities between Nebraska Sand Hills particles and loess. However, both mineralogy and geochemistry indicate little or no overlap in the composition of the Nebraska Sand Hills and Peoria Loess. Isotopic data from K-feldspars also indicate little influence from the Nebraska Sand Hills on loess composition (Aleinikoff et al., 2008). Contributions from the Nebraska Sand Hills are apparent in the particle size data presented here, but may have been limited to a very narrow band close to the dune field, where local enrichments of sandsized quartz took place.

\section{Pierre Shale (Cretaceous)}

Interestingly, most previous workers do not identify Pierre Shale as a particularly important source of loess. However, Pierre Shale occurs extensively upwind of Peoria Loess in Nebraska (Fig. 22), and our observations in northwestern Nebraska and southwestern South Dakota indicate that it is commonly free of overlying Quaternary sediments. Muhs et al. (1999) hypothesized that Pierre Shale may have been a contributor to the high clay content of some Peoria Loess in Colorado. Pierre Shale is rich in smectite (Schultz et al., 1980), also the dominant clay mineral in Peoria Loess of Nebraska. However, a more definitive mineralogical argument that supports a Pierre Shale contribution is the presence of dolomite. Dolomite was found in most Peoria Loess samples we analyzed, across the east-west extent of loess in Nebraska and on both sides of the Platte River. The presence of dolomite in loess on both sides of the Platte River and significantly west of the Mis- souri River precludes the rivers themselves as the only sources, based on paleowind considerations discussed earlier. Pierre Shale is the only other loess source of which we are aware that contains dolomite. However, with one exception, $\mathrm{K} / \mathrm{Rb}$ in Pierre Shale is $<230$, and most shale samples have $\mathrm{K} / \mathrm{Rb}<200$. In addition, most of the Pierre Shale samples we studied have $\mathrm{Ti} / \mathrm{Nb}>300$. These ratios fall outside the ranges of most Peoria Loess in Nebraska. Thus, we consider that Pierre Shale probably was a minor source of loess.

\section{Tertiary Siltstone (White River Group, Arikaree Group, Pliocene Beds)}

Geochemical evidence we have accumulated here and isotopic data in Aleinikoff et al. (2008) indicate to us that most loess in Nebraska is of nonglaciogenic origin, derived primarily from 


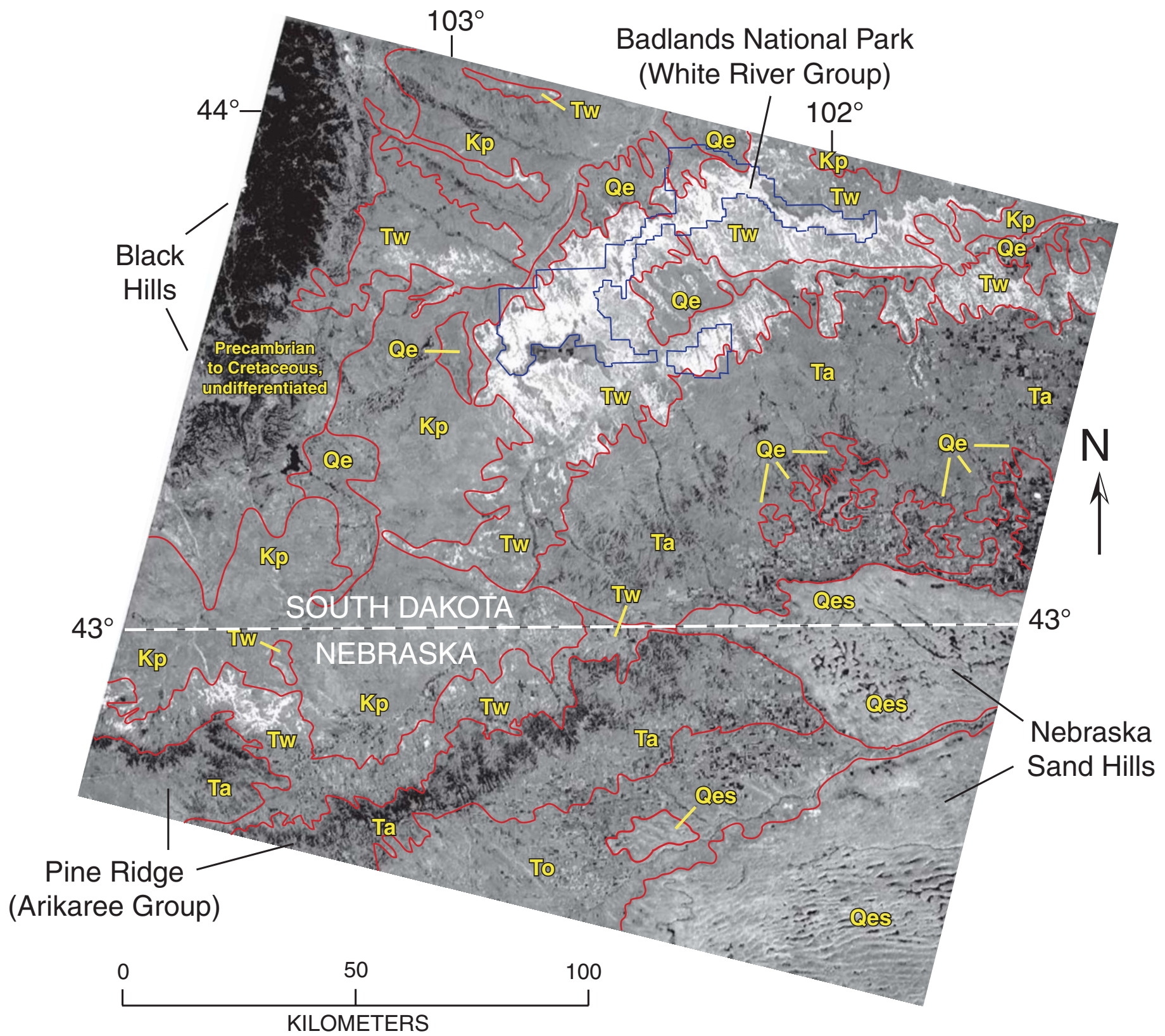

\author{
EXPLANATION \\ Qes: Eolian sand (Quaternary) \\ Qe: Eolian sand or silt (Quaternary) \\ To: Ogallala Group (Tertiary) \\ Ta: Arikaree Group (Tertiary) \\ Tw: White River Group (Tertiary) \\ Kp: Pierre Shale (Cretaceous)
}

Figure 22. Landsat 5 image (band 1, visible blue) of northern Nebraska and southern South Dakota, showing geographic features and possible source sediments for Peoria Loess in Nebraska. Also shown is a highly generalized geologic map of the area east of the Black Hills, compiled from Burchett (1986) and Martin et al. (2004). 
Tertiary siltstones and silt-rich sediments such as the White River Group, Arikaree Group, and the Pliocene beds. Of these, we favor the White River Group as the most important contributor. Arikaree Group rocks are, on average, much more lithified and less erodible than White River Group rocks. This characteristic explains, at least in part, why Arikaree Group rocks form the prominent upland of the Pine Ridge area, whereas rocks of the White River Group form the lower-elevation Badlands area (Fig. 22). Furthermore, particle size analyses by Sato and Denson (1967) show that sediments of the White River Group are much more siltrich $(\sim 77 \%-68 \%)$ than are rocks of the Arikaree Group $(\sim 32 \%)$. It is also worth noting that Jacobs and Mason (2007) report that the glass content of deep Peoria Loess is low ( $5 \%-18 \%)$ in comparison with the glass content of the White River Group ( $53 \%$ ) or even the Arikaree Group ( 28\%), at least in the very fine sand fractions (Swinehart et al., 1985). If these data are also representative of the silt fractions as well as the most easily eroded facies of these rocks in general, they suggest that neither the White River Group nor the Arikaree Group rocks are sole sources of Peoria Loess in Nebraska. On the other hand, glass particles could be easily reduced in size during transport by saltation, which complicates matters. Mason (2001) pro- poses the silt-rich facies of the Pliocene beds as a potential source, and our geochemical results and the isotopic results of Aleinikoff et al. (2008) show that this is a possibility, which we discuss in more detail below.

\section{Evaluation of Loess Transport Pathway Models}

Our studies of Peoria Loess in Nebraska support one of the models presented by Mason (2001), who distinguished the "immediate" source of loess from the "ultimate" source of loess in this model. The immediate source of loess in this context is the geographic area where particles were last entrained before deposition in the present loess body. The ultimate source of loess refers to provenance, i.e., the rock or sediment body where the particles originated before transport. The Nebraska Sand Hills may be the immediate source of the loess, but the ultimate source or sources lay northward, primarily in the erodible rocks of Pierre Shale, the White River Group, the Arikaree Group, and Pliocene eolian sediments (Fig. 22). With Cretaceous and Tertiary rocks as the ultimate source of the loess, and the Nebraska Sand Hills as the immediate source, there is an analogy with the glaciated part of the North American Midcontinent. In this region, glacial tills were the most important ultimate source of the loess particles, but river valleys that drained the glaciers were the immediate source (Grimley, 2000).

The mineralogical, geochemical, and isotopic data presented here and in Aleinikoff et al. (2008) show that the Nebraska Sand Hills region, despite its importance as an immediate source, has probably added little mass to the loess in Nebraska other than addition of quartz-dominated sand to a narrow zone directly downwind of the dunes. Nevertheless, the relatively coarse texture of Peoria Loess in Nebraska, as demonstrated by high amounts of coarse silt, suggests that much of the silt transport was not likely to have taken place in high suspension over hundreds of kilometers (Pye, 1987). As outlined by Mason (2001), however, cumulative long-distance transport of coarse silts in low suspension could have taken place through a series of relatively short transport events from distal outcrops of the Tertiary rocks and sediments, through the Nebraska Sand Hills, and ultimately to the loess hills and plains in the southeastern half of Nebraska (Fig. 23). If the Nebraska Sand Hills was an active dune field during the last glacial period, as some evidence seems to indicate (Loope et al., 1995; Muhs et al., 2000; Goble et al., 2004), silt particles could have been kept in suspension easily because saltating sand grains would have re-suspended silt grains at the surface. Impact threshold shear

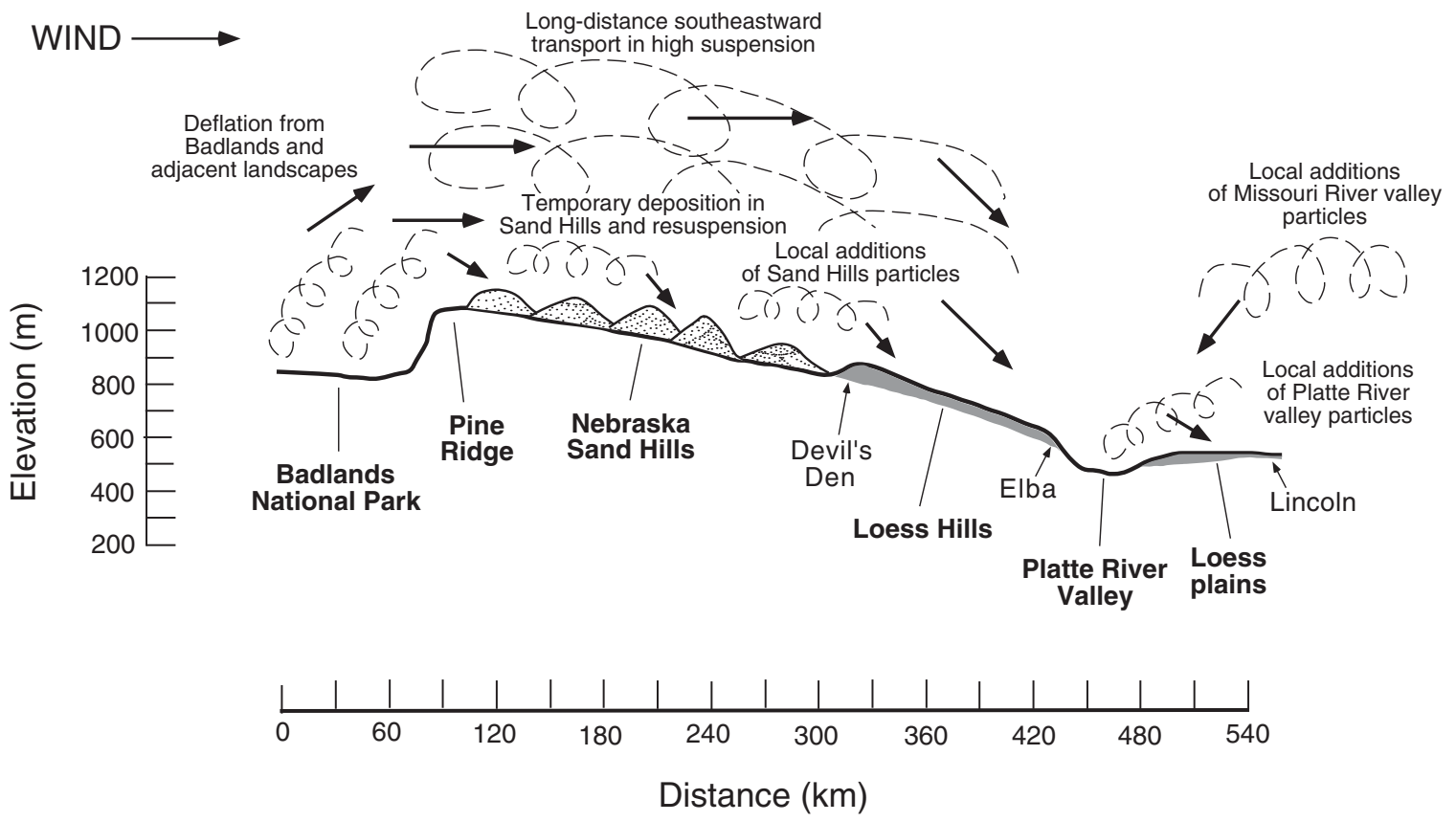

Figure 23. Model for loess sources, transport pathways, and loci of deposition in Nebraska, schematized from Mason (2001). 
velocities for fine particles are much lower than fluid threshold shear velocities (Pye, 1987). Thus, even modest wind velocities in an active dune field could keep coarse silt particles in motion such that cumulative transport distances could amount to hundreds of kilometers. Fine particle coatings and bands ("clay lamellae"), common in the Nebraska Sand Hills, may be remnants of past silt and clay transport through this large dune field.

It is more difficult to evaluate Mason's (2001) hypothesis of Pliocene beds in Nebraska as a source of loess. $\mathrm{K} / \mathrm{Rb}$ and $\mathrm{Ti} / \mathrm{Nb}$ in Peoria Loess of Nebraska overlap those in the silt and fine sand fraction of the Pliocene beds, which certainly permits this possibility. More importantly, $\mathrm{Pb}$ isotopic compositions of K-feldspars in Peoria Loess and Pliocene silts overlap (Aleinikoff et al., 2008). Mineralogical data suggest, however, that the Pliocene beds are not likely to have been the only source, as they lack dolomite and have little or no calcite, whereas both these minerals occur in Peoria Loess. Mason (May 2007, written commun.) suggested a variation on his original hypothesis, which is that Pliocene beds supplied both sand to the Nebraska Sand Hills and silt to Peoria Loess. This intriguing possibility can be evaluated with isotopic, mineralogical, and geochemical data. If Pliocene beds also supplied sand to the Nebraska Sand Hills, there should be compositional similarities. However, the $\mathrm{Pb}$ isotopic composition of sand-sized K-feldspars from the Pliocene beds has only minimal overlap with that of sand-sized K-feldpars in the Nebraska Sand Hills (Aleinikoff et al., 2008). Furthermore, Nebraska Sand Hills sands are much more mature mineralogically than sands in the Pliocene beds (Muhs et al., 1997; Muhs, 2004). Differences in mineralogical maturity do not, per se, rule out a genetic relation between two sand bodies. However, in this case the degree of maturity of the Nebraska Sand Hills suggests a longer history than that of the period of deposition of Peoria Loess. Thus, we favor Mason's (2001) first model.

\section{“Glacial” Loess and “Desert” Loess}

There has been considerable debate over the concepts of "glacial" loess versus "desert" (i.e., nonglacial) loess (see reviews in Pye, 1987, 1995; Tsoar and Pye, 1987; Livingstone and Warren, 1996; Muhs and Bettis, 2003). Glacial loess is considered to be eolian particles that have been reduced to silt size primarily by glacial grinding. Desert loess is eolian sediment whose silt-sized particles were produced dominantly by other processes. Some investigators, particularly I.J. Smalley and coworkers, argue that glacial grinding is the only mechanism that can produce significant amounts of silt-sized particles (Smalley, 1966, 1995; Smalley and Vita-Finzi, 1968; Smalley and Krinsley, 1978). Other researchers conclude that silt-sized particles can be produced by a variety of processes, including frost weathering, salt weathering, chemical weathering, and fluvial and eolian comminution (Nahon and Trompette, 1982; Whalley et al., 1982; McTainsh, 1987; Dutta et al., 1993; Wright et al., 1998; Wright, 2001a, 2001b; Smith et al., 2002).

In the glacial-loess-versus-desert-loess debate, there is little or no mention of silt particle inheritance from sedimentary rocks. Notable exceptions to this are studies in Argentina, where an Andean volcaniclastic source has been recognized (Zárate and Blasi, 1993), and Australia, where siltstones may be the ultimate source of much of the silt-sized dust in arid basins (McTainsh, 1989). Silt is abundant in the sedimentary rock record. Indeed, Blatt (1987) estimates that fully half of the detrital quartz in the world's sedimentary rocks consists of siltsized particles. In the case of Peoria Loess in the Great Plains of Nebraska, our data and those of Aleinikoff et al. (2008) indicate that sedimentary rock is probably the most important source of silt-sized particles.

\section{Comparison of Loess Records in Nebraska with Paleoclimate Models}

One of the most remarkable features of the last glacial period is that the Earth was a dustier planet. There are good records of greater eolian particle transport and accumulation during the last glacial period in the deep ocean and in polar ice caps (see reviews in Mahowald et al., 1999; Kohfeld and Harrison, 2000, 2001; Harrison et al., 2001; Kohfeld and Tegen, 2007). Mahowald et al. (1999) summarized the hypothesized causes of the last glacial increases in dust flux and accumulation. These include higher wind velocities, a reduced intensity of the hydrological cycle (thus allowing dust to stay in transit longer), and reduced soil moisture and vegetation cover in source regions. Increased glaciogenic silt can be added to this, but does not apply to Nebraska, on the basis of results shown here.

Numerous attempts have been made to model the generation, transport, and deposition of dust on a global scale, both for modern conditions and the last glacial period, summarized by Harrison et al. (2001). Early models attempted to simulate last glacial dust production using changes in wind intensity and the hydrological cycle only and did not succeed in reproducing the observed last-glacial increases in dust accumulation in ice cores and deep-sea cores. A later model incorporated all of the earlier factors plus decreased soil moisture and increased source areas, owing to changes in vegetation type and amount of cover (Mahowald et al., 1999). Better agreement of this study's results with the geologic record confirmed that climate change alone (wind strength and intensity of the hydrologic cycle) was insufficient to simulate the observed increases in dust. Nevertheless, the results of Mahowald et al. (1999) showed some disagreements with geologic records as well. Central North America in the 1999 model does not appear as a significant source of dust during the last glacial period. However, a refined version of the model used by Mahowald et al. (1999) shows that the northern Great Plains region of central North America could indeed have been a significant source of nonglacial loess during the last glacial period (see Mahowald et al., 2006, their Fig. 8a). Results of the present study and the companion paper by Aleinikoff et al. (2008) are in agreement with these new results.

Results of the present study, as well as those of Swinehart et al. (1994a) and Mason (2001), indicate paleowinds from the northwest in Nebraska during the last glacial period. A mesoscale model (Polar MM5) presented by Bromwich et al. (2005) sheds some new light on paleowinds in midcontinental North America during the last glacial period. Polar MM5 is attractive for modeling paleowinds above and near the Laurentide ice sheet during the last glacial period, because the model has simulated modern katabatic winds over Greenland successfully (Bromwich et al., 2001). Results of summer climate simulations from Polar MM5 for the last glacial period in North America indicate easterly and northeasterly katabatic winds near the ice sheet (Bromwich et al., 2005). However, the zone affected by katabatic winds is limited to an area within a few model grid points (estimated to be less than $\sim 200 \mathrm{~km}$ ) south of the ice sheet. In the areas to the south of this zone, winds are simulated to have been much more variable with a greater frequency of westerly winds. Mahowald et al. (2006) simulated west to east transport of dust during the last glacial period in their model, in good agreement with the loess record. However, these investigators also pointed out that easterly winds were the average condition (i.e., during less dusty periods) during the last glacial period (Mahowald et al., 2006, p. 17). It is possible that the average, easterly winds of the last glacial period apply to a zone fairly close to the Laurentide ice sheet. Much of the area where Peoria Loess was deposited in Nebraska is greater than $200 \mathrm{~km}$ south of the ice sheet (Fig. 1). Therefore, some of the apparent conflict in loess paleowinds versus climate models, noted by Muhs and Bettis (2000), is not a failure of the models nor a misinterpretation of the loess records but a question of scale and geography. 


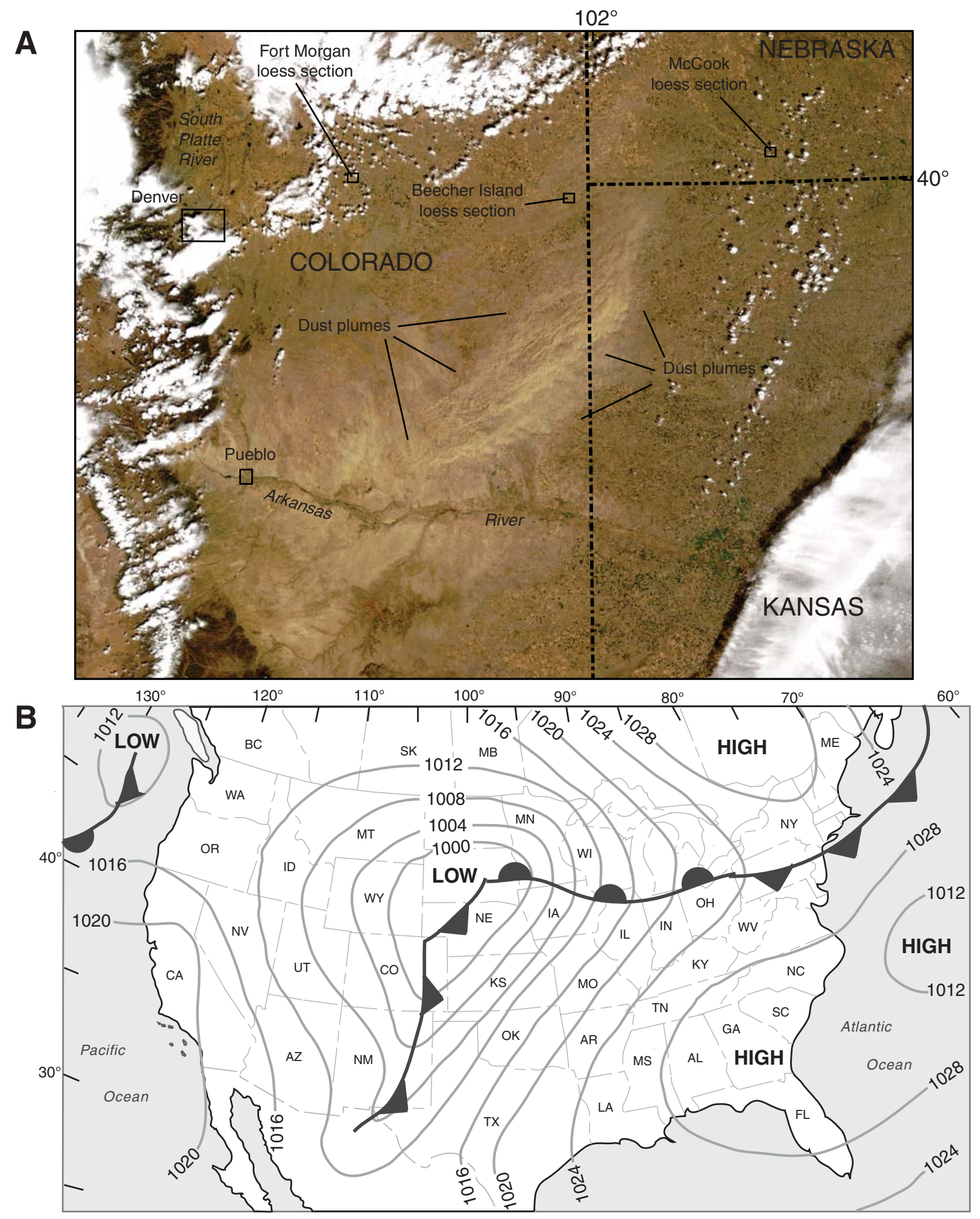

Figure 24. (A) MODIS image acquired aboard the Terra satellite on 18 April 2004, showing dust plumes in eastern Colorado, western Kansas, and southern Nebraska, which developed from high-velocity winds under the influence of a strong low-pressure system and cold front. Image courtesy of NASA and Liam Gumley, Space Science and Engineering Center, University of Wisconsin, Madison. Accessed from http://earthobservatory.nasa.gov; image identification is 12078. Also shown are the three westernmost loess sections studied or referred to herein. (B) Synoptic-scale weather conditions showing isobars (gray lines), major fronts, and high- and low-pressure centers over the United States on 18 April 2004, when the dust plumes in panel A were imaged by MODIS. Map redrawn from NOAA archives at http://www.hpc. ncep.noaa.gov/dailywxmap/index.html. MODIS—moderate resolution imaging spectroradiometer. 
In addition, however, both Bromwich et al. (2005, p. 3334) and Mahowald et al. (2006, p. 17) note that frequency, magnitude, and seasonality of loess transportation may also be factors, a hypothesis also suggested by Muhs and Bettis (2000). In the Polar MM5 model presented by Bromwich et al. (2005), precipitation in the central Great Plains is simulated to have been dominant in summer, a situation that would not enhance loess particle entrainment or transport during this season. Increased interannual variability may have played a role, with some summers having been drier than others (Bromwich et al., 2005). On average, however, Polar MM5 simulates springtime (March through May) to have been relatively dry during the last glacial period. Furthermore, the last-glacial spring seasons in the Great Plains are simulated to have experienced occasional passage of synopticscale low-pressure systems. In Polar MM5, these low-pressure systems have little precipitation associated with them but are characterized by high-velocity winds at lower levels. Moreover, this springtime cyclonic circulation would have converged with the katabatic wind flow from the Laurentide ice sheet, enhancing vertical particle motion to levels at which westerly winds were dominant. Bromwich et al. (2005) point out that springtime would have been warm enough for source sediments to thaw, but also a time before the summer precipitation maximum. The scenario proposed by Bromwich et al. (2005) may also explain the similar chronology of loess deposition in the Great Plains and Iowa and Illinois, farther east, because both areas would have been affected by similar synoptic-scale conditions during springtime. A spring dust storm in eastern Colorado, on 18 April 2004, was caused by strong winds associated with a low-pressure system but no rain (Fig. 24). This may be a modern analog for the Bromwich et al. (2005) model for the last glacial period.

\section{CONCLUSIONS}

Peoria Loess is extensive and thick in the central Great Plains region of Nebraska. Radiocarbon and OSL ages indicate that Peoria Loess was deposited during the last glacial period, ca. 25,000 to ca. 13,000 cal yr B.P., similar to other parts of North America. In some parts of central and western Nebraska, loess thicknesses are great, mass accumulation rates were high, and geochemical proxies for carbonate content were also high, indicating little or no syndepositional leaching.

Particle size trends (sand, fine silt, and clay) indicate that paleowinds from the northwest deposited Peoria Loess in Nebraska during the last glacial period. The sedimentological trends indicate that the source or sources of Peoria Loess in Nebraska lay to the northwest of the main loess body, in agreement with thickness data and inferred paleowinds presented by Mason (2001).

Mineralogical and geochemical data indicate that the main sources of loess in Nebraska were probably the White River Group, the Arikaree Group, Pliocene sediments, and perhaps Pierre Shale. These data are consistent with complementary isotopic data presented in a companion paper (Aleinikoff et al., 2008). The Platte River system and the Nebraska Sand Hills, long thought to have been the sources of Peoria Loess, probably added very little to the accumulation of loess except in immediately adjacent areas. A model presented by Mason (2001), however, shows that the Nebraska Sand Hills probably served an important function as a sediment transport pathway, allowing relatively coarse loess to be transported hundreds of kilometers from its source region. Our studies agree with this sequence of events. The Missouri River may have provided some glaciogenic silt to localities immediately west or south of the river, but little elsewhere in the state.

Previous climate-dust models did not simulate significant dust generation in the northern Great Plains during the last glacial period. However, a refined model presented by Mahowald et al. (2006) does simulate a significant northern Great Plains dust source, in agreement with our results. A mesoscale paleoclimate model for North America presented by Bromwich et al. (2005) suggests that Peoria Loess in Nebraska may have been deposited by westerly winds as low-pressure systems passed south of the Laurentide ice sheet during relatively dry spring seasons. Our results are consistent with this model, and satellite observations suggest that the process may occur even today.

\section{ACKNOWLEDGMENTS}

This work was supported by the Earth Surface Dynamics Program of the U.S. Geological Survey (to USGS and University of Wales authors) and by U.S. National Science Foundation grant EAR-00-87572 (to Bettis). This is a contribution to the USGS project "Eolian History of North America" and to the DIRTMAP project. Our thanks go to the landowners of the various localities we studied: Eldon Hawes (Fort Morgan, Colorado); Jerry Coyle (McCook, Nebraska); Bonnie and Kent Hueftle (Eustis, Nebraska); Ken Wehrman (Devil's Den, Nebraska); Rod and Sandy Ansley (Red Ranch, Nebraska); and the Sioux City Brick Company (Sioux City, Iowa). We appreciate helpful discussions, in and out of the field, with Tom Ager, Dave Bromwich, Karen Kohfeld, Natalie Mahowald, Ann Wintle, Geoff Duller, Alan Busacca, Joe Mason, and Jim Swinehart. Jim Swinehart kindly provided a copy of Myers' (1993) sand sheet map. We thank Carrie Jennings (University of Minnesota), Joe Mason (University of Wisconsin),
Natalie Mahowald (Cornell University), David Bromwich (Ohio State University), Howard Hobbs (Minnesota Geological Survey), Randy Schaetzl (Michigan State University), Christoph Geiss (Trinity College), David Grimley (Illinois State Geological Survey), and Kathleen Simmons (USGS) for helpful comments on an earlier version of the paper.

\section{REFERENCES CITED}

Aleinikoff, J.N., Muhs, D.R., and Fanning, C.M., 1998, Isotopic evidence for the sources of late Wisconsin (Peoria) loess, Colorado and Nebraska: Implications for paleoclimate, in Busacca, A., ed., Dust aerosols, loess soils and global change: Pullman, Washington State University, College of Agriculture and Home Economics Miscellaneous Publication MISC0190, p. 124-127.

Aleinikoff, J.N., Muhs, D.R., Sauer, R.R., and Fanning, C.M., 1999, Late Quaternary loess in northeastern Colorado: Part II- $\mathrm{Pb}$ isotopic evidence for the variability of loess sources: Geological Society of America Bulletin, v. 111, p. 1876-1883, doi: 10.1130/0016-760 6(1999) $111<1876$ :LQLINC>2.3.CO;2.

Aleinikoff, J.N., Muhs, D.R., Bettis, E.A., III, Johnson, W.C., Benton, R., and Fanning, C.M., 2008, Isotopic evidence for the diversity of late Quaternary loess in Nebraska: Glacial and non-glacial sources

Bettis, E.A., III, Quade, D.J., and Kemmis, T.J., 1996, Hogs, bogs, and logs: Quaternary deposits and environmental geology of the Des Moines Lobe: Iowa Department of Natural Resources, Geological Survey Bureau Guidebook Series no. 18, 170 p.

Bettis, E.A., III, Muhs, D.R., Roberts, H.M., and Wintle, A.G., 2003a, Last glacial loess in the conterminous U.S.A.: Quaternary Science Reviews, v. 22, p. 1907-1946, doi: 10.1016/S0277-3791(03)00169-0.

Bettis, E.A., III, Mason, J.P., Swinehart, J.B., Miao, X., Hanson, P.R., Loope, D.B., Jacobs, P.M., and Roberts, H.M., 2003b, Cenozoic eolian sedimentary systems of the USA mid-continent, in Easterbrook, D.J., ed., Quaternary geology of the United States: Reno, Nevada, Desert Research Institute, INQUA 2003 Field Guide Volume, p. 195-218.

Blatt, H., 1987, Oxygen isotopes and the origin of quartz: Journal of Sedimentary Petrology, v. 57, p. 373-377.

Bromwich, D.H., Cassano, J.J., Klein, T., Heinemann, G., Hines, K.M., Steffen, K., and Box, J.E., 2001, Mesoscale modeling of katabatic winds over Greenland with the Polar MM5: Monthly Weather Review, v. 129 , p. $2290-2309$, doi: $10.1175 / 1520-0493(2001) 1$ 29<2290:MMOKWO>2.0.CO;2.

Bromwich, D.H., Toracinta, E.R., Oglesby, R.J., Fastook, J.L., and Hughes, T.J., 2005, LGM summer climate on the southern margin of the Laurentide Ice Sheet: Wet or dry?: Journal of Climate, v. 18, p. 3317-3338, doi: 10.1175/JCLI3480.1.

Bryan, K., 1945, Glacial versus desert origin of loess: American Journal of Science, v. 243, p. 245-248.

Burchett, R.R., 1986, Geologic bedrock map of Nebraska: Nebraska Geological Survey GMC-1, scale 1:1,000,000, 1 sheet.

Condra, G.E., Reed, E.C., and Gordon, E.D., 1947, Correlation of the Pleistocene deposits of Nebraska: Nebraska Geological Survey Bulletin 15, 73 p.

Dickinson, K.A., 1994, Preliminary chemical and mineralogical analyses of the major volcanic ash beds in the Oligocene Brule Formation, northwestern Nebraska: U.S. Geological Survey Open-File Report 94-292, 36 p.

Ding, Z.L., Sun, J.M., Yang, S.L., and Liu, T.S., 2001, Geochemistry of the Pliocene red clay formation in the Chinese Loess Plateau and implications for its origin, source provenance and paleoclimate change: Geochimica et Cosmochimica Acta, v. 65, p. 901-913, doi: 10.1016/S0016-7037(00)00571-8.

Dreimanis, A., 1962, Quantitative gasometric determination of calcite and dolomite by using Chittick apparatus: Journal of Sedimentary Petrology, v. 32, p. 520-529.

Dutta, P.K., Zhou, Z., and dos Santos, P.R., 1993, A theoretical study of mineralogical maturation of eolian sand, in Johnsson, M.J., and Basu, A., eds., Processes controlling the composition of clastic sediments: Geological Society of America Special Paper 284, p. 203-209. 
Fairbanks, R.G., Mortlock, R.A., Chiu, T.-C., Cao, L., Kaplan, A., Guilderson, T.P., Fairbanks, T.W., Bloom, A.L., Grootes, P.M., and Nadeau, M.-J., 2005, Radiocarbon calibration curve spanning 0 to 50,000 years BP based on paired ${ }^{230} \mathrm{Th} /{ }^{234} \mathrm{U} /{ }^{238} \mathrm{U}$ and ${ }^{14} \mathrm{C}$ dates on pristine corals: Quaternary Science Reviews, v. 24 p. 1781-1796, doi: 10.1016/j.quascirev.2005.04.007.

Faulkner, D.J., 2002, Alluvial fans as records of Holocene sediment yield in the central Great Plains of southwest Nebraska: Physical Geography, v. 23, p. 343-365, doi: 10.2747/0272-3646.23.5.343

Feng, Z.-D., and Khosbayar, P., 2004, Paleosubarctic eolian environments along the southern margin of the North American icesheet and the southern margin of Siberia during the last glacial maximum: Palaeogeography, Palaeoclimatology, Palaeoecology, v. 212, p. 265-275, doi: 10.1016/j.palaeo.2004.06.004

Flint, R.F., 1971, Glacial and Quaternary geology: New York, Wiley \& Sons, $906 \mathrm{p}$

Frye, J.C., and Leonard, A.B., 1951, Stratigraphy of the late Pleistocene loesses of Kansas: Journal of Geology, v. 59 , p. $287-305$.

Fullerton, D.S., Bush, C.A., and Pennell, J.N., 2003, Map of surficial deposits and materials in the eastern and central United States (east of 102 degrees west longitude): U.S. Geological Survey Miscellaneous Investigations Series Map I-2789, scale 1:2,500,000, 1 sheet.

Fullerton, D.S., Colton, R.B., Bush, C.A., and Straub, A.W., 2004, Map showing spatial and temporal relations of mountain and continental glaciations on the northern plains, primarily in northern Montana and northwestern North Dakota: U.S. Geological Survey Scientific Investigations Map 2843, scale 1:1,000,000, 1 sheet.

Gallet, S., Jahn, B., and Torii, M., 1996, Geochemical characterization of the Luochuan loess-paleosol sequence, China, and paleoclimatic implications: Chemical Geology, v. 133, p. 67-88, doi: 10.1016 S0009-2541(96)00070-8

Goble, R.J., Mason, J.A., Loope, D.B., and Swinehart, J.B., 2004, Optical and radiocarbon ages of stacked paleosols and dune sands in the Nebraska Sand Hills, USA Quaternary Science Reviews, v. 23, p. 1173-1182, doi: 10.1016/j.quascirev.2003.09.009.

Graham, I.J., Ditchburn, R.G., and Whitehead, N.E., 2001 , Be isotope analysis of a 0-500 ka loess-paleosol sequence from Rangitatau East, New Zealand: Quaternary International, v. $76-77$, p. $29-42$, doi: $10.1016 /$ S1040-6182(00)00087-2.

Grimley, D.A., 2000, Glacial and nonglacial sediment contributions to Wisconsin Episode loess in the centra United States: Geological Society of America Bulletin, v. 112, p. 1475-1495, doi: 10.1130/0016-7606(2000) $12<1475$ :GANSCT $>2.0 . \mathrm{CO} ; 2$

Grimley, D.A., Follmer, L.R., and McKay, E.D., 1998, Mag netic susceptibility and mineral zonations controlled by provenance in loess along the Illinois and centra Mississippi River valleys: Quaternary Research, v. 49, p. 24-36, doi: 10.1006/qres.1997.1947.

Hallberg, G.R., and Kemmis, T.J., 1986, Stratigraphy and correlation of the glacial deposits of the Des Moines and Jame lobes and adjacent areas in North Dakota, South Dakota, Minnesota, and Iowa: Quaternary Science Reviews, v. 5 , p. 65-68, doi: 10.1016/0277-3791(86)90175-7.

Handy, R.L., 1976, Loess distribution by variable winds: Geological Society of America Bulletin, v. 87, p. 915-927, doi: 10.1130/0016-7606(1976)87<915:L DBVW>2.0.CO;2.

Harrison, S.P., Kohfeld, K.E., Roelandt, C., and Claquin, T., 2001, The role of dust in climate changes today, at the last glacial maximum and in the future: EarthScience Reviews, v. 54, p. 43-80, doi: 10.1016 S0012-8252(01)00041-1.

Heier, K.S., and Adams, J.A.S., 1964, The geochemistry of the alkali metals: Physics and Chemistry of the Earth, v. 5 , p. 253-381, doi: 10.1016/S0079-1946(64)80007-0.

Jacobs, P.M., and Mason, J.A., 2007, Late Quaternary climate change, loess sedimentation, and soil profile development in the central Great Plains: A pedosedimentary model: Geological Society of America Bulletin, v. 119 , p. 462-475, doi: 10.1130/B25868.1.

Jahn, B., Gallet, S., and Han, J., 2001, Geochemistry of the Xining, Xifeng and Jixian sections, Loess Plateau of China: Eolian dust provenance and paleosol evolu- tion during the last $140 \mathrm{ka}$ : Chemical Geology, v. 178 p. 71-94, doi: 10.1016/S0009-2541(00)00430-7.

Johnson, W.C., and Willey, K.L., 2000, Isotopic and rock magnetic expression of environmental change at the Pleistocene-Holocene transition in the central Great Plains: Quaternary International, v. 67, p. 89-106, doi 10.1016/S1040-6182(00)00011-2.

Johnson, W.C., Willey, K.L., Mason, J.A., and May, D.W., 2007, Stratigraphy and environmental reconstruction at the middle Wisconsinan Gilman Canyon Formation type locality, Buzzard's Roost, southwestern Nebraska, USA: Quaternary Research, v. 67, p. 474-486, doi 10.1016/j.yqres.2007.01.011.

Kohfeld, K.E., and Harrison, S.P., 2000, How well can we simulate past climates? Evaluating the models using global paleoenvironmental datasets: Quaternary Science Reviews, v. 19, p. 321-346, doi: 10.1016/ S0277-3791(99)00068-2.

Kohfeld, K.E., and Harrison, S.P., 2001, DIRTMAP: The geological record of dust: Earth-Science Reviews, v. 54 p. 81-114, doi: 10.1016/S0012-8252(01)00042-3.

Kohfeld, K.E., and Tegen, I., 2007, Record of mineral aerosols and their role in the Earth system, in Holland, H.D., and Turekian, K.K., eds., Treatise on geochemistry: New York, Elsevier, http://www.sciencedirect. com/science/referenceworks/9780080437514, $26 \mathrm{p}$.

Lange, I.M., Reynolds, R.C., and Lyons, J.B., 1966, K $\mathrm{Rb}$ ratios in coexisting K-feldspars and biotites from some New England granites and metasediments: Chemical Geology, v. 1, p. 317-322, doi 10.1016/0009-2541(66)90027-1.

Livingstone, I., and Warren, A., 1996, Aeolian geomorphology: Essex, UK, Addison-Wesley-Longman, $211 \mathrm{p}$

Loope, D.B., Swinehart, J.B., and Mason, J.P., 1995, Dunedammed paleovalleys of the Nebraska Sand Hills: Intrinsic versus climatic controls on the accumulation of lake and marsh sediments: Geological Society of America Bulletin, v. 107 , p. $396-406$.

Lugn, A.L., 1939, Nebraska in relation to the problems of Pleistocene stratigraphy: American Journal of Science, v. 237 , p. $851-884$.

Lugn, A.L., 1968, The origin of loesses and their relation to the Great Plains in North America, in Schultz, C.B. and Frye, J.C., eds., Loess and related eolian deposits of the world: Lincoln, University of Nebraska Press, p. 139-182.

Maat, P.B., and Johnson, W.C., 1996, Thermoluminescence and new ${ }^{14} \mathrm{C}$ age estimates for late Quaternary loesses in southwestern Nebraska: Geomorphology, v. 17, p. 115-128, doi: 10.1016/0169-555X(95)00099-Q.

Madole, R.F., 1991a, Surficial geologic map of the Walden $30^{\prime} \times 60^{\prime}$ quadrangle, Jackson, Larimer, and Rout Counties, Colorado: U.S. Geological Survey Miscellaneous Investigations Series Map I-1824, scale $1: 100,000,1$ sheet.

Madole, R.F., 1991b, Surficial geologic map of the Steamboat Springs $30^{\prime} \times 60^{\prime}$ quadrangle, Grand, Jackson, and Routt Counties, Colorado: U.S. Geological Survey Miscellaneous Investigations Series Map I-1825, scale $1: 100,000,1$ sheet.

Madole, R.F., VanSistine, D., and Michael, J.A., 1998, Glaciation in the Upper Platte River Drainage Basin, Colorado: U.S. Geological Survey Geologic Investigations Series Map I-2644, 1:333,333, 1 sheet

Mahowald, N., Kohfeld, K., Hansson, M., Balkanski, Y., Harrison, S.P., Prentice, I.C., Schulz, M., and Rodhe, H., 1999, Dust sources and deposition during the last glacial maximum and current climate: A comparison of model results with paleodata from ice cores and marine sediments: Journal of Geophysical Research, v. 104 p. 15,895-15,916, doi: 10.1029/1999JD900084.

Mahowald, N.M., Muhs, D.R., Levis, S., Rasch, P.J., Yoshioka, M., Zender, C.S., and Luo, C., 2006, Change in atmospheric mineral aerosols in response to climate Last glacial period, preindustrial, modern, and doubled carbon dioxide climates: Journal of Geophysical Research, v. 111, doi: 10.1029/2005JD006653.

Mandel, R., and Bettis, E.A., III, 1995, Late Quaternary landscape evolution and stratigraphy in eastern Nebraska, in Diffendal, R.F., Jr., and Flowerday, C.A., eds., Geologic field trips in Nebraska and adjacent parts of Kansas and South Dakota: Lincoln, University of Nebraska, Institute of Agriculture and Natural
Resources, Conservation and Survey Division Guidebook 10, p. 77-90.

Martin, J.E., Sawyer, J.F., Fahrenbach, M.D., Tomhave, D.W., and Schulz, L.D., 2004, Geologic map of South Dakota: South Dakota Department of Environment and Natural Resources, Geological Survey General Map 10 , scale $1: 500,000,1$ sheet

Mason, J.A., 2001, Transport direction of Peoria Loess in Nebraska and implications for loess sources on the central Great Plains: Quaternary Research, v. 56, p. 79-86, doi: 10.1006/qres.2001.2250.

Mason, J.A., and Kuzila, M.S., 2000, Episodic Holocene loess deposition in central Nebraska: Quaternary International, v. 67 , p. 119-131, doi: $10.1016 /$ S1040-6182(00)00013-6.

Mason, J.A., Nater, E.A., Zanner, C.W., and Bell, J.C., 1999 A new model of topographic effects on the distribution of loess: Geomorphology, v. 28, p. 223-236, doi: 10.1016/S0169-555X(98)00112-3.

Mason, J.A., Jacobs, P.M., Hanson, P.R., Miao, X., and Goble, R.J., 2003a, Sources and paleoclimatic significance of Holocene Bignell Loess, central Great Plains, USA: Quaternary Research, v. 60, p. 330-339, doi: 10.1016/j.yqres.2003.07.005

Mason, J.A., Jacobs, P.M., Greene, R.S.B., and Nettleton, W.D., 2003b, Sedimentary aggregates in the Peoria Loess of Nebraska, USA: CATENA, v. 53, p. 377-397, doi: 10.1016/S0341-8162(03)00073-0.

Mason, J.A., Joeckel, R.M., and Bettis, E.A., III, 2007, Middle to Late Pleistocene loess record in eastern Nebraska, USA, and implications for the unique nature of Oxygen Isotope Stage 2: Quaternary Science Reviews, v. 26 , p. 773-792, doi: 10.1016/j.quascirev.2006.10.007.

May, D.W., Swinehart, J.B., Loope, D., and Souders, V., 1995, Late Quaternary fluvial and eolian sediments: Loup River Basin and the Nebraska Sand Hills, in Diffendal, R.F., Jr., and Flowerday, C.A., eds., Geologic field trips in Nebraska and adjacent parts of Kansas and South Dakota: Lincoln, University of Nebraska, Institute of Agriculture and Natural Resources, Conservation and Survey Division Guidebook 10, p. 13-31.

McGeehin, J., Burr, G.S., Jull, A.J.T, Reines, D Gosse, J., Davis, P.T., Muhs, D., and Southon, J.R., 2001, Steppedcombustion ${ }^{14} \mathrm{C}$ dating of sediment: A comparison with established techniques: Radiocarbon, v. 43, p. 255-261.

McTainsh, G., 1987, Desert loess in northern Nigeria: Zeitschrift für Geomorphologie, v. 31, p. 145-165.

McTainsh, G.H., 1989, Quaternary aeolian dust processes and sediments in the Australian region: Quaternary Science Reviews, v. 8, p. 235-253, doi: 10.1016/0277-3791(89)90039-5

Mears, B., Jr., 2001, Glacial records in the Medicine Bow Mountains and Sierra Madre of southern Wyoming and adjacent Colorado, with a Traveler's guide to their sites: Public Information Circular-Geological Survey of Wyoming Report 41, $26 \mathrm{p}$

Miao, X., Mason, J.A., Goble, R.J., and Hanson, P.R. 2005 , Loess record of dry climate and aeolian activity in the early- to mid-Holocene, central Great Plains, North America: The Holocene, v. 15, p. 339-346, doi: 10.1191/0959683605hl805rp.

Miao, X., Mason, J.A., Swinehart, J.B., Loope, D.B., Hanson, P.R., Goble, R.J., and Liu, X., 2007, A 10,000 year record of dune activity, dust storms, and severe drought in the central Great Plains: Geology, v. 35, p. 119-122, doi: 10.1130/G23133A.1.

Muhs, D.R., 2004, Mineralogical maturity in dunefields of North America, Africa and Australia: Geomorphology, v. 59, p. 247-269, doi: 10.1016/j.geomorph.2003.07.020.

Muhs, D.R., and Bettis, E.A., III, 2000, Geochemical variations in Peoria Loess of western Iowa indicate paleowinds of midcontinental North America during last glaciation: Quaternary Research, v. 53, p. 49-61, doi: 10.1006/qres.1999.2090.

Muhs, D.R., and Bettis, E.A., III, 2003, Quaternary loesspaleosol sequences as examples of climate-driven sedimentary extremes, in Chan, M.A., and Archer, A.W., eds., Extreme depositional environments: Mega end members in geologic time: Geological Society of America Special Paper 370, p. 53-74.

Muhs, D.R., Stafford, T.W., Cowherd, S.D., Mahan, S.A., Kihl, R., Maat, P.B., Bush, C.A., and Nehring, J., 1996, 
Origin of the late Quaternary dune fields of northeastern Colorado: Geomorphology, v. 17, p. 129-149, doi 10.1016/0169-555X(95)00100-J.

Muhs, D.R., Stafford, T.W., Jr., Swinehart, J.B., Cowherd, S.D., Mahan, S.A., Bush, C.A., Madole, R.F., and Maat, P.B., 1997, Late Holocene eolian activity in the mineralogically mature Nebraska Sand Hills: Quaternary Research, v. 48, p. 162-176, doi: 10.1006/qres.1997.1913.

Muhs, D.R., Aleinikoff, J.N., Stafford, T.W., Jr., Kihl, R., Been, J., Mahan, S.A., and Cowherd, S., 1999, Late Quaternary loess in northeastern Colorado: Part I-Age and paleoclimatic significance: Geological Society of America Bulletin, v. 111, p. 1861-1875, doi: 10.1130/ 0016-7606(1999)111<1861:LQLINC >2.3.CO;2.

Muhs, D.R., Swinehart, J.B., Loope, D.B., Been, J., Mahan, S.A., and Bush, C.A., 2000, Geochemical evidence for an eolian sand dam across the North and South Platte Rivers in Nebraska: Quaternary Research, v. 53 , p. 214-222, doi: 10.1006/qres.1999.2104.

Muhs, D.R., Bettis, E.A., III, Been, J., and McGeehin, J. 2001, Impact of climate and parent material on chemical weathering in loess-derived soils of the Mississippi River Valley: Soil Science Society of America Journal, v. 65 , p. $1761-1777$.

Muhs, D.R., Ager, T.A., Bettis, E.A., III, McGeehin, J., Been, J.M., Begét, J.E., Pavich, M.J., Stafford, T.W., Jr., and Pinney, D., 2003a, Stratigraphy and paleoclimatic significance of late Quaternary loess-paleosol sequences of the last interglacial-glacial cycle in central Alaska: Quaternary Science Reviews, v. 22, p. 1947-1986, doi 10.1016/S0277-3791(03)00167-7.

Muhs, D.R., Ager, T.A., Been, J., Bradbury, J.P., and Dean, W.E., 2003b, A late Quaternary record of eolian silt deposition in a maar lake, St. Michael Island, western Alaska: Quaternary Research, v. 60, p. 110-122, doi 10.1016/S0033-5894(03)00062-0.

Myers, M., 1993, A Pliocene eolian sand sheet beneath the Nebraska Sand Hills [M.S. thesis]: Lincoln, University of Nebraska, $122 \mathrm{p}$

Nahon, D., and Trompette, R., 1982, Origin of siltstones: Glacial grinding versus weathering: Sedimentology, v. 29 , p. $25-35$, doi: $10.1111 /$ j.1365-3091.1982 tb01706.x.

Parker, R.L., and Fleischer, M., 1968, Geochemistry of niobium and tantalum: U.S. Geological Survey Professional Paper 612, $43 \mathrm{p}$.

Porter, S.C., 2001, Chinese loess record of monsoon climate during the last glacial-interglacial cycle: EarthScience Reviews, v. 54, p. 115-128, doi: 10.1016/ S0012-8252(01)00043-5.

Pye, K., 1983, Formation of quartz silt during humid tropical weathering of dune sands: Sedimentary Geology, v. 34 p. 267-282, doi: 10.1016/0037-0738(83)90050-7.

Pye, K., 1987, Aeolian dust and dust deposits: San Diego, Academic Press, 334 p.

Pye, K., 1995, The nature, origin and accumulation of loess: Quaternary Science Reviews, v. 14, p. 653-657, doi: 10.1016/0277-3791(95)00047-X.

Pye, K., Winspear, N.R., and Zhou, L.P., 1995, Thermoluminescence ages of loess and associated sediments in central Nebraska, USA: Palaeogeography, Palaeoclimatology, Palaeoecology, v. 118 , p. $73-87$, doi 10.1016/0031-0182(94)00134-T.

Reed, E.C., 1968, Loess deposition in Nebraska, in Schultz, C.B., and Frye, J.C., eds., Loess and related eolian deposits of the world: Lincoln, University of Nebraska Press, p. 139-182.

Roberts, H.M., Muhs, D.R., Wintle, A.G., Duller, G.A.T. and Bettis, E.A., III, 2003, Unprecedented last glacial mass accumulation rates determined by luminescence dating of loess from western Nebraska: Quaternary Research, v. 59, p. 411-419, doi: 10.1016/ S0033-5894(03)00040-1.

Rousseau, D.-D., Antoine, P., Kunesch, S., Hatté, C., Rossignol, J., Packman, S., Lang, A., and Gauthier, C., 2007, Evidence of cyclic dust deposition in the US Great Plains during the last deglaciation from the high-resolution analysis of the Peoria Loess in the Eustis sequence (Nebraska, USA): Earth and Planetary Science Letters, v. 262 , p. $159-174$, doi: $10.1016 / j$. eps1.2007.07.016.

Ruhe, R.V., 1969, Quaternary landscapes in Iowa: Ames, Iowa State University Press, $255 \mathrm{p}$

Ruhe, R.V., Miller, G.A., and Vreeken, V.J., 1971, Paleosols, loess sedimentation and soil stratigraphy, in Yaalon, D.H., ed., Paleopedology-Origin, nature and dating of paleosols: Jerusalem, Israel Universities Press, p. $41-59$.

Sato, Y., and Denson, N.M., 1967, Volcanism and tectonism as reflected by the distribution of nonopaque heavy minerals in some Tertiary rocks of Wyoming and adjacent states: U.S. Geological Survey Professional Pape 575-C, p. C42-C54.

Schultz, C.B., and Stout, T.M., 1945, Pleistocene loess deposits of Nebraska: American Journal of Science, v. 243 , p. $231-244$

Schultz, L.G., Tourtelot, H.A., Gill, J.R., and Boerngen, J.G., 1980, Composition and properties of the Pierre Shale and equivalent rocks, northern Great Plains Region: U.S. Geological Survey Professional Paper 1064-B, $114 \mathrm{p}$

Scott, G.R., 1978, Map Showing Geology, Structure, and Oi and Gas Fields in the Sterling $1^{\circ} \times 2^{\circ}$ Quadrangle, Colorado, Nebraska, and Kansas: U.S. Geological Survey Miscellaneous Investigations Series Map 1092, scale $1: 250,000,2$ sheets

Shilts, W.W., 1993, Geological Survey of Canada's contributions to understanding the composition of glacial sediments: Canadian Journal of Earth Sciences, v. 30, p. 333-353.

Smalley, I.J., 1966, The properties of glacial loess and the formation of loess deposits: Journal of Sedimentary Petrology, v. 36, p. 669-676.

Smalley, I.J., 1995, Making the material: The formation of silt-sized primary mineral particles for loess deposits: Quaternary Science Reviews, v. 14, p. 645-651, doi 10.1016/0277-3791(95)00046-1.

Smalley, I.J., and Vita-Finzi, C., 1968, The formation of fine particles in sandy deserts and the nature of 'desert' loess: Journal of Sedimentary Petrology, v. 38, p. 766-774.

Smalley, I.J., and Krinsley, D.H., 1978, Loess deposits associated with deserts: CATENA, v. 5, p. 53-66, doi: 10.1016/S0341-8162(78)80006-X.

Smith, B.J., Wright, J.S., and Whalley, W.B., 2002, Sources of non-glacial, loess-size quartz silt and the origins of "desert loess": Earth-Science Reviews, v. 59, p. 1-26, doi: 10.1016/S0012-8252(02)00066-1.

Swineford, A., and Frye, J.C., 1951, Petrography of the Peoria Loess in Kansas: Journal of Geology, v. 59, p. 306-322.
Swinehart, J.B., Souders, V.L., DeGraw, H.M., and Diffendal, R.F., Jr., 1985, Cenozoic paleogeography of western Nebraska, in Flores, R.M., and Kaplan, S.S., eds., Cenozoic paleogeography of west-central United States: Denver, Society of Economic Paleontologists and Mineralogists, Rocky Mountain Section, p. 209-229.

Swinehart, J.B., Dreeszen, V.H., Richmond, G.M., Tipton, M.J., Bretz, R., Steece, F.V., Hallberg, G.R., and Goebel, J.E., 1994a, Quaternary geologic map of the Platte River $4^{\circ} \times 6^{\circ}$ quadrangle, United States: U.S. Geological Survey Miscellaneous Investigations Series Map I-1420 (NK-14), scale 1:1,000,000, 1 sheet.

Swinehart, J.B., Loope, D., Ponte, M., Mason, J., Helland, P., and Kim, N., 1994b, Paleoenvironments of the Nebraska Sand Hills: SEPM (Society for Sedimentary Geology), Midcontinent Section, Field Trip Guidebook: Lincoln, University of Nebraska, $40 \mathrm{p}$.

Tsoar, H., and Pye, K., 1987, Dust transport and the question of desert loess formation: Sedimentology, v. 34, p. 139-153, doi: 10.1111/j.1365-3091.1987.tb00566.x.

Wang, H., Hughes, R.E., Steele, J.D., Lepley, S.W., and Tian, J., 2003, Correlation of climate cycles in middle Mississippi Valley loess and Greenland ice: Geology, v. 31, p. 179-182, doi: 10.1130/0091-7613(2003)031< 0179: $\mathrm{COCCIM}>2.0 . \mathrm{CO} ; 2$

Whalley, W.B., Marshall, J.R., and Smith, B.J., 1982, Origin of desert loess from some experimental observations: Nature, v. 300, p. 433-435, doi: 10.1038/300433a0.

Winspear, N.R., and Pye, K., 1995, Textural, geochemical and mineralogical evidence for the origin of Peoria loess in central and southern Nebraska, USA: Earth Surface Processes and Landforms, v. 20, p. 735-745, doi: 10.1002/esp.3290200805.

Wright, H.E., Jr., 1970, Vegetational history of the Central Plains, in Dort, W., Jr., and Jones, J.K., Jr., eds., Pleistocene and Recent environments of the Central Great Plains: Lawrence, University of Kansas, Department of Geology Special Publication, p. 157-172.

Wright, J.S., 2001a, "Desert" loess versus "glacial" loess: Quartz silt formation, source areas and sediment pathways in the formation of loess deposits: Geomorphology, v. 36, p. 231-256, doi: 10.1016/S0169$555 \mathrm{X}(00) 00060-\mathrm{X}$

Wright, J., 2001b, Making loess-sized quartz silt: Data from laboratory simulations and implications for sediment transport pathways and the formation of 'desert' loess deposits associated with the Sahara: Quaternary International, v. $76-77$, p. 7-19, doi: $10.1016 /$ S1040-6182(00)00085-9.

Wright, J., Smith, B., and Whalley, B., 1998, Mechanisms of loess-sized quartz silt production and their relative effectiveness: Laboratory simulations: Geomorphology, v. 23, p. 15-34, doi: 10.1016/S0169-555X(97)00084-6.

Zárate, M., and Blasi, A., 1993, Late Pleistocene-Holocene eolian deposits of the southern Buenos Aires Province, Argentina: A preliminary model: Quaternary International, v. 17, p. 15-20, doi: 10.1016/1040-6182(93) 90075-Q

ManusCRiPT ReCEIVEd 12 March 2007

ReVised Manuscript Received 2 January 2008

MANUSCRIPT ACCEPTED 4 JANUARY 2008

Printed in the USA 